\title{
THE LEVEL OF EFFICIENCY AND THE NEED FOR THE INFLUENCE OF SOCIAL SCIENCES ON THE DEVELOPMENT OF MODERN CIVILIZATION
}

Collective monograph

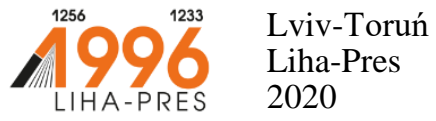




\section{Reviewers:}

Prof. nadzw., dr hab. Stanistaw Kunikowski, Rektor of Cuiavian University in Wloclawek (Republic of Poland);

Prof. dr hab. Joanna Marszałek-Kawa, Uniwersytet Mikołaja Kopernika w Toruniu / Nicolaus Copernicus University (Republic of Poland).

The level of efficiency and the need for the influence of social sciences on the development of modern civilization : collective monograph / K. S. Brenzovych, Yu. O. Ostapets, M. M. Palinchak, M. I. Tsalan, etc. - Lviv-Toruń : Liha-Pres, 2020. - 100 p.

ISBN 978-966-397-220-6

\section{SENSE} Liha-Pres is an international publishing house which belongs to the category "C" according to the classification of Research School for Socio-Economic and Natural Sciences of the Environment (SENSE) [isn: 3943, 1705, 1704, 1703, 1702, 1701; prefixMetCode: 978966397]. Official website www.sense.nl. 


\section{CONTENTS}

CHANGES IN FOREIGN TRADE POLICIES:

TRANSITION FROM FREE TRADE TO NEO-PROTECTIONISM

Brenzovych K. S.

PARTY SYSTEM OF UKRAINE: CHARACTERISTICS

OF THE MAIN PERIODS OF DEVELOPMENT (1991-2019)

Ostapets Yu. O

FORMATION OF "INFOSTAT UKRAINE-POLAND"

TRANSBOUNDARY CLUSTER - IMPORTANT FACTORS

OF PROGRESSION AND PERIFERATIONS

OF POLAND-SLOVAK-UKRAINIAN BORDER

Palinchak M. M. 38

ACTUAL DIRECTIONS OF STATE-OWNED ENTERPRISES

COMPETITIVENESS ENSURING

Tsalan M. I.

60

POLITICAL DISCOURSE IN A TRANSITIONAL SOCIETY:

BETWEEN THE SCYLLA OF ANARCHY

AND THE CHARYBDIS OF TYRANNY

Yakovlev D. V., Yeremenko O. M .74 



\title{
CHANGES IN FOREIGN TRADE POLICIES: TRANSITION FROM FREE TRADE TO NEO-PROTECTIONISM
}

\author{
Brenzovych K. S.
}

\section{INTRODUCTION}

The current stage of international economic relations is characterized by growing competition between national economies, mainly in the sphere of international trade. In the aftermath of the Second World War, governments of the Western world have united their efforts in the military, political and economic struggle against the main competitor - the Soviet Union, and have succeeded in this thanks to mutual assistance in international trade. Now, and especially after the world crisis of 2008, the things have changed. Developed countries of the world that defended the ideas of free trade in the second half of the 20th century are now increasingly using a wide range of tools to protect their markets from foreign competition, especially in relation to new industrialized countries.

Against the backdrop of the staggering growth dynamics of China and other emerging industrialized nations, there is a widespread question in academia about the future role of advanced "western" economies in the world trading system. China is firmly ahead of the US in foreign trade in goods, though, according to the Global Trade Alert, it is also the country most suffering from protectionist measures implemented by other countries in the world. In this regard, the study of changes in the trade policies of developed countries, including in the context of the opposition of emerging democracies to the emerging economies of transition, is a pressing issue for modern international economic relations.

\section{Theoretical and organizational principles of foreign trade regulation}

The regulation of foreign trade is carried out at national, international and global levels. At the national level, it is the implementation of the foreign trade policy of the countries as a component of the foreign economic policy of the state. At the international level, regulation of trade is carried out through economic integration mechanisms. The most common is the creation of free trade and preferential trade zones, whereby their members, by providing mutual advantages in trade with each other in comparison with third countries, are defending their own economic interests. At the global level, trade regulation is 
primarily carried out by the World Trade Organization (WTO) and, to a lesser extent, by UN Conference on Trade and Development (UNCTAD).

The mechanism of state regulation of foreign trade is a set of various forms, legal, economic, administrative methods and instruments that interact and complement each other and perform the functions of restraining and stimulating foreign trade. Legal methods are reflected in a system of legislative framework that regulates relations between entities, establishing an institutional structure, parts of which have certain rights, tasks and spheres of activity. Economic methods are manifested through the system of indirect influence on the decision-making by the subjects of foreign economic activity. Administrative methods supplement the above mentioned methods with the aim of promptly regulating foreign economic activity and resolving contradictions between its subjects.

State regulation of foreign economic activity is carried out using tariff (economic) and non-tariff (organizational and administrative) methods. With the help of tariff methods (duties and tariff quotas), a protective (protectionist) function is implemented (support of national producers and exporters), fiscal (receipt to the state budget from customs payments) and balancing (avoiding unwanted imports or exports). The effects of the application of customs tariff measures - duties and tariff quotas, depend primarily on the size of the state's economy. The imposition of a duty by a large economy (large means having such a share in global consumption of a good, that a reduction in imports may lead to a surplus of goods in the world market and, consequently, a decrease in its price), is likely to have a more positive impact on such an economy. The introduction of a duty by a small economy leads to a major drawback - a decline in the well-being of its citizens and inefficient use of resources because of the state support for inefficient production. In the medium term a deterioration of relations between partners and trade wars may occur.

Non-tariff (organizational and administrative) methods of regulating foreign economic activity are a restrictive and prohibitive measures impeding the penetration of foreign goods and services on the domestic market of the country. Non-tariff measures are considered as a hidden protectionism, having the character of administrative regulation of foreign economic activity. The purpose of non-tariff regulation of foreign economic activity is to protect the national economy, environment, improve public health, morality, religion and provide national security ${ }^{1}$. However, the mentioned purposes are showing the official excuse, while the real objective of their implementation is to provide obstacles to foreign producers on their way to national market.

\footnotetext{
${ }^{1}$ Міжнародна економіка: підручник. Київ: Центр навчальної літератури, 2006. 224 с.
} 
It is now believed that there are two opposite approaches to regulating foreign trade at the level of national economy (forms of foreign trade) protectionism and free trade (liberalism). However, they are rarely used in pure form in modern times, so most counties use combinations of protective and liberalizing measures.

Protectionism as a state policy for influencing foreign trade, was the main tenet of mercantilism, the dominant doctrine in the European economic thought of 17-18 century. It is a doctrine in which the existing world is regarded in statics, and the wealth of nations as a fixed phenomenon at all times. Therefore, his adherents (T. Maine, A. Serra, A. Moncretien) believed that the growth of the welfare of one country is only possible by redistribution of existing wealth, that is, due to impoverishment of another country. Mercantilists associated wealth with precious metals (gold and silver) and believed that the country was richer if it had a large amount of precious metals. Accordingly, since the main source of gold inflow is exports, it is necessary to avoid in any way the excess of imports over exports, to prevent leakage. Generally speaking, protectionist policy is to support national exporters through import tariff and non-tariff instruments that discriminate against foreign producers.

The recognition of the fact that protectionism as the theoretical basis of policies is harmful for the global economy, came in the second half of the 20th century, However the elements of this doctrine are still used in modern times. According to A.V. Kelichavy, the use of protectionist methods usually has a short-term positive effect. Counter measures, which may be used by trading partner countries as a respond, may undemine export opportunities and may cause damage to the national economy that will exceed the benefits of protective measures. In the long run, a government policy of protectionism, in the belief of the scientist, will be effective in two cases: in the presence of effective competition in the internal market or in the case of temporary nature of protectionism. In support of the first thesis, the author cites the example of Japan, in which, such industries as automotive, steel industry, machine tool production, electrical industry due to the fierce competition in the domestic market have become the most competitive in the world market ${ }^{2}$.

Nowadays, the economic policy of democratic economies is based mainly on the principles of comparative advantage formulated by D. Ricardo, with the idea of free trade in the core. According to the supporters of free trade, international trade is mutually beneficial if it is based on the use of the relative advantages of countries. They believe that state intervention in the form of restrictions on imports and artificial support for exports is harmful for national

${ }^{2}$ Келічавий А.В. Політика протекціонізму як фактор підвищення конкурентоспроможності економіки. Ефективна економіка. 2007. № 6. URL: http://www.economy.nayka.com.ua/ ?op=1\&z=3133 (дата звернення: 5.10.2019) 
and global economy. The main function of the state under free trade policy is to create an organizational and legal framework for the effective operation of market forces of supply and demand.

Table 1 analyzes the main advantages and threats of applying two approaches to regulating trade in states.

Table 1

Advantages and disadvantages of protectionism and free trade

\begin{tabular}{|c|c|c|}
\hline & Protectionism & Free trade \\
\hline 1 & 2 & 3 \\
\hline \multirow{6}{*}{ 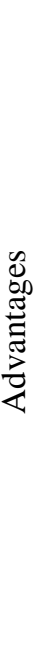 } & $\begin{array}{l}\text { Increase in revenues of the state } \\
\text { budget }\end{array}$ & $\begin{array}{l}\text { Effective use of economic } \\
\text { resources }\end{array}$ \\
\hline & $\begin{array}{l}\text { Support of emerging sectors of the } \\
\text { country's economy }\end{array}$ & $\begin{array}{l}\text { Deepening competition and } \\
\text { reducing monopolism }\end{array}$ \\
\hline & Increasing the employment rate & $\begin{array}{l}\text { Improving the well-being of } \\
\text { citizens }\end{array}$ \\
\hline & 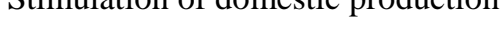 & \\
\hline & Reduction of imports and trade & between countries \\
\hline & & $\begin{array}{l}\text { Activation of innovative } \\
\text { development of economy, } \\
\text { dissemination of achievements of } \\
\text { scientific and technological } \\
\text { progress }\end{array}$ \\
\hline \multirow{5}{*}{ 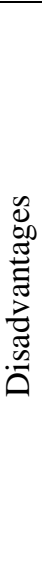 } & $\begin{array}{l}\text { Exacerbation of economic and } \\
\text { political contradictions between } \\
\text { countries }\end{array}$ & $\begin{array}{l}\text { Over-dependence of countries due } \\
\text { to narrow specialization }\end{array}$ \\
\hline & $\begin{array}{l}\text { Economic isolation from other } \\
\text { countries }\end{array}$ & $\begin{array}{l}\text { Loss of national production that is } \\
\text { not able to compete with imported } \\
\text { products }\end{array}$ \\
\hline & $\begin{array}{l}\text { Favorable conditions for the } \\
\text { development of internal } \\
\text { monopolies }\end{array}$ & $\begin{array}{l}\text { Increasing social tension through } \\
\text { job cuts in non-competitive } \\
\text { industries }\end{array}$ \\
\hline & Decrease of welfare of citizens & Possible increase of trade deficit \\
\hline & $\begin{array}{l}\text { Trade wars, deterioration of } \\
\text { relations with partners }\end{array}$ & \\
\hline
\end{tabular}


Table 1 (continued)

\begin{tabular}{|c|c|c|}
\hline 1 & 2 & 3 \\
\hline 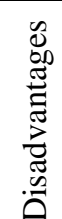 & $\begin{array}{l}\text { Lag in scientific and technical } \\
\text { development } \\
\text { Increasing the level of shadowing } \\
\text { of the economy (illegal imports) }\end{array}$ & \\
\hline
\end{tabular}

Developed using data from ${ }^{3,4,5}$

The countries of the world are still using different arguments and justifications to support protectionism such as the need to promote the development of new industries (called "baby industries"), to support existing industries or to fulfill social functions of government (reduce unemployment), to promote domestic production, and to eliminate overproduction, to decrease the dependence on imports of scarce goods and to diversificate national economy. Free trade promotes resource efficiency due to specialization, brings national economies closer, and promotes overall consumer well-being.

The term "neo-protectionism" is commonly used to denote a new trend of modern policies aimed to protect national markets, a phenomenon that encompasses modern, more sophisticated measures that enable states to pursue national interests in international trade. States are particularly active in "hidden" protectionism, which involves the application of non-tariff, hidden measures to regulate export-import transactions (technical requirements and barriers, internal taxes and fees, financial support for exporters, etc.).

The above mentioned instruments of influence on international trade are essentially national instruments, since the decision on their introduction is made at the level of state authorities. However, if the economy of the country is open (and most economies are), and is actively integrating into the world economy, then such measures are implemented and canceled under the close supervision of international organizations, whose activities are aimed at ensuring fair conditions for participation in international trade and mutually beneficial partnership. Such organizations, in particular, include the World Trade Organization.

${ }^{3}$ Козак Ю. Г. Міжнародна торгівля: навч.посібник. Київ: Центр учбової літератури, 2015. $272 \mathrm{c}$.

${ }^{4}$ Келічавий А.В. Політика протекціонізму як фактор підвищення конкурентоспроможності економіки. Ефективна економіка. 2007. № 6. URL: http://www.economy.nayka.com.ua/ ?op=1\&z=3133 (дата звернення: 6.10.2019)

${ }^{5}$ Баєва О.І. Теоретичні підходи до оцінки протекціонізму в міжнародній торгівельній практиці. Економіка і суспільство. 2018. Вип.16. C. 20-23. URL: http://economyandsociety.in.ua/ journal/16_ukr/4.pdf (дата звернення: 6.10.2019) 
World Trade Organization was founded on 1 January 1995 on the base of GATT (General Agreement on Trade and Tariffs). From 1948 to 1994 the GATT provided the rules for much of world trade and presided over periods that saw some of the highest growth rates in international commerce. It seemed well established but throughout those 47 years, it was a provisional agreement and organization. The WTO's creation on 1 January 1995 marked the biggest reform of international trade since the end of the Second World War. Whereas the GATT mainly dealt with trade in goods, the WTO and its agreements also cover trade in services and intellectual property. The birth of the WTO also created new procedures for the settlement of disputes ${ }^{6}$.

Today, the WTO is a powerful and influential international entity capable of fulfilling the functions of global economic regulation. WTO membership has become almost a prerequisite for any country seeking to integrate into the world economy. The organization is now a member of 164 countries, accounting for more than $98 \%$ of world trade.

The work of the WTO is based on the principle of bilateral negotiations between members in order to open their markets. WTO members, while formulating requirements for candidate countries for access to their markets, can defend the interests of their own businesses, thus protecting their own production and jobs. WTO membership attracts countries that agree to defend national interests in trade through mutually beneficial, yet controlled, cooperation.

However, some scholars increasingly question the role of the WTO in ensuring fair conditions for international trade. Yes, N.I. Patyka argues that it is not necessary to consider that the codes and conventions of this reputable organization are perfect and acceptable for all, without exception, countries, both developed and those who have just embarked on the path of market transformation, or overcoming deep social and economic crisis. On the one hand, a wide range of issues is being solved all the time with the help of the WTO, and on the other hand, new problems and contradictions are created in the relations between the countries ${ }^{7}$. Therefore, the issue of the realization of national interests in international trade should be considered comprehensively, taking into account the degree of influence of the most powerful economies in the world economy on the decisions of the supranational level and the ability of developing economies to assert their right to equality in international trade.

Interstate regulation takes an intermediate place between national and global levels of regulation. Recently, due to the lack of long-term progress in WTO trade dispute settlement, the rise of protectionist practices, some countries

\footnotetext{
${ }^{6}$ History of the multilateral trading system. The World Trade Organization website. URL: https://www.wto.org/english/thewto_e/history_e/ history_e.htm (Accessed 6 October 2019)

${ }^{7}$ Патика Н.I. СОТ і розвиток економік країн-нових членів. Економіка $і$ держава. 2012. № 4. С. 25-28 (дата звернення: 6.10.2019)
} 
have returned to an effective mechanism for promoting their trade interests, namely bilateral and multilateral free trade agreements. There was a sharp increase in regional trade agreements in the early 2000s, when it became clear that the Doha Round would not have the expected results. According to the WTO, more than 300 such agreements are in force today, although in 2003 there were half that number ${ }^{8}$. However, according to V.K. Matveyenko, the formation of different types of regional economic groups should not be regarded as a force that counteracts globalization. A certain amount of protectionism, which took place in the process of their formation, is inevitable. It allows developing the local economy at first, helps to increase the price competitiveness of products in both the domestic and foreign markets, and leads to active engagement in the world economic relations as both exporter and importer of goods and services ${ }^{9}$. Thanks to mutual liberalization within the integration, competition is intensified and efficiency and innovativeness of the enterprises belonging to it is increasing. Due to the mutual opening of markets within the group, the losses from the introduction of an external tariff are compensated. The competitiveness of products on the world market, beyond the grouping, is increasing.

\section{Practice of application of protective measures in foreign trade}

Today, most states have a flexible foreign trade policy that combines elements of protectionism and free trade; this is a prospect for the proper functioning of the state's foreign trade policy at the present stage. However, each country's choice of its own foreign trade policy model is determined mainly by the degree of competitiveness of its national economy and the state of its trade balance (export-import ratio) ${ }^{10}$.

Today, as noted by O.I. Bayeva, the policies of free trade and protectionism are connected. Developed countries not only increase the role of free trade, but also actively use harmful measures to protect and enhance the competitiveness of the national economy. All countries are using both tariff or non-tariff instruments in international trade practice. The countries began to protect their domestic market from external interference again ${ }^{11}$.

8 Regional trade agreements. URL: https://www.wto.org/english/tratop_e/region_e/ region_e.htm (Accessed 7 October 2019).

${ }^{9}$ Матвєєнко В. К. Економічна глобалізація та регіональна інтеграція - дві форми інтернаціоналізації світового господарства. Вісник соціально-економічних досліджень. 2013. Вип. 4. С. 282-287. URL: http://nbuv.gov.ua/_UJRN/Vsed_2013_4_45 (дата звернення: 7.10.2019).

10 Бондарчук Л.В., Гусак К.Ю. Шляхи удосконалення зовнішньоторговельної політики України. Науковий вісник УжНУ. Серія «Міжнародні економічні відносини та світове господарство». 2018. Вип. 19. Ч. 1. С. 31-34 (дата звернення: 7.10.2019)

11 Баєва O.I. Теоретичні підходи до оцінки протекціонізму в міжнародній торгівельній практиці. Економіка $i$ суспільство. 2018. Вип. 16. С. 20-23. URL: http://economyandsociety.in.ua/journal/16_ukr/4.pdf (дата звернення: 6.10.2019) 
Most experts in world economy and international trade relations, representatives of international economic institutions and informal economic groups agree that protectionism in the global economy is most detrimental to the state that is implementing such measures. The widespread use of protective measures is slowing global development and may be a step back in the path towards a free economy. However, all countries of the world today are more or less applying measures aimed at supporting domestic and discriminating against foreign manufacturers, preventing competitive products from entering the domestic markets. Such measures are common practice for countries with underdeveloped economies, mainly through the creation of free and preferential trade zones, and the introduction of discriminatory, mostly customs, measures against third countries.

Countries with high levels of economic development largely build their trade policies on a free trade basis and in accordance with the principles of the World Trade Organization. However, according to official statistics, in the period of exacerbation of global economic and political contradictions, this group of countries intensifies the application of customs tariff and non-tariff protection measures. In this context, the change in the US political leadership and the decision of Brinain to leave the EU are obviously important events in recent years that can substantially change the foreign trade strategies of developed economies and largely offset the more than 50 years of world trade liberalization achieved in the course of multilateral negotiations.

Political ideas of economic nationalism, both based on support of domestic producers and emphasizing the harmfulness of globalization, are gaining popularity in both Europe and the USA. Taking into account the slow recovery of the global economy from the global crisis, and the study of historical experience that shows the rise of protectionist stagnation in times of economic crisis, it can be assumed that the increased use of protective measures in foreign trade policies of developed countries, including the United States and most countries of the EU, is quite real.

Some economists are now predicting the end of an era of globalization, arguing that new protectionism is obvious and states are taking steps to privilege domestic industries. For example, the provision of open or hidden subsidies, export duties, and measures designed to prevent highly skilled foreign labor from entering the domestic labor market. Since the global financial crisis, almost every country in the world has been implementing measures aimed at protecting their domestic companies and complicating work for foreign businesses ${ }^{12}$.

12 2016-ий - Ренесанс протекціонізму. URL: http://www.dw.com/uk/2016-ий-ренесанспротекціонізму/а-36924555 (дата звернення: 7.10.2019) 
The increasing influence of the World Trade Organization on the processes of reducing the use of customs tariff instruments in foreign trade has significantly affected the average level of customs protection of most countries. The main mechanism for the implementation of the task of reducing customs protection was to link a tariff position, which is a country's commitment not to apply tariffs or other duties and fees at rates that exceed those duties and fees that were set during the negotiations. Such customs are called bonded customs duties.

According to the World Bank, the weighted average customs tariff has decreased from $35 \%$ in 1995 to $2.5 \%$ in 2017 . Duty rates have been reduced in almost all economies, in advanced economies to the most extent. The top 20 countries with the highest rates of duties does not include developed economies. Average tariff in developed countries is $4-5 \%$, remaining rather high for some developing countries. According to the WTO, this figure is about $5.2 \%$ for the EU (the average "weighted" tariff rate for the most favored nations), 3.4\% for the US, $4 \%$ for Canada and $4.2 \%$ for Japan, $4.5 \%$ for Ukraine ${ }^{13}$. For comparison, the same indicator of tariff protection of the national market of Zimbabwe is $17.5 \%$, Sudan $-21.5 \%$, North Korea $-13.7 \%$, Argentina - 13.6\%, India and Pakistan $-13.4 \%$. Thus, the active reduction of the level of customs protection of economies - mainly developed and transitional ones - was the main trend of the last 25-30 years. Two countries in the top 10 in Human Development Index ranking - Singapore and Hong Kong - are territories completely free of import duties ${ }^{14}$.

The downside of reducing customs protection was the intensification of non-tariff protectionism. Such instruments, which by their characteristics of influence on export-import flows belong to financial, quantitative, hidden, are applied by the countries of the world for regulation of foreign trade depending on strategic tasks of economic security of the state, needs of the internal market, tasks of transformation of structure of national economy and even geopolitical priorities.

According to Global Trade Alert research, the number of safeguards has steadily increased during 2009-2018. Figure 1 shows the dynamics of the application of foreign trade regulation measures across countries, including liberalizing and harmful measures. Countries' engagement in protectionist instruments has increased during the global crisis and has not stopped yet. Obviously, the financial crisis is a turning point in the modern regulation of international trade. The justified and seemingly temporary application of measures to support national producers under the global crisis has given impetus to the resurgence of protectionism.

\footnotetext{
${ }^{13}$ Tariff rate, applied, weighted mean, all products (\%). URL: https://data.worldbank.org/ indicator/tm.tax.mrch.wm.ar.zs (Accessed 8 October 2019).

14 Developed Countries List 2019. URL: http://worldpopulationreview.com/countries/ developed-countries/ (Accessed 8 October 2019).
} 
As it can be seen from the figure 1, the number of restrictive measures is almost 4 times higher than the number of liberalization ones. The overall reduction in liberalizing measures could be explained by the achievement of a certain maximum of the measures achieved (such as the European Union, which has introduced a significant number of promotion measures in the Eastern Partnership countries over the last few years). However, the simultaneous increase in protectionist measures (900 new measures in 2018, which is 3 times more than in the "crisis year" of 2009), indicates a reversal of threatening trends.

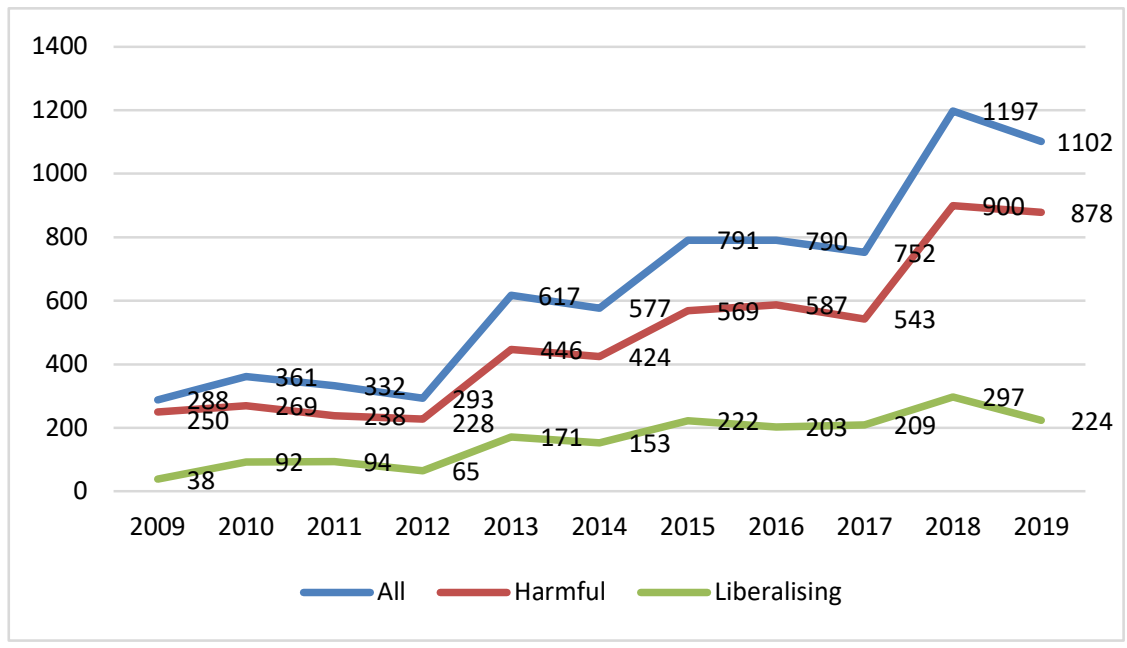

Figure 1.Total number of imposed trade interventions, 2009 - June-October 2019, by number $(2009-2019)^{15}$

Experts are already comparing the current period of state intervention in international trade with the events of the 1930s and 1980s, when there was a similar leap in the application of protectionist measures. The similarity of the motives in the application of such measures, according to scientists, justifies the use of the term "protectionism" in the modern international trade.

The top-5 countries according to the number of imposed harmful interventions since 2008 are the USA (751 new measures), India (526), Russia (386), Germany (376), the United Kingdom (321). The European Union is the absolute leader in the application of harmful measures. According to the same

15 Total number of implemented interventions since November 2008. Global trade alert. URL: https://www.globaltradealert.org/global_dynamics/day-to_1016/flow_all (Accessed 8 October 2019). 
organization, the world's leading economies are focusing their efforts primarily on protecting industries that specialize in metal, chemical, transportation, equipment and agricultural products. The figure 2 shows the activity of the countries of the world in the application of measures to protect national markets from foreign competitors (harmful interventions).

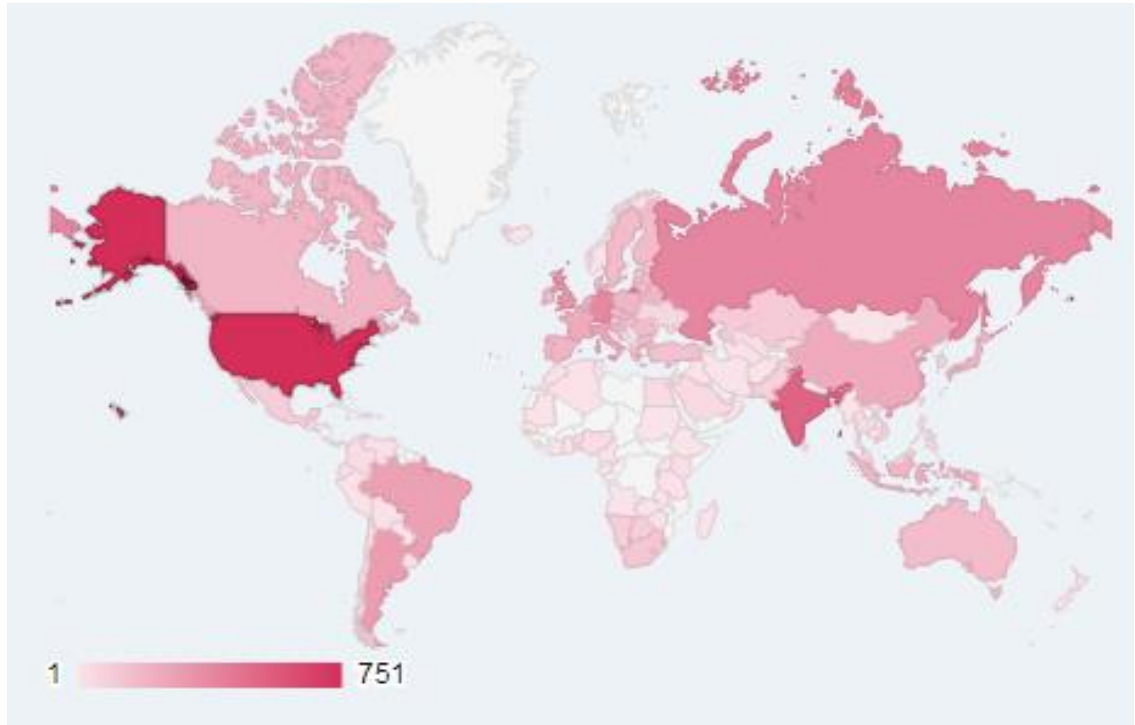

Figure 2. Harmful interventions implemented in foreign trade policy, by country contribution to interventions $(2008 \text { - October } 2019)^{16}$

Countries, which are the most affected by harmful interventions, include China (2419 measures were implemented against China by other countries of the world since 2008), Germany (1678), Italy (1551), France (1467), United States of America (1450) - Figure 3.

According to analysis of harmful interventions, imposed in 2018, 61\% of world goods exports competed against a foreign firm whose government makes available some type of financial inducement to export. Over $34 \%$ of world goods exports in 2018 faced other (non-export related) trade distortions when competing in third markets, suggesting that the cumulative scale of other trade distortions is significant. A fifth of world goods exports (20.9\%) competed in

16 Total number of implemented interventions since November 2008. Global trade alert. URL: https://www.globaltradealert.org/global_dynamics/day-to_1016/flow_all (Accessed 8 October 2019). 
foreign markets against a local firm that has been bailed out or received another form of (non-export related) financial largesse from the state ${ }^{17}$.

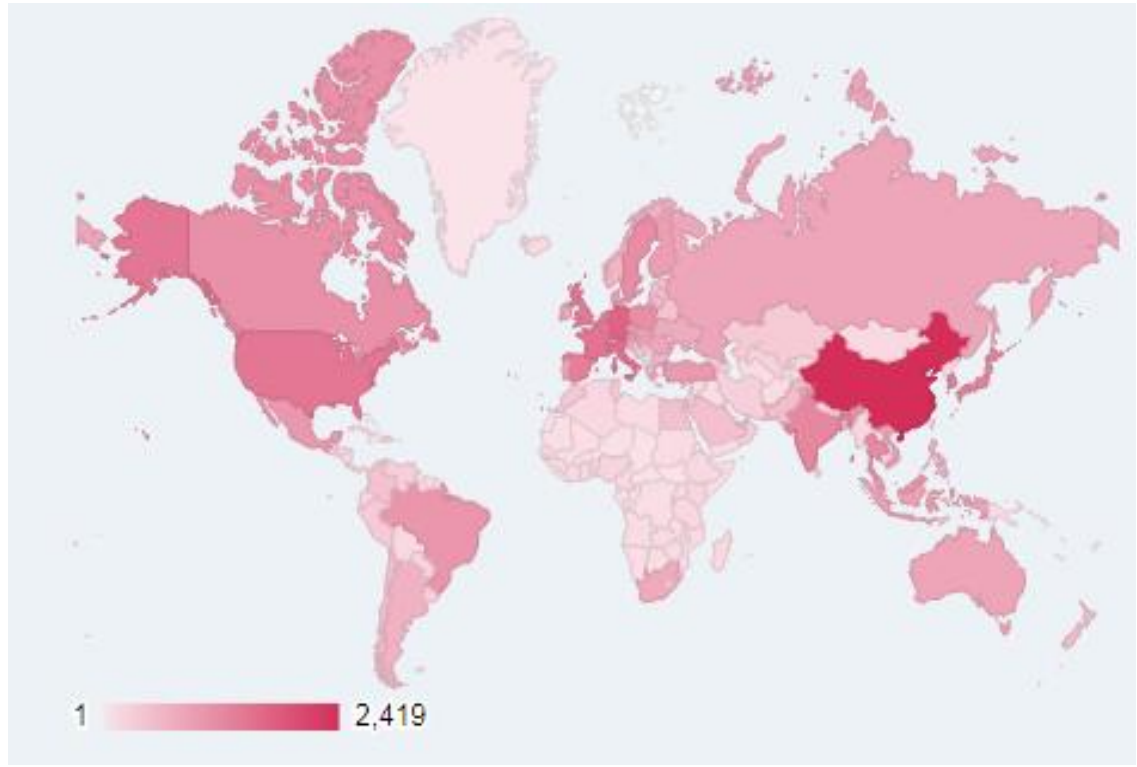

Figure 3. Countries, affected by trade interventions, by number of harmful interventions (2009 - October 2019) ${ }^{18}$

In the practice of foreign trade regulation, such protective measures as anti-dumping and countervailing duties, as well as technical measures (nontariff) - sanitary and phyto-sanitary standards, industry standards and product quality requirements, are frequently used too.

The introduction of measures, such as anti-dumping and countervailing duties is a legitimate procedure, foreseen by WTO, that gives a chance for the states to respond to the use of direct government subsidies used by foreign partners, or react to other types of financial assistance. Requirements for the content of local components is the most "popular" measure in the foreign trade policy of underdeveloped countries.

17 Protectionism, state discrimination, and international business since the onset of the Global Financial Crisis. ULR: https://www.globaltradealert.org/reports/46 (Accessed 8 October 2019).

18 Total number of implemented interventions since November 2008. Global trade alert. URL: https://www.globaltradealert.org/global_dynamics/day-to_1016/flow_all (Accessed 8 October 2019). 
Developed countries, thanks to their high level of specialization in finished products, quality standards, are able to use tools related to technical barriers. Their peculiarity is that the World Trade Organization does not prohibit such measures, since they do not directly target imports but place requirements for the standardization and certification of products entering the domestic markets. However, there is a practice of bilateral agreements between developed countries on mutual recognition of such requirements, which facilitates trade between countries with high levels of economic development, and "eliminates" the possibility of penetration into their markets of goods from the third (mostly underdeveloped) countries.

The EU technical regulation system is considered to be the most effective and successful example of removing technical barriers to trade (certainly this relates to trade among the EU countries). The European technical model is based on the principles of the New and Global approaches, first formulated in 1985 and 1989. In accordance with these principles, the essential requirements for product safety and quality are laid down in EU technical regulations and are binding, while harmonized EU standards are voluntary. At the same time, conformity of products to one of the harmonized EU standards (developed within the framework of technical regulations) is considered as a general satisfaction of the basic requirements stipulated by a technical regulation. Compliance with the requirements of the technical regulations is monitored through market surveillance rather than control of the production process.

The assessment of the industries and products covered by the harmful interventions, characterizes the overall interest in the trade of the countries, which are introducing such safeguards. Products of iron or steel, other fabricated metal products, motor vehicles, trailers \& semi-trailers; basic organic chemicals, cereals ate the top products that are the most protected by the countries. Sectors which are most often covered by liberalizing interventions include: instruments \& control equipment, except optical instruments, other special-purpose machinery \& parts, other general-purpose machinery \& parts, machinery for mining, quarrying \& construction; other electrical equipment $\&$ parts.

Table 2 provides a list of the most "protected" and most "opened" industries (commodity groups) of the world's leading economies (which can be classified as "large" in terms of impact on the global commodity environment). The protected sectors are those for which the country uses the most protective measures (harmful interventions). Accordingly, the sectors for which the country uses the most import-enhancing regulatory instruments have been identified as the most opened, or liberalized. 
The most protected and liberalized sectors of the top-10 economies of the world ${ }^{19}$

\begin{tabular}{|c|c|c|}
\hline $\begin{array}{c}\text { Country } \\
\text { contribution to } \\
\text { interventions }\end{array}$ & The most "protected" sectors & $\begin{array}{c}\text { The most "liberalized" } \\
\text { sectors }\end{array}$ \\
\hline 1 & 2 & 3 \\
\hline USA & $\begin{array}{l}\text { Basic iron \& steel, } \\
\text { Products of iron or steel; } \\
\text { Electrical energy; Other fabricated } \\
\text { metal products; Motor vehicles, } \\
\text { trailers \& semi-trailers; parts }\end{array}$ & $\begin{array}{l}\text { Wearing apparel, except fur } \\
\text { apparel; Made-up textile } \\
\text { articles; Domestic appliances } \\
\text { parts }\end{array}$ \\
\hline China & $\begin{array}{l}\text { Basic organic chemicals } \\
\text { Basic inorganic chemicals } \\
\text { Basic iron \& steel } \\
\text { Metal wastes or scraps } \\
\text { On-line content }\end{array}$ & $\begin{array}{l}\text { Basic inorganic chemicals n.e.c. } \\
\text { Other general-purpose } \\
\text { machinery \& parts } \\
\text { Other special-purpose } \\
\text { machinery \& parts } \\
\text { Basic organic chemicals } \\
\text { Petroleum oils \& oils of } \\
\text { bituminous materials, other } \\
\text { than crude }\end{array}$ \\
\hline Japan & $\begin{array}{l}\text { Motor vehicles, trailers \& semi- } \\
\text { trailers; parts } \\
\text { Engines \& turbines \& parts } \\
\text { Ships } \\
\text { Motor vehicle bodies; trailers \& parts } \\
\text { thereof } \\
\text { Petroleum oils \& oils of bituminous } \\
\text { materials, other than crude }\end{array}$ & $\begin{array}{l}\text { Basic organic chemicals } \\
\text { Prepared \& preserved fish, } \\
\text { crustaceans, mollusks } \\
\text { Carpets \& other textile floor } \\
\text { coverings } \\
\text { Forage; natural rubber; living } \\
\text { plants; raw vegetable } \\
\text { materials } \\
\text { Made-up textile articles }\end{array}$ \\
\hline Germany & $\begin{array}{l}\text { Aircraft \& spacecraft; parts } \\
\text { Fruits \& nuts } \\
\text { Prepared \& preserved fruits \& nuts } \\
\text { Vegetables } \\
\text { Basic organic chemicals }\end{array}$ & $\begin{array}{l}\text { Prepared \& preserved fruits \& } \\
\text { nuts } \\
\text { Fruits \& nuts } \\
\text { Vegetables } \\
\text { Basic organic chemicals } \\
\text { Meat \& meat products }\end{array}$ \\
\hline United Kingdom & $\begin{array}{l}\text { Fruits \& nuts } \\
\text { Prepared \& preserved fruits \& nuts } \\
\text { Vegetables } \\
\text { Basic organic chemicals } \\
\text { Products of iron or steel }\end{array}$ & $\begin{array}{l}\text { Fruits \& nuts } \\
\text { Prepared \& preserved fruits \& } \\
\text { nuts } \\
\text { Vegetables } \\
\text { Basic organic chemicals } \\
\text { Meat \& meat products }\end{array}$ \\
\hline
\end{tabular}

19 Countries. Global Trade alert. URL: https://www.globaltradealert.org/ countries (Accessed 8 October 2019). 
Table 2 (continued)

\begin{tabular}{|c|c|c|}
\hline 1 & 2 & 3 \\
\hline India & $\begin{array}{l}\text { Basic organic chemicals } \\
\text { Products of iron or steel } \\
\text { Basic inorganic chemicals n.e.c. } \\
\text { Wearing apparel, except fur apparel } \\
\text { Other fabricated metal products }\end{array}$ & \begin{tabular}{|l} 
Vegetables \\
Cereals \\
Grain mill products \\
Vegetable oils \\
Forage; natural rubber; living \\
plants; raw vegetable \\
materials \\
\end{tabular} \\
\hline France & $\begin{array}{l}\text { Fruits \& nuts } \\
\text { Prepared \& preserved fruits \& nuts } \\
\text { Vegetables } \\
\text { Basic organic chemicals } \\
\text { Chemical products n.e.c. }\end{array}$ & $\begin{array}{l}\text { Fruits \& nuts } \\
\text { Prepared \& preserved fruits \& } \\
\text { nuts } \\
\text { Vegetables } \\
\text { Basic organic chemicals } \\
\text { Cereals }\end{array}$ \\
\hline Italy & $\begin{array}{l}\text { Fruits \& nuts } \\
\text { Prepared \& preserved fruits \& nuts } \\
\text { Vegetables } \\
\text { Basic organic chemicals } \\
\text { Chemical products n.e.c. }\end{array}$ & $\begin{array}{l}\text { Prepared \& preserved fruits \& } \\
\text { nuts } \\
\text { Fruits \& nuts } \\
\text { Vegetables } \\
\text { Basic organic chemicals } \\
\text { Cereals }\end{array}$ \\
\hline Brazil & $\begin{array}{l}\text { Basic organic chemicals } \\
\text { Machinery for mining, quarrying \& } \\
\text { construction; parts } \\
\text { Other fabricated metal products } \\
\text { Motor vehicles, trailers \& semi- } \\
\text { trailers; parts } \\
\text { Electric motors, generators \& } \\
\text { transformers; parts }\end{array}$ & $\begin{array}{l}\text { Instruments \& control } \\
\text { equipment, except optical } \\
\text { instruments } \\
\text { Other special-purpose } \\
\text { machinery \& parts } \\
\text { Other electrical equipment \& } \\
\text { parts } \\
\text { Computing machinery \& parts } \\
\text { Other general-purpose } \\
\text { machinery \& parts }\end{array}$ \\
\hline Canada & $\begin{array}{l}\text { Products of iron or steel } \\
\text { Crude petroleum \& natural gas } \\
\text { Aircraft \& spacecraft; parts } \\
\text { Motor vehicles, trailers \& semi- } \\
\text { trailers; parts } \\
\text { Petroleum gases \& other gaseous } \\
\text { hydrocarbons, except natural gas } \\
\end{array}$ & $\begin{array}{l}\text { Textiles n.e.c. } \\
\text { Other plastics products } \\
\text { Basic organic chemicals } \\
\text { Other fabricated metal } \\
\text { products } \\
\text { Other rubber products }\end{array}$ \\
\hline
\end{tabular}

A closer look at these sectors shows that virtually all of the analyzed countries are introducing protective measures against imports of iron, steel and related products, chemicals, vegetables and fruits. India is actively introducing textile import safeguards, which is leading commodity export specialization of the country. Japan has been protecting the domestic market from imports of 
machinery and automotive products for a long period. The US and China are actively protecting the domestic market from imports of metal products (USChina Iron War has been going on for a long time and is gaining momentum). The only country that practically does not impede food imports is Canada. While in France and Italy, the food industry is one of the most protected.

Of course, the number of measures taken by states is not an absolute indicator of a country's activity in applying protectionist measures. First, the number of implementations may also depend on the number of existing and potential partners. Secondly, in our opinion, the size of the domestic market also plays a role (it is not entirely correct to compare the number of measures introduced by China and Italy, when the number of consumers differs by more than 20 times).

In this regard, it is appropriate to apply a relative indicator to characterize the ratio of protective and liberalizing measures applied by a country over a period of time (calculated by dividing the number of protective measures by the number of liberalizations). If the value is less than 1 , the state is more inclined to use measures of free trade policy, and more than 1 - the country is more actively using the tools of protectionism. However it should be mentioned, that the quantity of measures does not give the vision of the value of exports and imports influenced by it.

The calculation of the ratio for these countries in 2018 (using the data of the Global Trade Alert) showed the following results:

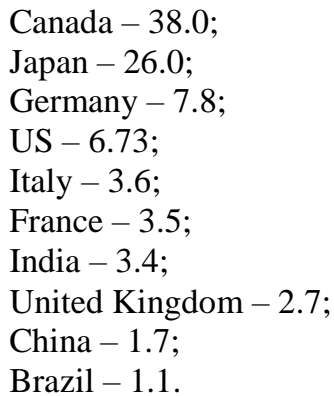

So, without the exception, the number of harmful interventions exceeded the number of liberalizing ones for all countries in the analyzed group of leading economies. The gap of the intensity of the indicator is more than 30 times (from 38.0 for Canada to 1.1 for Brazil). The ratio has the highest value for developed market economies, and is quite low for the new industrialized countries (China, India, Brazil).

Thus, in modern times the application of tariff and non-tariff measures of protectionism is a common characteristic of the foreign trade policy. The prevalence of such instruments in the foreign trade policies of states is 
increasing in the face of instability of the global economy, internal political changes and geopolitical contradictions.

\section{CONCLUSIONS}

The state's foreign trade policy is the primary level of implementation of the state's interests in the sphere of international trade. This policy as a system of instruments and mechanisms for influencing exports and imports, implements not only the task of achieving a positive balance of trade, balancing the structure of exports and imports. It is also aimed at reaching the leading positions in world markets, and often becomes a way of political influence. The application of rigid universal trade restrictions as a method of "punishing" countries that violate international law, and on the contrary, provision of mutual assistance in the form of customs clearance, cancellation of duties, or mutual recognition of product quality requirements is a decisive step in establishing relations between states.

The World Trade Organization played an important role in reducing the level of tariff protection of economies, which has helped to reduce the average level of tariff protection in the world from $35 \%$ in 1995 to $2.5 \%$ in 2017. At the same time, the application of so-called hidden protectionism, by which the domestic market is protected from foreign competition by other, non-tariff measures, has been intensified since 2018. According to the analysis of the dynamics and scope of such measures, most countries are using them to a more or less extent. Also, the introduction of measures to promote openness of markets for foreign suppliers is slowing down, especially in developed economies. New industrialized countries that are included in the top ten economies in the world (China, India, Brazil), are using restrictive measures sparingly and practically do not use them for food, which, by contrast, is quite common practice in the US and European countries.

\section{SUMMARY}

The paper is dedicated to the study of transition in the global trade policies from the view of increasing role of protective measures implemented by virtually all countries of the world. The factors, arguments and consequences of free-trade and protectionism are analyzed. Special attention is granted to neoprotectionism as a modern type of trade policy used by many countries of the world. The author studies the dynamics of the use of liberalizing and protective measures (tariff and non-tariff) in global economy since the global crisis of 2008. Based on the data provided by the Global Trade Alert database the conclusion is made about the countries with the most and the least "protective" trade policies, countries who are suffering from implemented protectionist measures and the most protected sectors of global trade. The EU technical 
regulation system is considered as effective and successful example of removing technical barriers to trade.

\section{REFERENCES}

1. Міжнародна економіка: підручник. Київ: Центр навчальної літератури, 2006. 224 с.

2. Келічавий А.В. Політика протекціонізму як фактор підвищення конкурентоспроможності економіки. Ефективна економіка. 2007. № 6. URL: http://www.economy.nayka.com.ua/?op=1\&z=3133 (дата звернення: 5.10.2019).

3. Козак Ю. Г. Міжнародна торгівля: навч.посібник. Київ: Центр учбової літератури, 2015. 272 с.

4. Баєва О.І. Теоретичні підходи до оцінки протекціонізму в міжнародній торгівельній практиці. Економіка $i$ суспільство. 2018. Вип. 16. С. 20-23. URL: http://economyandsociety.in.ua/journal/16_ukr/4.pdf (дата звернення: 6.10.2019).

5. History of the multilateral trading system. The World Trade Organization website. URL: https://www.wto.org/english/thewto_e/history_e/ history_e.htm_(Accessed 6 October 2019).

6. Патика Н.I. СОТ і розвиток економік країн-нових членів. Економіка і держава. 2012. № 4. С. 25-28. (дата звернення: 6.10.2019).

7. Regional trade agreements. URL: https://www.wto.org/english/ tratop_e/region_e/region_e.htm (Accessed 7 October 2019).

8. Матвєєнко В. К. Економічна глобалізація та регіональна інтеграція - дві форми інтернаціоналізації світового господарства. Вісник сочіально-економічних досліджень. 2013. Вип. 4. С. 282-287. URL: http://nbuv.gov.ua/UJRN/Vsed_2013_4_45 (дата звернення: 7.10.2019).

9. Бондарчук Л.В., Гусак К.Ю. Шляхи удосконалення зовнішньоторговельної політики України. Науковий вісник УжНУ. Серія «Міжнародні економічні відносини та світове господарство». 2018. Вип.19.Ч.1. С. 31-34 (дата звернення: 7.10.2019)

10. 2016-ий - Ренесанс протекціонізму. URL: http://www.dw.com/uk/ 2016-ий-ренесанс-протекціонізму/а-36924555_(дата звернення: 7.10.2019)

11. Tariff rate, applied, weighted mean, all products (\%). URL: https://data.worldbank.org/indicator/tm.tax.mrch.wm.ar.zs (Accessed 8 October 2019).

12. Developed Countries List 2019. URL: http://worldpopulationreview.com/ countries/developed-countries/ (Accessed 8 October 2019).

13. Total number of implemented interventions since November 2008. Global Trade Alert. URL: https://www.globaltradealert.org/global_dynamics/ day-to_1016/flow_all_(Accessed 8 October 2019). 
14. Protectionism, state discrimination, and international business since the onset of the Global Financial Crisis. ULR: https://www.globaltradealert.org/ reports/46_(Accessed 8 October 2019).

15. Countries. Global Trade alert. URL: https://www.globaltradealert.org/ countries (Accessed 8 October 2019).

\section{Information about the author: \\ Brenzovych K. S.,}

$\mathrm{PhD}$ in Economics,

Associate Professor at the International Economic Relations Department,

Uzhhorod National University

14, Universytetska str., Uzhhorod, 88000, Ukraine 


\title{
PARTY SYSTEM OF UKRAINE: CHARACTERISTICS OF THE MAIN PERIODS OF DEVELOPMENT (1991-2019)
}

\author{
Ostapets Yu. O.
}

\section{INTRODUCTION}

A modern democratic state is impossible without political parties, which are important elements of a democratic political system. In transitionsocieties the party system can even be called an indicator of democratization. The establishment of consolidated democracy also depends on the consolidation of the party system.

However, the formation of party systems is a complex process that depends on many factors and the specific historical conditions in which it takes place. Studying the experience of forming party systems in states where political democracy is just emerging is necessary for a theoretical understanding of the general patterns and socio-cultural features of the evolution of party systems. The understanding of such experience is necessary while studying the peculiarities of domestic party systemfunctioning.

The research is also updated by the fact that Ukrainian partogenesis requires its own research methodology, which would be formed taking into account the achievements of foreign political science, as well as the domestic experience of party formation. Therefore, there is an urgent need for new content, the reconceptualization of terms and categories that are used to analyze the party system of Ukraine. The problems of peroidization of the party system development also belong to disputable issues of modern science.

\section{Research methodology and empirical indicators of party system development in Ukraine}

Political science has a commonly accepted methodology to analyze the evolution of party systems in transitional societies, Ukraine included. Firstly, their functioning is preconditioned by a process of historical institutionalization. Political parties having emerged in new democratic societies usually function according to inclusive, cartel, and postmaterial values parties ${ }^{1}$. Secondly, the logic of their development is subordinated to the logic of democratic transition. In doing so, the researchers identify the following possible models of democratic transition: 1) successful transition; 2) the returning to the postauthoritarian regime; 3 ) interrupted transition (such states are referred to in a

1 Остапець Ю. Еволюція партійної системи України в умовах трансформації соціальних і політичних структур / Ужгород: ЗІППО, 2016. 252 с. 
different way, and namely: "pseudodemocracy", "delegative democracy", "bureaucratic patrimonialism", "hybrid state" etc.). Thirdly, the formation of the Ukrainian party system takes place within the context of interrupted transition. Successful transition to democracy is linked to the consolidation of party systems. A. Shherbak and H. Holosov argue that such a consolidation is associated with a decrease in party fragmentation (measured by the index of the effective number of parties) and electoral volatility (Pedersen's index $)^{2}$.

In our opinion, an index of nationalization of the party system, favoring the assessment of its regional development should be added to the empirical indicators of consolidation. The calculation of these indices for the Ukrainian party system is presented in Table 1.

Table 1

Empirical Indices of Party System Development in Ukraine (1998-2019)

\begin{tabular}{|c|c|c|c|c|c|c|c|}
\hline Indices & $\mathbf{1 9 9 8}$ & $\mathbf{2 0 0 2}$ & $\mathbf{2 0 0 6}$ & $\mathbf{2 0 0 7}$ & $\mathbf{2 0 1 2}$ & $\mathbf{2 0 1 4}$ & $\mathbf{2 0 1 9}$ \\
\hline ENPS & 4,9 & 4,7 & 3.4 & 3,3 & 4,3 & 4,8 & 2,7 \\
\hline ENPV & 9,0 & 6,9 & 5,2 & 3,8 & 4,9 & 7,5 & 4,4 \\
\hline IPed & - & 46 & 50 & 17 & 36 & 61 & 69 \\
\hline PSNS & 0,65 & 0,62 & 0,66 & 0,68 & 0,72 & 0,76 & 0,74 \\
\hline
\end{tabular}

The regional configuration of the party system of Ukraine is characterized within the framework of the theory of nationalization of political parties and party systems. According to $\mathrm{H}$. Holosov, the process of nationalization of party systems means the unification of electoral support of political parties in different territorial units of the state. The party system is fully nationalized when the proportions of votes received by the parties in different territorial units of the state are the same. If parties get electoral support only in some regions, the party system is considered to be nationalized ${ }^{3}$.

Since political science does not have a unified approach to the study of territorial homogeneity of electoral preferences, we will use the Index of Political Party Nationalization (PNS) and of Party Systems (PSNS), elaborated by $\mathrm{M}$. Jones and S. Meinvering. It has been successfully tested on electoral data $^{4}$. The results of calculating the nationalization index for the parliamentary parties of Ukraine are presented in Table 2.

2 Голосов Г. Фрагментация партийных систем: новый метод измерения и его применеие к результатам выборов российских региональных законодательных собраний (2003-2008). Электоральное пространство современной России. Политическая наука: Ежегодник 2008. М.: РОССПЭН, 2009. С. 9-27.

3 Голосов Г. Национализация партийной системы: российская специфика. Политическая наука. 2015. № 1. С. 128-156.

4 Туровский Р. Национализация и регионализация партийных систем: подходы к исследованию / Р. Туровский. Полития. 2016. № 1. С. 162-180. 
Table 2

Index of Nationalization of Parliamentary Parties According to the Results of elections to Verkhovna Rada (1998-2019)

\begin{tabular}{|c|c|c|c|c|c|c|}
\hline Parties / Election Blocs* & 1998 & 2002 & 2006 & 2012 & 2014 & 2019 \\
\hline 1 & 2 & 3 & 4 & 5 & 6 & 7 \\
\hline Narodnyj Rukh Ukrajiny & 0,561 & & & & & \\
\hline Partija Zelenykh Ukrajiny & 0,855 & & & & & \\
\hline $\begin{array}{l}\text { "Social Party of Ukraine } \\
\text { and the Peasant Party of } \\
\text { Ukraine" election bloc }\end{array}$ & 0,525 & & & & & \\
\hline $\begin{array}{l}\text { Communist Party of } \\
\text { Ukraine }\end{array}$ & 0,705 & 0,644 & 0,725 & 0,668 & & \\
\hline $\begin{array}{l}\text { All-Ukrainian unity } \\
\text { "Ghromada" }\end{array}$ & 0,515 & & & & & \\
\hline $\begin{array}{l}\text { Progressive Socialist Party } \\
\text { of Ukraine }\end{array}$ & 0,554 & & & & & \\
\hline $\begin{array}{l}\text { Social Democratic Party of } \\
\text { Ukraine (united) }\end{array}$ & 0,597 & 0,666 & & & & \\
\hline National Democratic Party & 0,811 & & & & & \\
\hline $\begin{array}{l}\text { "National Front" } \\
\text { Election Bloc }\end{array}$ & 0,281 & & & & & \\
\hline $\begin{array}{l}\text { Viktor Jushhenko's “Our } \\
\text { Ukraine”Election Block }\end{array}$ & & 0,553 & 0,603 & & & \\
\hline $\begin{array}{l}\text { "Za Jedynu Ukrajinu" } \\
\text { Election Bloc }\end{array}$ & & 0,681 & & & & \\
\hline $\begin{array}{l}\text { Julija Tymoshenko ‘s } \\
\text { Election Blok / } \\
\text { All-Ukrainian Unity } \\
\text { "Batjkivshhyna" *** }\end{array}$ & & 0,639 & 0,705 & 0,761 & 0,846 & 0,77 \\
\hline Socialist Party of Ukraine & & 0,514 & 0,633 & & & \\
\hline Party of Regions & & & 0,541 & 0,685 & & \\
\hline Political Party "Udar" & & & & 0,828 & & \\
\hline $\begin{array}{l}\text { All-Ukrainian Unity } \\
\text { "Svoboda" }\end{array}$ & & & & 0,534 & & 0,55 \\
\hline $\begin{array}{l}\text { Political Party } \\
\text { "People "s Front" }\end{array}$ & & & & & 0,754 & \\
\hline $\begin{array}{l}\text { Political Party "Petro } \\
\text { Poroshenko's bloc" / } \\
\text { Political Party "European } \\
\text { Solidarity" **** }\end{array}$ & & & & & 0,891 & 0,73 \\
\hline
\end{tabular}


Table 2 (continued)

\begin{tabular}{|c|c|c|c|c|c|c|}
\hline 1 & 2 & 3 & 4 & 5 & 6 & 7 \\
\hline $\begin{array}{l}\text { Political Party } \\
\text { "Samopomich Union" }\end{array}$ & & & & & 0,804 & 0,57 \\
\hline $\begin{array}{l}\text { Political Party } \\
\text { "Opposition bloc" }\end{array}$ & & & & & 0,418 & 0,56 \\
\hline $\begin{array}{l}\text { Oleh Ljashko’s } \\
\text { Radical Party }\end{array}$ & & & & & 0,805 & 0,71 \\
\hline $\begin{array}{l}\text { Political Party } \\
\text { "People's Servant" }\end{array}$ & & & & & & 0,89 \\
\hline $\begin{array}{l}\text { Political Party } \\
\text { "Opposition Platform - } \\
\text { For Life" }\end{array}$ & & & & & & 0,55 \\
\hline $\begin{array}{l}\Pi \text { «Голос» } \\
\text { Political Party "Voice" }\end{array}$ & & & & & & 0,58 \\
\hline $\begin{array}{l}\text { Nationalization } \\
\text { of the Party System } \\
\text { of Ukraine }\end{array}$ & 0,64 & 0,62 & 0,66 & 0,72 & 0,76 & 0,74 \\
\hline
\end{tabular}

*Beginning with 2012 parliamentary elections, election blocs don't participate in the elections.

**In 2006 "Our Ukraine" election block.

*** In 2012, 2014, 2019 - "Batjkivshhyna" election bloc.

**** In 2019 p. - political party "European Solidarity".

To characterize the peculiarities of the development of the party system of Ukraine, we suggest to consider the stages of its evolution within the context of our study. The key points of the periodization is the accentuation of the periods based on the so-called major electoral cycles, including parliamentary, presidential and local elections. As the starting point of such an electoral cycle, the next parliamentary elections should be considered. But taking into consideration the status of the President of Ukraine in the system of state power, the scope of his power and the mechanisms of influence on the internal politics of the state, presidential elections might be considered as the starting point of the electoral cycle. According to the results of 2004, 2010, 2014 presidential elections, the form of the government was changed, and new party structures, dominating Ukrainian politics for a period of time, were formed.

The changes in the content structure and the form of the government might be attributed to the criteria of period accentuation. So, period division looks like this: the first period lasts from 1991 to 2004, the second - from 2004 to 2014, the third from 2014 to 2019 , and the fourth starts in 2019. It should be noted that in 2010 there was a change in the form of the government, however 
we do not single out a new period in the development of the party system, since there were no significant changes in its structure.

The main factors influencing the evolution of the party system are the following: electoral processes; features of democratic transit (hybrid political regime); socio-political distinctions; the institutional environment (presidentialism, the lack of proper regulatory framework, constant changes in the electoral system, etc.); constitutional volatility (changing the form of government in 2004, 2010, 2014); traditions of clientelism, paternalism, regionalism; regionalization of party influence and the emergence of regional parties.

\section{Development of the party system of Ukraine during 1991-2019}

The first period (1991-2004) in the development of the party system was characterized by the opposition of independence supporters and proWestern foreign policy orientation with the supporters of the idea of preserving the former USSR and reintegration within its borders.

Presidential, parliamentary and local elections had a decisive influence on both the national and regional configuration of the party system. Attention should be paid to "constituent elections", to which we attribute 1990, 1994 elections to Verkhovna Rada of Ukraine and 1991 and 1994 presidential elections.

The analysis of their results shows that their impact on political processes in Ukraine was ambivalent. On the one hand, the constituent elections successfully fulfilled their functions within the period of a democratic transition: they established an institutional design within which both electoral competition and party system evolve; created the models of electoral behavior of the population, having a pronounced regional character; created the basis for legitimizing the future political regime ${ }^{5}$. On the other hand, they contributed to the establishment of a hybrid political regime in Ukraine.

The results of the parliamentary elections during 1998-2019 (party winners listed on the party lists) are presented in Table 3 . The table does not indicate the results of the 2007 snap elections since they did not have a significant impact on the configuration of the party system.

A characteristic feature of 1998 parliamentary elections was the emergence of the phenomenon of political parties of one region. Voting for such parties was fixed in Transcarpathian (Social Democratic Party of Ukraine (United) - 31, 17\%), Dnipropetrovsk (all-Ukrainian Union "Ghromada"$35,34 \%$ ) and Sumy ("Progressive Socialist Party of Ukraine" - 20,89\%)

5 Манайло-Приходько Р. Вплив «установчих» виборів на еволюцію партійної системиУкраїни. Гілея: науковий вісник. Збірник наукових праџь. К.: «Видавництво «Гілея», 2018. Випуск 135. С. 362-367. 
regions. Due to such voting, these parties overcame the $4 \%$ barrier of voters in Ukraine 6 .

Table 3

Results of the Elections to Verkhovna Rada of Ukraine in 1998- 2019

\begin{tabular}{|c|c|c|c|c|c|c|}
\hline Parties / Election Blocs* & $\begin{array}{c}1998, \\
\%\end{array}$ & $\begin{array}{c}2002, \\
\%\end{array}$ & $\begin{array}{l}2006, \\
\%\end{array}$ & $\begin{array}{c}2012, \\
\%\end{array}$ & $\begin{array}{c}2014, \\
\%\end{array}$ & $\begin{array}{c}2019, \\
\%\end{array}$ \\
\hline 1 & 2 & 3 & 4 & 5 & 6 & 7 \\
\hline Narodnyj Rukh Ukrajiny & 9,4 & & & & & \\
\hline Partija Zelenykh Ukrajiny & 5,43 & & & & & \\
\hline $\begin{array}{l}\text { "Social Party of Ukraine } \\
\text { and the Peasant Party of } \\
\text { Ukraine" election bloc }\end{array}$ & 8,55 & & & & & \\
\hline $\begin{array}{l}\text { Communist Party of } \\
\text { Ukraine }\end{array}$ & 24,65 & 19,98 & 3,66 & 13,18 & & \\
\hline $\begin{array}{l}\text { All-Ukrainian unity } \\
\text { "Ghromada" }\end{array}$ & 4,67 & & & & & \\
\hline $\begin{array}{l}\text { Progressive Socialist Party } \\
\text { of Ukraine }\end{array}$ & 4,04 & & & & & \\
\hline $\begin{array}{l}\text { Social Democratic Party of } \\
\text { Ukraine (united) }\end{array}$ & 4,01 & 6,27 & & & & \\
\hline National Democratic Party & 5,01 & & & & & \\
\hline $\begin{array}{l}\text { Viktor Jushhenko's “Our } \\
\text { Ukraine”Election Block }\end{array}$ & & 23,57 & 13,95 & & & \\
\hline $\begin{array}{l}\text { "Za Jedynu Ukrajinu" } \\
\text { Election Bloc }\end{array}$ & & 11,77 & & & & \\
\hline $\begin{array}{l}\text { Julija Tymoshenko ‘s } \\
\text { Election Bloc / } \\
\text { All-Ukrainian Unity } \\
\text { "Batjkivshhyna" *** }\end{array}$ & & 7,26 & 22,29 & 25,24 & 5,68 & 8,18 \\
\hline Socialist Party of Ukraine & & 6,87 & 5,69 & & & \\
\hline Party of Regions & & & 32,14 & 30,0 & & \\
\hline Political Party "Udar" & & & & 13,96 & & \\
\hline $\begin{array}{l}\text { All-Ukrainian Unity } \\
\text { "Svoboda" }\end{array}$ & & & & 10,44 & & \\
\hline
\end{tabular}

6 Остапець Ю. Електоральні процеси в Україні: загальнонаціональний та регіональний виміри. Дисертація на здобуття наукового ступеня доктора політичних наук (23.00.02 - політичні інститути і процеси). Львів, 2016. 550 c. URL: http://www.lnu.edu.ua/wpcontent/uploads/2016/11/dis_ostapets.pdf 
Table 3 (continued)

\begin{tabular}{|c|c|c|c|c|c|c|}
\hline 1 & 2 & 3 & 4 & 5 & 6 & 7 \\
\hline $\begin{array}{l}\text { Political Party } \\
\text { "People "s Front" }\end{array}$ & & & & & 22,14 & \\
\hline $\begin{array}{l}\text { Political Party "Petro } \\
\text { Poroshenko's bloc" / } \\
\text { Political Party "European } \\
\text { Solidarity" **** }\end{array}$ & & & & & 21,82 & 8,10 \\
\hline $\begin{array}{l}\text { Political Party } \\
\text { "Samopomich Union" }\end{array}$ & & & & & 10,97 & \\
\hline $\begin{array}{l}\text { Political Party } \\
\text { "Opposition bloc" }\end{array}$ & & & & & 9,43 & \\
\hline $\begin{array}{l}\text { Oleh Ljashko's } \\
\text { Radical Party }\end{array}$ & & & & & 7,44 & \\
\hline $\begin{array}{l}\text { Political Party } \\
\text { "People's Servant" }\end{array}$ & & & & & & 43,16 \\
\hline $\begin{array}{l}\text { Political Party "Opposition } \\
\text { Platform - For Life" }\end{array}$ & & & & & & 13,05 \\
\hline $\begin{array}{l}\Pi \text { «Голос» } \\
\text { Political Party "Voice" }\end{array}$ & & & & & & 5,82 \\
\hline
\end{tabular}

*Beginning with 2012 parliamentary elections, election blocs don't participate in the elections.

**In 2006 "Our Ukraine" election block.

*** In 2012, 2014, 2019 - "Batjkivshhyna" election bloc.

**** In 2019 p. - political party "European Solidarity".

The 2002 parliamentary elections became a point of bifurcation in the development of the party system. If, before 2002, its socio-economic and ideological demarcation had a dominant influence on its evolution, then after the elections it became a socio-cultural one. Accordingly, in the Western and Central regions the victory was gained by the Opposition Victor Yushchenko's bloc "Our Ukraine", which was based on political parties of nationaldemocratic orientation, and in the South and East, by the pro-government bloc "For a United Ukraine!" being formed by the centrist parties ${ }^{7}$.

Updating the socio-cultural division has "simplified" the task of the political forces in the next election campaigns. It was used in their election messages by both national democrats and their opponents (communist, centrist parties). The purpose of consolidation of the electorate was achieved through

${ }^{7}$ Трансформація партійної системи: український досвід у європейському контексті / За ред. Ю. Якименка. Київ: Центр Разумкова, 2017. С. 76. 
the appeal to issues on which the residents of different regions had different views (language, cultural values, foreign policy priorities). So, if before 2004 presidential election the socio-cultural division was reflected in the election results (parliamentary and presidential, being one of the factors influencing the structure of the party system, then during the 2004 election campaign it became a major factor influencing its configuration ${ }^{8}$. In addition, the specificity of the parliamentary elections was the structuring of the main subjects of the electoral process in the form of party blocs, which led to the loss of their recognition, their "dissolution" in the election blocs, and eventually to oblivion.

The second period (2004-2014) was characterized by socio-cultural confrontation along the East-West axis. Its peculiarity is manifested in the stability of the electoral map, which emerged as a result of 2004 presidential election and then was reflected in 2006, 2007, 2012 and 2010 parliamentary elections. The 2004 presidential election had a decisive influence on the configuration of Ukraine's party space. Firstly, the election resulted in the emergence of two electoral parts of Ukraine - Eastern and Western, being completely opposite: V. Yushchenko won in 17 regions (West, Center), and V. Yanukovych - in 10 regions (East, South). Secondly, the implementation of political reform (the law of December 8, 2004) meant holding parliamentary and local elections in a proportional system, and consequently an institutional strengthening of the status of political parties ${ }^{9}$. Accordingly, in 2006 elections to the Verkhovna Rada of Ukraine, the first place was won by Julija Tymoshenko "s election bloc and "Our Ukraine", in the regions where Viktor Yushchenko won, and in the regions where Viktor Yanukovych won, the first place was won by the "Party of Regions".

It should be noted that the results of 2006 and 2010 local elections point to the emergence of powerful regional parties in Ukraine. The main reasons for the emergence of regional political parties in Ukraine are: socio-cultural EastWest demarcation; ethno-linguistic difference and compact residence of national minorities in a certain territory (e.g. Hungarian minority in Transcarpathian region); timing of local and parliamentary elections (since 2010 local elections have been held separately from parliamentary ones); the regulatory and legal basis of the activities of political parties; reform of power decentralization and the formation of united territorial communities; the desire of regional elites to maintain influence and control over local resources; personal factor; administrative resource.

\footnotetext{
${ }^{8}$ Трансформація партійної системи: український досвід у європейському контексті / За ред. Ю. Якименка. Київ: Центр Разумкова, 2017. 428 с.

9 Остапець Ю. Еволюція партійної системи України в умовах трансформації соціальних і політичних структур/ Ужгород: ЗІППО, 2016. С. 136.
} 
The 2010 presidential election, which began a new electoral cycle, became a kind of continuation of the 2004 election, as it was held in opposition between political candidates from the East and the West of Ukraine. As in 2004, most of the western and central regions voted in favor of Yulia Tymoshenko ("Batjkivshhyna"), while the eastern and southern regions voted in favor of V. Yanukovych ("Party of Regions").

After the elections, deputies from the "Party of Regions" initiated the amendments to the Constitution of Ukraine, and on October 1, 2010 the Constitutional Court of Ukraine declared that the Law on Amendments to the Constitution of Ukraine of December 8, 2004, did not correspond to the Constitution of Ukraine due to the violation of the procedure of its consideration and adoption. The result was a return to the Constitution of 1996, and hence to a presidential-parliamentary form of government ${ }^{10}$.

So, if, following the results of 2010 local elections, the party system of Ukraine receives the format of a system with a dominant party of dominance, then by the results of 2012 parliamentary elections, it becomes two-pronged; the "Party of Regions", and the Communist party on the one hand, and allUkrainian unities "Batjkivshyna", "Svoboda" and the political party "Udar" on the other hand.

The third period (2014-2019) in the development of Ukraine's party system begins with a change in the electoral space structure (the victory of proEuropean-oriented political parties in most regions of Ukraine), the emergence of new political parties connected with the early presidential and 2014 parliamentary elections, changing the form of government (returning to the parliamentary-presidential one).

The early 2014 elections to the Verkhovna Rada of Ukraine changed dramatically the format of the party system and its structure. As a result of the elections, 4 new political parties were initiated into the Ukrainian Parliament: political party "People's Front", political party "Petro Poroshenko's Bloc", political party "Opposition Bloc", political party "Samopomich Union", Oleg Lyashko's Radical Party. From the previous composition of the Verkhovna Rada, only "Batkivshchyna" passed the barrier with the lowest result". The changes that have taken place in the composition structure of the party system make it possible to call it "the second Ukrainian party system". The first one was formed within 1991-2012.

The 2015 local council elections completed the "revolutionary electoral cycle" and finally confirmed the configuration of the party system.

10 Остапець Ю. Еволюція партійної системи України в умовах трансформації соціальних і політичних структур/ Ужгород: ЗІППО, 2016. С. 167.

${ }^{11}$ Партійна система України до і після Майдану: зміни, тенденції розвитку, суспільні запити. Національна безпека і оборона України. 2015. № 6-7. 18. С. 134. 
A characteristic feature of elections is the participation of a large number of regional and sub-regional parties. For example, political party "Sergiy Kaplin's Party of Ordinary People" in Poltava, political party "All-Ukrainian union "Cherkashhyna" in Cherkasy region, political party "Trust the affairs" in Odessa, political party "United Center", "KMKS - Party of the Hungarians of Ukraine, the "Democratic Party of Hungarians of Ukraine) and others ${ }^{12}$.

It should be noted that a number of political parties that have been represented in local authorities have chosen another electoral tactics, concentrating the forces at regional or sub-regional levels, nominating their candidates to a small number of local councils. The regional localization of such parties is related to: a) working efficiency of individual local units of the national party (the principle of functioning of a multi-level party); b) providing the participants interested in the election process with the party brand (political franchise); c) functioning of national parties in separate regions according to the principle of "regional party-electoral machines".

\section{Changing the Configuration of Ukraine's Party System Following the 2019 Presidential and Parliamentary elections}

The fourth period (begins in 2019) began with the 2019 presidential and parliamentary elections. It should also be noted that the parliamentary elections took place immediately after the presidential elections (political experts called them the "third" presidential round), and therefore the presidential campaign had a decisive influence on the result of the elections to the Verkhovna Rada of Ukraine. But if the presidential election were directed against the previous political and ruling elite, headed by P. Poroshenko, the parliamentary elections demonstrated the consolidation of Ukrainian citizens around new political ideas and trends, including the European choice of Ukraine.

The logic of the election campaign was constructed by the candidates as follows: some candidates with pro-European slogans counted on the support of the West and the Center of Ukraine, and the other part - on the East and the South. The logic was justified and provided good electoral dividends for both the pro-government and opposition political forces during 1991-2014, though the society received a regional split.

But 2019 presidential election was different from the previous one due to the fact that the electorate was oriented on a dramatic change in the Ukrainian political party. Such a demand of the electorate, being fixed in a sociological survey, coincides with the appearance of atypical, not connected with old political candidates - V. Zelensky. V. Zelensky carried out its election campaign without

12 Остапець Ю. Еволюція партійної системи України в умовах трансформації соціальних і політичних структур/ Ужгород: ЗІППО, 2016. С. 226. 
using socio-cultural messages, which divide an electorate into the East and the West (language, religion, geopolitical practice), but focus on the problems common to all the Ukrainians - stopping the war, fighting the corruption, welfare improvement. The calculation of V. Zelensky's election headquarters proved to be correct. Out-of-system character of the candidate, the emphasis on vitally important issues influenced the electoral results, and he won the first round of the elections ${ }^{13}$. Table 4 shows the results of the first round of elections for candidates who gained more than $1 \%$ of the vote. The table also shows the results of national exit polls, party affiliation / party support for candidates, the uniformity index of voting for political parties that supported candidates for the presidency in the 2014 parliamentary elections (PNS), and the uniformity index of support for candidates in the first round of presidential elections (PNS for candidates). The results of the presidential election show that the Homogeneity Index (in our case Jones - Mainwaring Nationalization Index is calculated) of regional voting for the main presidential candidates, each of them being represented by a political party, is low. Accordingly, the 2019 presidential election shows that voting for candidates was regional in nature. The only exception was V. Zelensky's candidacy, whose vote homogeneity index was the highest -0.84 .

Table 4

Results of the First Round of the Presidential Elections (2019) in Terms of Homogeneity/Heterogeneity of the Regional Voter Choice

\begin{tabular}{|c|c|c|c|c|c|}
\hline $\begin{array}{l}\text { Names of the } \\
\text { Cndidates }\end{array}$ & $\begin{array}{c}\text { Political } \\
\text { party }\end{array}$ & 完 & 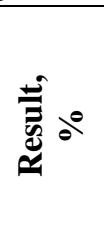 & 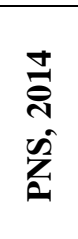 & 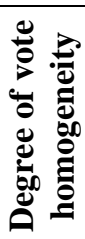 \\
\hline 1 & 2 & 3 & 4 & 5 & 6 \\
\hline Zelensky V. & $\begin{array}{l}\text { political party } \\
\text { "Sluha Narodu" } \\
\text { ("People's Servant") }\end{array}$ & 30,6 & 30,24 & - & 0,84 \\
\hline Poroshenko P. & $\begin{array}{l}\text { Political party "Bloc Petra } \\
\text { Poroshenka "Solidarnist"" } \\
\text { ("Petro Poroshenko's } \\
\text { Bloc" "Solidarity" }\end{array}$ & 17,8 & 15,95 & 0,89 & 0,77 \\
\hline Tymoshenko Yu. & $\begin{array}{l}\text { all-Ukrainian union } \\
\text { "Batjkivshchyna" } \\
\text { ("Fatherland") }\end{array}$ & 14,2 & 13,4 & 0,85 & 0,81 \\
\hline
\end{tabular}

${ }^{13}$ Рябчук М. Випробування виборами.URL.: https://zbruc.eu/node/91268 
Table 4 (continued)

\begin{tabular}{|c|c|c|c|c|c|}
\hline 1 & 2 & 3 & 4 & 5 & 6 \\
\hline Boiko Yu. & $\begin{array}{l}\text { political party } \\
\text { "Opozytsiyny bloc" } \\
\text { ("Opposition Bloc") }\end{array}$ & 9,7 & 11,67 & 0,42 & 0,55 \\
\hline Hrytsenko A. & $\begin{array}{l}\text { political party } \\
\text { "Hromadjska posytsia" } \\
\text { ("Civic Position") }\end{array}$ & 7,1 & 6,91 & 0,85 & 0,66 \\
\hline Smeshko I. & $\begin{array}{l}\text { political party } \\
\text { "Syla I Chest"" } \\
\text { ("Strength and Honor" }\end{array}$ & 6,5 & 6,04 & 0,83 & 0,79 \\
\hline Lyashko O. & $\begin{array}{l}\text { Radykalna Partia Oleha } \\
\text { Lyashka ("Oleh Lyashko's } \\
\text { Radical Party") }\end{array}$ & 4,7 & 5,48 & 0,81 & 0,74 \\
\hline Vilkul O. & $\begin{array}{l}\text { political party } \\
\text { "Opposition Bloc, } \\
\text { the Party of Peace } \\
\text { and development" }\end{array}$ & 4,0 & 4,15 & - & 0,51 \\
\hline Koshulynsky R. & $\begin{array}{l}\text { All-Ukrainian union } \\
\text { "Svoboda" }\end{array}$ & 1,7 & 1,62 & 0,75 & 0,51 \\
\hline
\end{tabular}

According to the first round results, V. Zelensky won the elections in most regions of Ukraine, except those where Yuriy Boyko (Donetsk, Luhansk oblasts), Y. Tymoshenko (Ivano-Frankivsk region), P. Poroshenko (Lviv, Ternopil regions) received the majority of votes) ${ }^{14}$. In the second round V. Zelensky won with a result of $73,22 \%$, whereas his opponent P. Poroshenko - received $24,45 \%$. V. Zelensky won the elections in all the regions of Ukraine except for Lviv.

Consequently, the following conclusions can be drawn from the election results. Firstly, "greening" (V. Zelensky's victory) does not imply reunification of Ukraine. The electorate of Ukraine remained divided at the level of identities (Eastern / Western). Its unification is possible at the expense of a prudent national policy that will take into account the requests of both the population of the East and the West of Ukraine. Secondly, the presidential election had a decisive influence on the parliamentary election campaign, outlining its format and vectors of political competition. Most presidential candidates were members of political parties, or nominated by political parties. Therefore, their participation in the elections is an opportunity to test the party brands ranking in the presidential campaign. The ratings of party brands in the presidential

\footnotetext{
${ }^{14}$ Офіційний сайт Центральної виборчої комісії. URL: http://www.cvk.gov.ua
} 
campaign are presented in Table 4. Thirdly, the election results showed that voters in the parliamentary elections would first and foremost give priority to new, non-governmental political forces.

The 2019 parliamentary elections were extraordinary since the Verkhovna Rada of Ukraine was dissolved by the Decree of the President of Ukraine V. Zelensky immediately after his inauguration on May 21, 2019, as such, where no parliamentary majority was formed. The elections were held in accordance with the law (with minor changes), adopted in November 2011, which established a mixed electoral system with election threshold of 5\% and a ban on political party blocs ${ }^{15}$.

The participants of the presidential race can be divided into the following groups: 1) the pro-presidential party "People's Servant"; 2) parliamentary political parties: "Batjkivshhyna", "Samopomich", political party "European Solidarity" (formed as a result of the re-branding of Petro Poroshenko's Bloc "Solidarity", political party "Opposition Bloc"; 3) wellknown party brands, who have repeatedly participated in election campaigns: all-Ukrainian unity "Svoboda", political party "Civic Position", Agrarian Party of Ukraine, political party "Power and Honor", "Patriot", and others; 4) new political parties that first participated in the parliamentary elections: the "Voice", the "Ukrainian Groisman's Strategy", the "Sharia's Party", "People's Power" and others ${ }^{16}$. The results of the 2019 parliamentary elections have significantly changed the configuration of Ukraine's party system at both the national and regional levels. According to the election outcome, 4 out of 5 new political parties overcame the 5 percent election threshold and entered the Parliament: "People's Servant", "Opposition Platform - For Life", "European Solidarity" and "Voice". From the original composition of the Verkhovna Rada, only "Batjkivshhyna" managed to enter the new Parliament. Therefore, the changes in the format of the system were so drastic that it could be called the "third" party system in Ukraine (the "second" was formed after the 2014 parliamentary elections, when 4 new political forces entered the Parliament).

During the parliamentary elections, the political party "People's Servant" associated with V. Zelensky, did not speculate on identity issues (European choice, recovery of historical memory, national church, etc.), which led to a uniform result throughout Ukraine (nationalization index is equivalent to 0.89 ). Political party "People's Servant" skillfully took into account the ambivalence of the Ukrainian electorate (Western / Eastern) in their pre-election rhetoric, emphasizing the importance of combating corruption, changing the old political elite, cease of the war, etc.

15 Закон України «Про вибори народних депутатів України» (17 листопада 2011 р.). URL: https://zakon.rada.gov.ua/laws/show/4061-17

${ }^{16}$ Рябчук М. Випробування виборами. URL: https://zbruc.eu/node/91268 
Thus, due to the results of the parliamentary elections the following conclusions can be made. Firstly, radical changes have taken place in the structure and configuration of the party system. The party system is represented by a system with the dominant party. The effective number of parliamentary parties decreased to 2.7 and the electoral ones to 4.4. Instead, the volatility index had the highest index during 1998-2019, which is explained by the "electoral revolution" of 2019. All the other winning parties can be called regional, which is confirmed by the calculations of the Nationalization index and the zoning of electoral support: political party the "European Solidarity", political party the "Voice" -0.58 , political party the "Batjkivshhyna" -0.77 , political party the "Opposition Platform - For Life" - 0.55.

All of them continued losing electoral support as they proceeded from the west to the east (political party "Solidarity", political party "Voice", "Batjkivshhyna", or vice versa - from east to west ("Opposition Platform - For Life", "Opposition Bloc", political party "Sharia's Party"). According to the results of the 2019 parliamentary elections the overall index of the nationalization of the party system of Ukraine is equivalent to 0.74 . This is one of the highest figures in the history of parliamentary elections in Ukraine.

The political party "People's Servant" has demonstrated an absolute record in the history of parliamentary elections, obtaining $43.16 \%$ of the votes (124 mandates) introducing 130 deputies into the majority districts. The party obtained the majority (254 MPs) in the Parliament and formed a new government, taking full responsibility for domestic and foreign policies of the state. Secondly, the political parties that succeeded in the elections were formed due to rebranding or splitting in old party structures, and therefore all of them were virtual organizations that had no organizational structures in the regions of Ukraine before the elections. Despite that, they were able to gain considerable voter support ${ }^{17}$.

The political party "People's servant" was formed due to rebranding of the "Party of Decisive Change", which was registered on April 13, 2016. The party's political ideology is libertarianism. Named after the eponymous Ukrainian comedy political series, in which a simple history teacher played by V. Zelensky became the president. Television series and feature films is considered to be one of the political technologies that has been successfully applied to win the elections. Political party "Voice" was established at the initiative of the frontman of the famous Ukrainian rock band "Ocean Eljzy" S. Vakarchuk through renaming the political party "Platform of Initiatives" on May 21, 2019. The political party is characterized by centre-right, pro-European ideology. Similarly to the political party "People's Servant", the political party

\footnotetext{
${ }^{17}$ Офіційний сайт Центральної виборчої комісії. URL: http://www.cvk.gov.ua
} 
"Voice" had no fixed party structure at the beginning of the election campaign. Political party "European Solidarity" is the political party "Petro Poroshenko's Bloc "Solidarity", renamed on May 24, 2019. The reason for the change of the name was the electoral defeat of P. Poroshenko in the presidential race and the need to change their political strategy and tactics ${ }^{18}$.

The political party "Political Platform - For Life" was formed as a result of the split in political party "Opposition Bloc", which represented the former "Party of Regions" and always consisted of two groups: "Donetsk industrialists" (R. Akhmetov, V. Novinsky) and "gas business representatives" (D. Firtash, S. Lyovochkin, Y. Bojko). The representatives of these groups could not agree to a merger, and therefore participated in the elections in the format of individual parties - political party "Opposition Bloc" and political party "Opposition Platform - For Life." In order to strengthen the positions, R. Akhmetov's group has teamed up with several regional parties: the political party "Trust in Affairs" (G. Trukhanov, G. Kernes), the political party "Renaissance" (V. Khomutinnik, E. Geller) and the "Ours" (E. Murajev) ${ }^{19}$.

In accordance with the plan of the leaders, such an association should have provided synergy and demonstrate the electorate a unified party of "successful businessmen and industrialists" in the South East. However, such an expansion of the political party "Opposition Bloc" did not add electoral potential and was not able to overcome the electoral threshold.

The political party "Ukrainian Groysman's Strategy" and political party "Sharia's party" also became the subjects to the electoral process. These parties have received significant voters support, allowing them to receive state funding. The first one was established by the Prime Minister of Ukraine V. Groysman, who decided to take part in the parliamentary elections with his own political force, and the second one is the political party of the famous pro-Russian blogger A. Sharia.

Thus, except for the all-Ukrainian unions "Batjkivshhyna" and "Svoboda", "Oleg Lyashko's Radical Party", "Opposition Bloc", the majority of the subjects of the electoral process virtually had no organizational structures in the regions; there were virtual structures that carried out agitation by means of political advertising in the media and social networks. Therefore, the election showed the increasing role of social networks in the election campaign and the tendency to "virtualize" Ukrainian parties ${ }^{20}$.

18 Фесенко В. Дневник парламентских выборов - 2019: финал. URL.: https://blogs.pravda.com.ua/authors/fesenko/

${ }^{19}$ Сухарина А. Хто, де і як голосував на виборах до Ради. URL.: https://dif.org.ua/ article/bitva-pokolin-khto-de-i-yak-golosuvav-na-viborakh-do-radi

20 Леліч М. Повз Раду: чим займуться партії та їхні лідери, що не потрапили в новий парламент. URL: https://www.rbc.ua/ukr/news/mimo-rady-zaymutsya-partii-lidery-popavshie1564863190.html 
Thirdly, political force that speculated on the threat of Russophobia, nationalism, fascism - an all-Ukrainian union "Svoboda" - received a poor rating. Despite the fact that it united 4 other nationalist parties on its platform (political parties "National Corpus", the "Congress of Ukrainian Nationalists", the "Organization of Ukrainian Nationalists", and the political party "Right Sector), its result made up only $2.15 \%$ of the vote.

Fourthly, elections in majority districts destroyed the old patron-client model of voting, when a major-deputy engaged in the improvement of the district, would provide material aid (both financial assistance and food aid), and voters would "thank" him with their votes. In our opinion, it will be practically impossible to return to this election model in the future, being one of the arguments for establishing a proportional electoral system.

\section{CONCLUSIONS}

In our opinion, the 2019 presidential and parliamentary elections can be called a "Ukrainian electoral revolution" for at least of two reasons. Firstly, as a result of the elections, there was a change of generations in the Ukrainian political elite, since young politicians aged 25-35 mostly came to power in order to change drastically the state of affairs in Ukrainian politics. Secondly, the Ukrainian citizens wanted radical changes, being the main motivating determinant for voting. The basic message of both election campaigns was the message to change the old political elite, hence, the political parties putting that idea forward and being represented in the party lists under new names received the majority of votes (political party "People's Servant" and political party "Voice").

Both the national and regional configuration of the party system of Ukraine are constituted by the following components: 1) national parliamentary political parties that have overcome the electoral threshold; 2) national nonparliamentary parties that obtained at least $2 \%$ of the votes in the elections to the Verkhovna Rada of Ukraine; 3) regional political parties represented in regional and district councils of several regions; 4) sub-regional parties: a) political parties of one / several single-mandate constituencies; local parties that situationally use local policies to provide electoral support for local government elections. High level of volatility, in comparison with relatively low value of the index of the nationalization of political parties, according to the 2019 parliamentary elections results, indicates that despite the significant changes in the structure of the party format, the heterogeneity (regionality) of party preferences in Ukrainian citizens remains high (Table 2). And the increase in the level of electoral homogeneity in the parliamentary elections of 2014 and 2019 does not yet determine the tendency to increase the level of nationalization of the party system, since the attitude towards the identity characteristics of the 
society before and during the 2019 election campaigns remained polarized along the East-West line. Thus, two tendencies in the development of Ukraine's party system can be traced: nationalization and regionalization. At different stages of the development, one of them, depending on the cumulative effect of a number of factors, becomes clearly evident.

\section{SUMMARY}

The party system is one the society subsystems being substantially affected by a number of factors, and namely: socio-political demarcation, the electoral system, the party's legal core functional group, electoral actions. As a rule, its configuration, regional activity, and structure are being changed. Hence, the consideration of traditional tendencies of party systemsdevelopment still remains one of the topical problems of domestic political science.

The paperdescribes the development of Ukrainian party system within 1991-2004, 2004-2014, 2014-2019 periods, starting with 2019. It has been concluded that two trends are clearly observed in the development of Ukraine's party system: nationalization and regionalization. Within different periods of development, one of them, being influenced by a number of factors, is more clearly manifested.

\section{REFERENCES}

1. Голосов Г. Фрагментация партийных систем: новый метод измерения и его применеие к результатам выборов российских региональных законодательных собраний (2003-2008). Электоральное пространство современной России. Политическая наука: Ежегодник 2008. М.: РОССПЭН, 2009. С. 9-27.

2. Голосов Г. Национализация партийной системы: российская специфика / Г. Голосов, В. Григорьев. Политическая наука. 2015. № 1. C. $128-156$.

3. Закон України «Про вибори народних депутатів України» (17 листопада 2011 p.). URL: https://zakon.rada.gov.ua/laws/show/4061-17

4. Лєліч М. Повз Раду: чим займуться партії та їхні лідери, що не потрапили в новий парламент. URL: https://www.rbc.ua/ukr/news/mimorady-zaymutsya-partii-lidery-popavshie-1564863190.html

5. Манайло-Приходько Р. Вплив «установчих» виборів на еволюцію партійної системиУкраїни. Гілея: науковий вісник. Збірник наукових праць. К.: «Видавництво «Гілея», 2018. Випуск 135. С. 362-367.

6. Мироненко В. «Украинский транзит» 2. Научно-аналитический вестник Института Европы РАН. 2019. № 4. С. 21-26. 
7. Остапець Ю. Еволюція партійної системи України в умовах трансформації соціальних і політичних структур. Ужгород: ЗІППО, 2016. $252 \mathrm{c}$.

8. Остапець Ю. Електоральні процеси в Україні: загальнонаціональний та регіональний виміри. Дисертація на здобуття наукового ступеня доктора політичних наук (23.00.02 - політичні інститути і процеси). Львів, 2016. 550 с. URL: http://www.lnu.edu.ua/wp-content/ uploads/2016/11/dis_ostapets.pdf

9. Офіційний сайт Центральної виборчої комісії. URL: http://www.cvk.gov.ua

10. Партійна система України до і після Майдану: зміни, тенденції розвитку, суспільні запити. Національна безпека і оборона Украйни. 2015. № 6-7. $180 \mathrm{c}$.

11. Рябчук М. Випробування виборами.URL.: https://zbruc.eu/node/ 91268

12. Сухарина А. Хто, де і як голосував на виборах до Ради. URL.: https://dif.org.ua/article/bitva-pokolin-khto-de-i-yak-golosuvav-na-viborakh-do-radi

13. Трансформація партійної системи: український досвід у європейському контексті / За ред. Ю. Якименка. Київ: Центр Разумкова, 2017. $428 \mathrm{c}$.

14. Туровский P. Национализация и регионализация партийных систем: подходы к исследованию / Р. Туровский. Полития. 2016. № 1. C. $162-180$.

15. Фесенко В. Дневник парламентских выборов - 2019: финал. URL: https://blogs.pravda.com.ua/authors/fesenko/

\section{Information about the author:} Ostapets Yu. O., Doctor of Political Science, Professor at the Department of Political Science and Public Administration, Dean of the Faculty of the Social Sciences,

Uzhgorod National University 14, Universytetska str., Uzhhorod, 88000, Ukraine 


\section{FORMATION OF "INFOSTAT UKRAINE-POLAND" TRANSBOUNDARY CLUSTER - IMPORTANT FACTORS OF PROGRESSION AND PERIFERATIONS OF POLAND-SLOVAK-UKRAINIAN BORDER}

\section{Palinchak M. M.}

\section{INTRODUCTION}

Due to the growth of globalization, the countries' governments keep playing a determinative role in the stimulation of developing rational policies concerning progress and making necessary institutions for the realization of their policies. In his monograph "Clusters in the global economy", S.I. Sokolenko notes: "Government plays quite a specific role in the course of creation and improvement of network structures of clusters. Here rather important is an active governmental policy on the formation of efficient foreign relations, as well as the development of collective actions in different spheres of the economy with the use of information technology"1. The further cited leading national scientist on problems of clustering states that the role of the government in this spheres is difficult to overestimate since $^{2}$ :

- firstly, it is to level the imperfections, existing in the market economic system, which can cause constraints on innovation and hinder clustering...;

- secondly, state efforts are necessary to achieve a positive external effect from the implementation of $R \& B$ (research \& business) results, especially when they are the outcomes of work of alliances or clusters;

- thirdly, the desire to obtain a much higher economic profit rate from the efforts made in government research is another reason for a government to promote the occurrence of clusters;

- fourthly, the desire to strengthen business activity in the country or region in high-tech (high technology) branch is another factor in the development of clustering.

In the scientific article "Cluster policy of the European Union", Doctor of Economics, Professor V.I. Chuzhikov and the Ph.D. in Economics, associate professor O.D Lukyanenko note that "the evolution of categorical and methodological apparatus of the theory of clusters started in the $19^{\text {th }}$ century with

${ }^{1}$ Соколенко C.I. Кластери в глобальній економіці / C.I. Соколенко. - К.: Логос, 2004. - C. 181.

2 Зазначена праця. - С. 184, 185. 
the advantages of the formation of agglomerations in economic activity considering some specialization and the availability of skilled labor, which were described by A. Marshall. Agglomerative ideas were supported in the $20^{\text {th }}$ century by J. Schumpet, who expressed an idea of "accumulation" or clustering of industry... An important contribution to the new understanding of clusters was made by famous Western researches J. Harrison, R. Sabella, and M. Porter"3.

Further on, the cited above scientists claim that:

- a new impulse in the research of clusters, in particular in the EU (in the context of intensifying crisis in the integration union) was made by the attempts of the European Commission (EC) to maximize the essence of the common technological policy, which was often viewed through the prism of competitiveness of innovative structures;

- among the latest publications, one should use the research of R. Martin and P. Sansley, who pay attention to the life cycle of the cluster, J. Rarra, who analyzed features of spatial-cyclic modeling of clusters, as well as national scientists M. Khmary and V. Kulyavets studied out the features of the development of some clusters in the EU. Today the issues of the efficiency of the realization of European Union policies, features in the presence of cross-country imbalances and asymmetries, uprising global instability became more active;

- besides, it becomes evident that the EU-tested cluster development models need to be applied for innovation and investment development in Ukraine. In this context, the following tasks need to be addressed above all:

1) identifying the nature and features of modern cluster development;

2) establishment of criteria for sectoral diversification of cluster models in the EU;

3) valuation of the nature of the institutional model of EU cluster policy.

\section{Scale of clustering in the world economy}

The most active supporter of the cluster model of development in the world economy is considered to be M. Porter, who offered several interpretations of this phenomenon. Let us mention one of M. Porter's definitions in which he already starts understanding clusters as “... a system of interconnected firms and institutions, which is more than just an amount of its constituent elements" 4 .

V. I. Chuzhikov and O. D. Lukyanenko also mention that quite an interesting industry relationship between clusters in the EU was established by

\footnotetext{
3 Чужиков B.I. Кластерна політика Європейського Союзу / В.І. Чужиков, С.Д. Лук'яненко // Економіка України. - 2013. - № 2 (615). - С. 81-91.

4 Чужиков B.I. Кластерна політика Європейського Союзу / В.I. Чужиков, С.Д. Лук'яненко // Економіка України. - 2013. - № 2 (615). - С. 83; Портер М. Международная конкуренция / М Портер. - М.: Международные отношения, 1993. - 896 с.
} 
national researcher V. Kulyavets, who succeeded in calculating the proportion of food clusters in the overall structure. Thus, in the general number of clusters in the EU the leading positions are taken by Germany, Italy, France, Sweden, Denmark, Finland that overtake $66,5 \%$ of all created in the EU clusters, but among food clusters, which traditionally are considered to be low-tech ones, the leadership belongs to Italy and France. Austria, Germany, Belgium, Finland, Poland, where 64 out of 82 clusters or $78 \%$ of all food clusters in the European Union are located, are far behind the leaders. Herewith the portion of Italy exceeds $30 \%$. Leadership as to foodstuff output (winery, butter and cheese making, meat sectors of national production) in the cluster system of the EU is a notable advantage for Italy and France, where the specific weight of created food clusters is almost $50 \%$.

The scientists cited above also affirm that during the financial crisis of 2008-2009 the rate of decline in the production of food industry of the European Union was identified at the level of $4 \%$, but they were not as drastic as in the innovative clusters of production (at 10-15\%). Herewith one should take into account that such giants of the European food cluster business as "Nestle", "Heisken", "Unilever", "Danone", "Laktiale" most actively used the cluster advantages during the crisis".

The scale of clustering in the world economy is increasing. According to the information given by the Cluster Observatory, there are more than 3 thousand clusters in the EU, in which more than $40 \%$ of working labor is used. Cluster statistics for individual EU countries are presented in Table 1.

Table 1

Cluster statistics for individual EU countries ${ }^{6}$

\begin{tabular}{|l|c|l|c|}
\hline \multicolumn{1}{|c|}{ Countries } & $\begin{array}{c}\text { Number of } \\
\text { clusters }\end{array}$ & \multicolumn{1}{|c|}{ Countries } & $\begin{array}{c}\text { Number of } \\
\text { clusters }\end{array}$ \\
\hline Great Britain & 168 & Netherlands & 20 \\
\hline Germany & 32 & France & 96 \\
\hline Denmark & 34 & Finland & 9 \\
\hline Italy & 206 & Poland & 161 \\
\hline Total & 440 & Total & 286 \\
\hline For reference: USA & 380 & & \\
\hline
\end{tabular}

5 Чужиков B.I. Кластерна політика Європейського Союзу / В.І. Чужиков, С.Д. Лук'яненко // Економіка України. - 2013. - № 2 (615). - С. 86.

${ }^{6}$ Марчук О.И. Кластерная стратегия инновационного развития экономик Беларуси и Украины / О.И. Марчук, Т.А. Яшева, Н.Т. Рудь / Проблеми інноваційного розвитку економіки України: Збірник наукових праць з актуальних проблем економічних наук // Наукова організація «Перспектива». У 2-х частинах. - Дніпропетровськ: Видавничий дім «Гельветика», 2014. - Ч. 2. - 312 с. 
According to the information given by the Cluster Observatory, which is presented in Table 1, the general number of clusters in the analyzed group of the EU countries amounts 726 units, of these, Italy has 206 units (the first place among the analyzed countries), the second place is taken by Great Britain (168 units), the third- by Poland (161 units) and the fourth- by France (96 units).

The leadership of Italy in the development of territorial cooperation is mentioned in several scientific sources. In particular, the economy of many regions of this country is formed as a cooperative network of "industrial districts", which, as mentioned by S.I. Sokolenko, creates a special way of public life. The cited scientists affirm ${ }^{7}$ that:

- In his famous book "The Third Wave" Alvin Toffler named "industrial districts" (further ID) of Italy "the wave of the $21^{\text {st }}$ century";

- it is also significant that the popularity of these structures in the world became so great that, before becoming President of the USA, Bill Clinton in 1992 traveled on purpose to Emilia Romagna to get acquainted with this "economic wonder";

- hundreds of books and tens of conferences are dedicated to "industrial districts";

- Italy is considered to be a classic country of small businesses. More than 4 million firms are registered in it, out of which only $2 \%$ are considered to be big, that is to have 1000 or more employees. The majority of firms belong to small ones (up to 100 employees) and very small (up to 20 employees);

- as defined by the Italian Institute of Statistics (ISTAT) "industrial district" is an economic unit on a local territorial basis, where communities of people and several medium-sized small enterprises that take part in the same production process, interact. In other words, these are clusters in Italian;

- There are more than 260 "industrial districts" in Italy, with more than 80,000 people involved. If we add to these enterprises related enterprises and enterprises located in the territories of other districts, including the sphere of services, we can say that more than 1.2 million of small and medium-sized enterprises are operating in the ID. The number of employees at these enterprises varies from 4 to 6 million people. Most ID are mono-sectoral. Most of them are concentrated on the production of clothing or textiles (70), furniture and household goods (40), machine tools and other equipment (32), footwear and leather goods (27), food (17), jewelry (4) and other products. (10).

A comparative analysis of Table 1 data and S.I. Sokolenko's monograph "Clusters in the Global Economy" shows significant differences in the presence of clusters ("industrial districts") in Italy. It should be noted that at the initiative

${ }^{7}$ Соколенко C.I. Кластери в глобальній економіці / C.I. Соколенко. - К.: Логос, 2004. - C. 207, 209. 
of the Minister of Forestry of the Ukrainian SSR Grunyanskiy I.I., a native of the Transcarpathian region, in the regions of the Ukrainian Carpathians, there were created forestry plants, many of which were functioning as clusters. In particular, in the Transcarpathian region the production of furniture sets at Svalyava Forestry Plant, Mukachevo Furniture Factory, Teresvyansky Woodworking Plant, Kostrynsky Kitchen Furniture Factory was established. In addition, workshops for the production of wood-chip boards for furniture enterprises in the region and many enterprises of Ukraine operated in the Svalyava Forestry Plant and Teresyansky Woodworking Plant. Therefore, the experience of Italy in clustering its economy is of great importance for the restoration of cluster type furniture complexes in the Transcarpathian region and the creation of new clusters.

Germany is one of the leading technology creators in the world and the largest technology provider in Europe. According to scientific sources, the latest technologies and globalization have changed the world and the nature of economic competition, which has taken on new forms. Basically, these changes concern the ways of generating, transferring and adapting knowledge. Knowledge in modern conditions is recognized as the basis of productivity and economic growth. The engine of knowledge and economic development is information. The efficiency of country's innovation system and its potential used for improving economic growth play a major role in the transmission and use of information. It is no coincidence that Germany has significant competitive advantages in technology and know-how. In this regard, it should be noted the successes and importance for the German and world economy of German $\mathrm{FRG}^{8}$ clusters, as stated in their speeches by representatives or executives of leading German companies at the German-English Forum in September 2003, noting:

1. About the significant success of the clusters of Munich in the field of information technology and in the opinion of von Peter, Munich in this is almost equal to the Silicon Valley (USA) and similar clusters of Greater London:

1.1) The head of Siemens also said that the European Union should shift its industrial policy towards a significant increase in innovation and research costs, as well as provide opportunities for small and medium-sized companies to master the best technologies and approaches in the work within the regional clusters of relevant types of business;

1.2) The European industrial policy must be reformed, first and foremost, by significantly improving the EU patent system, which is 8 times

${ }^{8}$ Соколенко С.I. Кластери в глобальній економіці / C.I. Соколенко. - К.: Логос, 2004. - C. 470-472. 
more expensive under the current conditions and has a more complex registration system than that operating in the US. According to von Pierre, CEO of Siemens, the competitiveness of European production is also reduced due to the high cost of labor. The aforementioned circumstances are forcing the European manufacturers to seek low-cost countries for the corresponding production processes, which causes relocation of production to Asian countries, especially to China. This leads to paralysis of many outsourcing industries;

1.3) Siemens, the sixth largest manufacturing company in the world, has radically changed its market behavior strategy over the past few years, focusing its market operations not only outside Germany but also outside Europe. The German market part in the supply of Siemens products in the last 2-3 years is no more than $25 \%$ of the total sales. According to von Pierer, both Siemens and other European manufacturers need to significantly increase research costs and, first and foremost, in the field of nano- and biotechnology, in order to secure their priorities in the world markets. At the beginning of the $21^{\text {st }}$ century. Germany spent only $2,5 \%$ of total GDP on it, which secured it only $7^{\text {th }}$ place in the world ranking;

1.4) The main recommendation to get out of depression is a need for all EU governments to fully support the development of cluster structures consisting of small, medium and large companies tied to specific territories and regions. Moreover, the EU strategy should focus on the development of networked cluster structures and stimulate innovation, as well as ensure the training of skilled workforce with active involvement of local universities in this process.

2. Another high-tech star is the high-tech cluster in Hamburg, with media start-ups taking the lead.

Internshop specializing in e-commerce software development became the most well-known here. The company's shares are listed on both the Frankfurt Stock Exchange and the largest stock exchange in the world, Nasdag. Although the company was partially hit by the economic downturn of 2001 in the IT sector, it still retains its leading position in the cluster and continues to be an example for local businesses.

3. The third new star in high technology is the high-tech cluster in Dresden. It is known not only for its technical university, which has over 22,000 students studying in 66 different specialties. The Dresden Cluster also includes the Siemens Technology Center manufacturing chips and panoramic cameras ... As it became known, the high-tech AMD (USA) cluster, realizing the benefits of the Dresden cluster and the city's proximity to Eastern European markets, created a manufacturing company here of semiconductors by investing DM 2.9 billion in its development. In Germany, a variant of the "third way" was implemented, a distinctive feature of which became its national orientation 
at openness to the global economy. Due to this, a rather high level of competitiveness increase and the country's readiness to create networks were achieved. Thus, in 2001, Germany ranked: in the country's credit rating $2^{\text {nd }}$ place, and in the quality of business environment $-4^{\text {th }}$ place ${ }^{9}$.

\section{Experience of economy clustering and possibility of its use for economy of Ukraine}

Germany's experience in clustering its economy represents both scientific and pragmatic value for Ukraine and its regions in the Ukrainian part of the Carpathians with regard to the system and management of the German Protected Areas. In particular, Ph.D., prof. F.D. Gamor notes that at the meeting of the UNESCO World Heritage Committee, held on June 19-29, 2011 in Paris, the decision was made to expand the Ukrainian-Slovak object "Beech forests of the Carpathians" by five new clusters of Germany with an area of 4391 ha. They form the German part of the territory of four national parks (Yasmund, Muritz, Chaynih and Kellerwald-Edersee) and the Schorfheim-Corin Biosphere Reserve. The new name of the object has also been approved: "Carpathian beech forests and ancient beech forests of Germany" (Slovakia, Ukraine, Germany). At the same 35th meeting of the World Heritage Committee in Paris, there was proclaimed that the "Ancient Forests of Germany" was included in the UNESCO World Heritage Lists within the existing Ukrainian-Slovak object "Beech Forests of the Carpathians". The success of the German colleagues is due to the active support of the staff of the Carpathian Biosphere Reserve and personally F.D. Gamor, who participated in numerous meetings, as well as a member of the expedition during the evaluation of the German clusters. Also during dominance, an integrated management system was developed to ensure the effective management of this extremely valuable tripartite transnational entity $^{10}$. It should be noted that in the Heinik National Park the regime of protection and use of natural complexes is very similar to the protected regime in the Ukrainian nature reserves. It employs 63 professionals, including 25 rangers, with considerable experience in conserving natural ecosystems. Scientific research and systematic monitoring of natural processes have been established. At the expense of the local community, a unique information and tourism infrastructure has been created here, in particular, the famous not only in Germany ecological trail in the crown of trees, which is visited annually by hundreds of thousands of guests. Over one decade of use, more than one billion

\footnotetext{
${ }^{9}$ WEF Knowhenge Nawigator - Germany, 2003 // http://www.wevorum.org.de

${ }^{10}$ Гамор Федір. Всесвітнє визнання букових пралісів Карпат: історія та менеджмент / Матеріали з нагоди десятиріччя утворення об'єкта Всесвітньої спадщини ЮНЕСКО «Букові праліси Карпат та давні букові ліси Німеччини». - м. Ужгород, Вид-во «ФОП «Сабов А.М.». -
} 2017. $-248 \mathrm{c}$. 
euros $^{11}$ have been deposited in the local budget. Thus, on the European continent a unique international association of border areas of world importance was created, with a total area of 96072.4 ha (core zone 33630.1 ha), which covers the natural range of forest spread from beech (Fagus sylvatica) from the highlands of the Ukrainian Carpathians to the Baltic Sea coast in the German Rügen ${ }^{12}$ archipelago. It is indisputable that the Ukrainian part of the site, consisting of the largest in Europe sites of beech forests of the Carpathian Biosphere Reserve and Uzhan National Nature Park within the Rakhiv, Tyachiv and Velikoberezniany areas, is almost $70 \%$ of its total area and is the only natural area an item in Ukraine that is on the UNESCO ${ }^{13}$ World Heritage List.

An important role in conservation plays an international cooperation of states on a bilateral basis, for example launched the project "Support to protected areas of Ukraine" for the use of German financial assistance for the development of nature reserves and national parks in Ukraine. In this regard, F. Hamor notes that on February 3, 2016, the Verkhovna Rada of Ukraine ratified a financial agreement between the Cabinet of Ministers of Ukraine and the Government of the Federal Republic of Germany on financial cooperation within the framework of the project "Support to the Protected Areas of Ukraine" dated April 10, 2015. The Ministry of Ecology and Natural Resources of Ukraine has been designated the recipient of the 14 billion euros allocated by the German Development Bank KFW. The main objective of the project is to improve the management status and success of selected reserves and national nature parks, enhance their cooperation with local communities, and increase the perception of the need to preserve the nature reserve fund in the public consciousness. The project is envisaged ${ }^{14}$ :

- direct costs, primarily to fund activities to develop infrastructure and strengthening material-technical base on eight sites of natural protected areas in the Carpathian region;

- 1.2 million euros will be allocated to support local communities in their area of activity;

- the project was officially launched on May 1, 2016 and will last 6 years until April 2020. Key partners in the implementation of the project are the Ministry of Natural Resources of Ukraine, administrations of the protected areas, representatives of local communities and public organizations,

${ }^{11}$ Гамор Федір. Всесвітнє визнання букових пралісів Карпат: історія та менеджмент / Матеріали з нагоди десятиріччя утворення об’єкта Всесвітньої спадщини ЮНЕСКО «Букові праліси Карпат та давні букові ліси Німеччини». - м. Ужгород, Вид-во «ФОП «Сабов А.М.». 2017. - C. 87.

${ }^{12}$ Гамор Федір. Зазначена праця. - С. 105.

${ }^{13}$ Гамор Федір. Зазначена праця. - С. $107 .$.

${ }^{14}$ Гамор Федір. Зазначена праця. - С. 131-134. 
specialized state institutions and selected through the international competition Consultant Consortium, which includes the German company "ATH GROUP AG", World Nature Foundation (WWF), the Frankfurt Zoological Society, the Ukrainian Society for the Protection of Birds and its contracting partners (suppliers of goods and services, construction companies, non-governmental organizations and auditors);

- a phased approach will be used to implement the project activities on the ground. In the first stage, it will be implemented in the Carpathian Biosphere Reserve and Gorgany Nature Reserve, with the gradual involvement of other priority nature conservation areas.

At the seminar of the Ministry of Nature of Ukraine October 10-11, 2016 on the report of the initial phase of the project "Support for nature reserves of Ukraine" project manager of the Department of Energy and Natural Resources of the German Development Bank KFW Frank Murschel said that, unfortunately, in Germany, providing financial assistance to Ukraine is not a priority in the field of nature protection. Therefore it is extremely important during this project to achieve tangible positive results in the development and preservation of natural reserve fund in order to open up new opportunities for further German environmental investment in Ukraine.

The seminar also discussed the possibilities of financing, at the expense of the project, the restoration of the Museum of Forests and Alloys and the completion of the Rehabilitation Center for brown bears and other infrastructural objects in the Synevyr National Nature Park and other nature conservation areas for which design and budget documentation is already established ${ }^{15}$.

The experience of Italian and German clustering enables to make a number of generalizations. First of all, the experience of these industrialized countries of G7 has a comprehensive understanding of the importance to comprehensive processes of globalization and regionalization. The value of this experience is the presence of different approaches to the regional approach strategy and to achieving positive results in world markets through the effective use of cluster formations based on advanced technologies. It should be noted that if in the Italian clustering scheme a strong economic result is achieved through the effective consolidation of the efforts of SMEs and other small forms of business, then in the achievement of the German model of clustering own large companies occupying leading positions in the world economy make an important contribution. Subsidiaries of large German companies operate in the regions of the Ukrainian Carpathians, and in the Transcarpathian region the leading position is occupied by CJSC Eurocar. Subsidiaries of large German companies operate in the regions of the Ukrainian Carpathians, and in the

\footnotetext{
${ }^{15}$ Гамор Федір. Зазначена праця. - С. 131-132.
} 
Transcarpathian region the leading position is occupied by CJSC Eurocar. Considering that the organizational and legal foundations of conducting a protected matter are defined by the Law of Ukraine "On the Nature Reserve Fund of Ukraine" (1992) and legislative acts in accordance with it, which is why the NRF of Ukraine is considered as an integral part of the world system of natural territories and objects under special protection. In order to intensify Ukraine's participation in international cooperation on the protection and rational use of territories and sites of the NRF, it is necessary to ${ }^{16}$ :

- intensify activities aimed at concluding multilateral and bilateral international agreements in the field of conservation;

- ensure the broad involvement of governmental and scientific institutions and non-governmental organizations in the implementation of international projects aimed at solving global environmental issues and developing conservation;

- create in the border areas interstate protected territories, especially nature reserves and national parks, to work with relevant international organizations the issue of better border nature reserves and national parks Ukraine biosphere status, activities of the Council of Europe with the award of the relevant diplomas;

- systematically analyze international experience in the development of nature conservation, conduct scientific forums and working meetings of Ukrainian experts in nature conservation with foreign colleagues;

- expand the training of Ukrainian conservationists abroad;

- promote the establishment of international and other conservation centers in Ukraine;

- enhance the participation of scientific institutions in the preparation of relevant international scientific publications;

- more actively promote international eco-tourism.

The above-mentioned requirements of the Prospects Program in Ukraine ("Reserves") are clearly implemented by the management of the Carpathian Biosphere Reserve. We will also note that the Council of Europe awarded the European Carpathian Biosphere Reserve with a European diploma for the first time in Ukraine for outstanding achievements in the preservation of the border, cultural and historical heritage. On 4 July 2006, the Reserve was visited by Council of Europe expert from the Polish Institute for Nature Conservation, Ministry of the Environment, Jadwiga Sinkevich. She has comprehensively analyzed the activities of the CBR, met with its director, prof. F. D. Gamor, visited the Chernogirsk, Uhol, Kevlov border research departments and gave a

${ }^{16}$ Екологія і закон. Екологічне законодавство України. У двох книгах. Книга 2; Відп. ред. акад. УЕАН В. І. Андрейцев. - К. : Юрінком Інтер. - 1997. - 574 с. 
high assessment of the Reserve stated that its activities meet all the requirements of the Council of Europe. At the end of September 2006, UNESCO expert David Mikhalik and Professor of Zvolen Forestry University (Slovakia) Ivan Voloschuk visited Rakhiv to assess the forests of the Carpathians. UNESCO expert noted the extensive work done by Reserve team on participation in the project "Beech forests of the Carpathians", which is of great state and political importance for Ukraine and our region ${ }^{17}$.

At the same time, it should be noted that there is no definition of the cluster category in both the Economic Encyclopedia ${ }^{18}$ and the Ecological Encyclopedia $^{19}$. S. I. Sokolenko's monograph "Clusters in the Global Economy" generalized long-term experience in studying clustering problems, clarifies the problems of self-sufficiency of cluster mechanisms that allow to overcome crisis phenomena, more effectively solve socio-economic problems both at the municipal and regional as well as national levels ${ }^{20}$. The above has already been mentioned about the role of German clusters in the territories and objects of ancient beech forests of the German Nature Reserve Fund, as well as about the unique information and tourism infrastructure, including the famous ecological path in tree crowns. However, even more interest in German nature conservation, forestry and other areas related to the activities of the Hainich National Park was caused by the Uholka Beech Forests. During September 1-4, 2015, guests from Germany studied with enthusiasm the patterns of functioning of the largest areas of beech forests in the world. They were particularly impressed by the five-hundred-year-old monumental beech trees, the karst bridge, and the wild, undisturbed condition of the Velika Uholka River Basin, which made the twenty-three-hour trek to the top of Mount Menchul and back ${ }^{21}$. Even this incomplete description of the Uholka beech forests gives us reason to declare the feasibility of creating a recreational and tourist cluster on the basis of the Uhol Forestry.

The inclusion of Carpathian beech forests in the UNESCO World Heritage List, according to the director of the Carpathian Biosphere Reserve,

${ }^{17}$ Гамор Федір. Зазначена праця. - С. 38.

${ }^{18}$ Економічна енциклопедія: [у 3 т.]. - Київ: Видавничий центр «Академія», 2002. / Голова редакційної ради: Гаврилишин Б. Д. (голова) [та ін.]. Т. 1 / [відп. редактор Мочерний С. В. та ін.]. $-2002 .-864$ c.

19 Екологічна енциклопедія: У 3 т. / Головн. ред. А. В. Толстоухов та ін. - К.: ТОВ «Центр екологічної освіти та інформації», 2007. - Т. 2: Є-Н. - 416 с.

${ }^{20}$ Соколенко С.І. Кластери в глобальній економіці / C.I. Соколенко. - К.: Логос, 2004. - C. 2.

${ }^{21}$ Гамор Федір. Всесвітнє визнання букових пралісів Карпат: історія та менеджмент / Матеріали з нагоди десятиріччя утворення об’єкта Всесвітньої спадщини ЮНЕСКО «Букові праліси Карпат та давні букові ліси Німеччини». - м. Ужгород, Вид-во «ФОП «Сабов А.М.». 2017. - C. 87. 
prof. F. D. Humor, on the one hand, opens up new opportunities for intensifying ecotourism activities, but on the other hand, it places increased demands on the protection and carrying out of more efficient and large-scale educational work and development of the necessary tourist infrastructure. The expert opinion of the International Union for the Conservation of Nature (IUCN) also emphasizes the fact that high levels of unemployment are observed among the local population (especially in rural areas), and many people go abroad for work. Wood is being harvested in the buffer zone for fuel, which is now impossible to stop. The local population, unfortunately, is not always aware of the difference between old-grown and commercial forests. Here, further unauthorized harvesting and irresponsible behavior of tourists (arson, clogging, poaching, etc.) are possible here. There are also possible unauthorized deforestation and irresponsible behavior of tourists (arson, clogging, poaching, etc.). Therefore, the World Heritage Special Recommendations provide for an integrated management plan to implement measures aimed at addressing these issues. It is also recommended to seek additional sources of funding, involve local residents, NGOs and all interested parties. It is no coincidence that the book "The World Recognition of the Beech Forests of the Carpathians: History and Management" emphasizes ${ }^{22}$ :

- in this connection it is very important to take care of job creation in the adjacent to old-growth forests settlements, first of all, through the construction of hotels, restaurants and other infrastructure, to introduce alternative types of household heating (due to gasification or creation of technical and economic conditions for electricity use in Rakhiv and Tyachiv districts), asphalting of roads leading to primeval forests (especially in Mala Uholka), etc.

- in order to intensify scientific and ecological and educational work, an International Ecological and Educational Center "Beech Forests of the Carpathians" should be established in Rakhiv;

- powerful information objects should also be built in Mala Uholka, Velika Uhla, Shyrokyy Luh and other arrays;

- solving of these and other problems is possible only with the adoption of a special resolution of the Cabinet of Ministers of Ukraine and financial support of international organizations.

The historic Mukachevo Conference, held from 13 to 17 October 2003, under the auspices of the Council of Europe, the World Wildlife Fund (WWF), the International Union for the Conservation of Nature (IUCN) and the International Union of Forestry Research Organization (IUFRO), played an important role in the conservation and study of Europe's beech forests. The Carpathian Biosphere Reserve and the Swiss Federal Institute for Forest, Snow

\footnotetext{
${ }^{22}$ Гамор Федір. Зазначена праця. - С. 41.
} 
and Landscape Research were the direct organizers of this conference. At this conference, Mukachevo's statement and appeals were adopted ${ }^{23}$. In particular, the statement sets out a general picture of the state of natural forests in the temperate zone of Europe. At the same time, the central task for scientists and environmentalists should be to study their structure, dynamics of growth, biodiversity and socio-economic values, as well as problems of their protection.

The Mukachevo Conference, attended by about 250 representatives of forest science from 26 countries, appealed to all interested parties to inventory forests and natural forests on the basis of unified methods, to intensify scientific research and monitoring in order to use the data obtained in practical forestry education, etc.

Of particular significance was the grand opening on June 7, 2013, in the village of Mala Ugolka, Tyachiv district of the information-tourist center "Beech forests - UNESCO World Heritage Site". According to the leading scientist of the CBO Victoria Bundyak, this object "was created on the initiative and under the direct supervision of Professor Fyodor Gamor, who together with a group of specialists of the reserve developed his thematic-exposition plan, design and informational content..." A special highlight is the exhibition hall, which creates the illusion of being in a beech forest. Banner wallpapers reflect the age-old beech trees, covered with ivy garlands, the old forest cuts through the mountain stream, animals from the Carpathian forests meet curiously from outside the trees. The famous Karst Bridge of Ugolka seems to hang over the visitors in all its greatness, and birds float beneath the ceiling, decorated by the blue sky. Here, in the silence of the simulated beech forest, visitors can watch videos of the ancient Carpathian beech forests. From this hall visitors are fascinated by the mystery and greatness of the beech primeval forest, amazed and convinced of the need to preserve $\mathrm{it}^{24}$.

Of scientific interest is a comparative analysis of the dynamics of the Gross Domestic Product (GDP) growth (decline) for the four EU countries belonging to the G7 (UK, Italy, Germany, France) and the Carpathian Euroregion countries which was established in 1993. It included Hungary, Poland, Ukraine, Slovakia, and later Romania. The purpose of the Carpathian Euroregion is the coordination of economic and foreign economic activity, creation of favorable conditions for integration ${ }^{25}$. The data of such analysis on the dynamics of growth rate (GDP decline) for the period from 2008 to 2017 in the context of the above mentioned countries is reflected in Table 2.

\footnotetext{
${ }^{23}$ Гамор Федір. Зазначена праця. - С. 72, 73.

${ }^{24}$ Гамор Федір. Зазначена праця. - С. 78.
}

${ }^{25}$ Розміщення продуктивних сил: Підручник / В.В. Ковалевський, О.Л. Михалик, В.Ф. Семенова. - 3-тє вид., випр. і доп. - К.: ТОВ «Знання», КОО, 2001. - 353 с. - (Вища освіта XXI ст. ). 
Table 2 shows that the global financial crisis of 2008-2009 had a negative impact on the European group of countries of the Big Seven. These countries have been members of the European Union since its formation in 1992. In the United Kingdom, Italy and France, crisis phenomena have negatively affected rates of GDP decline in 2008-2019 and in Germany in 2009. Subsequently, in the analyzed group of countries, a declining trend in GDP emerged in Italy in 2012-2013.

Table 2

Gross Domestic Product Growth (Decrease) Rate for the Analyzed Group of Countries from 2008 to 2017 (2008-2009 by the Purchasing Power Parity (PPP) of 2005, 2010-2017 by the PPP of 2010; percent to the previous year)

\begin{tabular}{|l|c|c|c|c|c|c|c|c|c|}
\hline $\begin{array}{l}\text { Groups of } \\
\text { countries }\end{array}$ & $\mathbf{2 0 0 8}$ & $\mathbf{2 0 0 9}$ & $\mathbf{2 0 1 0}$ & $\mathbf{2 0 1 2}$ & $\mathbf{2 0 1 3}$ & $\mathbf{2 0 1 4}$ & $\mathbf{2 0 1 5}$ & $\mathbf{2 0 1 6}$ & $\mathbf{2 0 1 7}$ \\
\hline $\begin{array}{l}\text { I. The EU's G7 } \\
\text { countries }\end{array}$ & & & & & & & & & \\
\hline United Kingdom & $-1,0$ & $-4,0$ & 1,7 & 1,5 & 2,1 & 3,1 & 2,3 & 1,9 & 1,8 \\
\hline Italy & $-1,2$ & $-5,5$ & 1,7 & $-2,8$ & $-1,7$ & 0,1 & 1,1 & 0,9 & 1,5 \\
\hline Germany & 1,1 & $-5,1$ & 4,1 & 0,5 & 0,5 & 1,9 & 1,7 & 1,9 & 2,2 \\
\hline France & $-0,1$ & $-3,1$ & 1,9 & 0,3 & 0,6 & 1,0 & 1,1 & 1,2 & 2,2 \\
\hline $\begin{array}{l}\text { II. Carpathian } \\
\begin{array}{l}\text { Euroregion (CE) } \\
\text { countries }\end{array}\end{array}$ & & & & & & & & \\
\hline Poland & 5,1 & 1,6 & 3,6 & 1,6 & 1,4 & 3,3 & 3,8 & 3,0 & 4,6 \\
\hline Romania & $-6,1$ & $-1,1$ & $-2,8$ & 1,2 & 3,5 & 3,1 & 4,0 & 4,8 & 6,9 \\
\hline Slovakia & 5,8 & $-4,9$ & 5,0 & 1,7 & 1,5 & 2,8 & 3,8 & 3,3 & 3,4 \\
\hline Hungary & 0,9 & $-6,8$ & 0,7 & 1,6 & 2,1 & 4,2 & 3,4 & 2,2 & 4,0 \\
\hline Ukraine & 2,3 & $-14,8$ & 4,1 & 0,2 & 0,0 & $-5,6$ & $-0,8$ & 2,4 & 2,5 \\
\hline
\end{tabular}

* Grouped by source ${ }^{26}$

Among the countries of the Carpathian Euroregion bordering Ukraine, the longest rates of GDP decline during 2008-2010 were in Romania and in Slovakia and Hungary only in 2009. The largest GDP decline among the two analyzed groups of countries in 2009 was observed in Ukraine (-14.8). In 2014-2015, Ukraine again experienced negative trends in GDP decline $(-5.6 \%$ and $-0.8 \%$ respectively).

At the same time, among the group of countries of the Carpathian Euroregion, the experience of Poland and the activities of the Government of

${ }^{26}$ Статистичний щорічник України за 2012 рік / Державна служба статистики України. - Київ: ТОВ «Август-Трейд». - 2013. - С. 535, 536. Статистичний щорічник України за 2017 рік / Державна служба статистики України. - Київ: Державне підприємство «Інформаційно-аналітичне агентство». - 2018. - С. 525, 526. 
this country deserve attention, since the crisis phenomena of the global financial crisis, as can be seen from Table 2, did not appear here, and on the contrary the GDP growth in 2008-2009 was 5.1\% and $1.6 \%$.

Sokolenko claims that in New Europe, Poland is well known in modern economic history for being one of the countries of the socialist community to strongly reject the proposed palliative forms of market socialism and has set out to create a full-fledged market economy in the country. It was Poland who was the first country to legislate on a program of market reforms after the Tadeusz Mazowiecki government of Solidarity formed in 1989. On January 31, 1990, a program of radical reforms designed by a team of economists under the leadership of Lelec Balcerovich, who, as Vice Prime Minister, led the implementation of the economic transformation program, later known as "shock therapy" began ${ }^{27}$. Noting Poland's progress in transforming its economy, Sokolenko states that success has largely been achieved thanks to the activity of SMEs and the start of clustering... SMEs provide about 50\% of Poland's GDP, $50 \%$ of exports and $60 \%$ of country's imports ${ }^{28}$. The quoted domestic scientist states that in addition to rather modest local budgets, sources of financing for network structures of SMEs, clusters and individual firms in Poland also include foreign investments and loans, voluntary contributions and international technical and economic assistance ${ }^{29}$.

According to the United Nations Economic Commission for Europe (UN / ECE) and national statistics of countries, Poland exceeded GDP of 1989 in 1995, Slovakia in 1998, Hungary in 2000. In 2001, the average GNP of CIS countries was still $40 \%$ lower than the corresponding level of 1989 , and for some countries, including Ukraine, the GNP of 2002 was less than half of the volume produced over ten years ago. The governments played a significant role in the success of these countries. They were able to use the most effective methods of establishing a dialogue between the public and private sectors in various aspects of trade, investment, transport, energy network, environmental protection and industrial cooperation. And yet, the most significant contribution was made by these governments to the institutionalization of the market environment in their countries. It is also worth noting that:

- Poland's success in transforming its economy was largely achieved through SMEs and the start of clustering, with annual GDP growth of over 5\% in the 1990s, which was the highest among Central European countries that became EU members in $2004^{30}$;

${ }^{27}$ Соколенко C.I. Кластери в глобальній економіці / C.I. Соколенко. - К.: Логос, 2004. - C. 315.

${ }^{28}$ Соколенко С.I. Зазначена праця. - С. $318,319$.

${ }^{29}$ Соколенко C.I. Зазначена праця. - С. 322.

${ }^{30}$ Соколенко C.I. Зазначена праця. - С. 318-319. 
- economic transformations in Hungary, as in Poland, were carried out on the basis of clustering. In particular, in the early 1990s, industrial parks (IPs) began to be actively created in Hungary, which, based on the model of such IPs in industrialized countries, emerged from the initiative of local administration and business circles. In the early 2000s, more than 100 IPs were operating in all regions of Hungary, bringing together 656 companies with 60,000 employees. The dynamic activity of the IPs has become the basis for the intensification of the creation and development of clusters in Hungary. Western Pannonia has the leading position in the clustering process among Hungary's seven regions. The greatest pride of this region is the dynamic development of the Pannonia Business Initiative program, which has become a model of regional integrated economic development for Hungary. The development of the PANAC automotive cluster became the core of this program. At the same time, PANFA's woodworking and furniture manufacturing, electronics and tourism, related to thermal mineral water, clusters are being developed. The activities of these clusters are being deployed within the framework of a common regional platform supported by the Regional Development Agency and a regional holding, which includes three enterprise development funds, county labor centers, as well as a network of industrial parks in Western Pannonia ${ }^{31}$;

- Slovakia's compliance with the conditions for accession to the European Union was complicated by the fact that it, like other CEE countries, had to solve complex problems of democratization and transition to a market economic system during this period. These problems were connected with privatization of state property and restructuring of the banking system, creation of a system of local self-government, reforming of the judicial system, etc. The Association Agreement between the European Union and its Member States, on the one hand, and the Slovak Republic (SR) as a sovereign state after the division of Czechoslovakia into two independent states, on the other, was signed at the highest level on 4 October 1993 in Luxembourg. Article 1.2 of the Association Agreement with the Slovak Republic outlines its specific goals ${ }^{32}$ :

1. Create the necessary conditions for political dialogue that will foster close political relations between the parties of the treaty. The dialogue should facilitate the process of full integration of the SR into the EU. It will primarily address security, as well as the gradual convergence of positions of the two sides on international issues. In addition, the EU is committed to fostering close relations between the CEE countries as a whole and the Visegrad countries in particular.

${ }^{31}$ Соколенко С.I. Зазначена праця. - С. 302, 304, 308.

32 Україна в системі європейської інтеграції [текст]: Монографія. Навч. посібник / М. Палінчак, В. Приходько, В. Химинець та ін. - Ужгород: ТОВ «РІК-У», 2016. - 344 с. 
2. Promote trade and harmonious economic relations between the Parties and thereby promote the dynamic development and prosperity of the Slovak Republic.

The achievements of industrial Slovakia's clustering look a little more modest than those of its neighbors, Poland and Hungary. At the same time, points of high investment activity in the Ukrainian-Slovak border have formed, which need the support of the governments of both countries, in particular in such economic activities as ${ }^{33}$ :

- the development of tourism and recreation, the protection of the natural environment are considered by the bodies of state executive power and local self-government in the border regions of Ukraine and Slovakia as priority areas of activity and cross-border cooperation. Previous experience, the presence of a network of international, national and regional programs in this field make it possible to consider the creation of an international TatranCarpathian tourist-recreational cluster and a congress-tourism center at the Ukrainian-Slovak border. This project can be realized as a result of active activities of business circles, tourist and sports organizations of Slovakia and Ukraine, which could most accurately apply their experience and technologies acquired during the Tatras Universiade, other competitions in winter sports of high world and European levels. Such cooperation could give a very effective result for the development of the border regions of both countries;

- implementation of objective prerequisites for the formation of a large-scale international transport and logistics complex with the development of a system of logistics warehouses in the territory of Slovakia, an industrial park in the Ukrainian territory and a new bridge crossing the Tisza river;

- construction of railway crossing in the area of stations Pavlovo (Ukraine) - Matyovce (SR), where there is a wide track between stations Uzhgorod - Kosice, in the immediate vicinity of which from the Ukrainian side the territory of perspective development of electronic and auto agrarian industry is started and reconstruction of export lines of high voltage power grids is carried out.

Cluster model economic development in industrialized and European countries with transition economies is directly linked to logistics, an industry of science that studies the theory of active management of material, information, and financial flows in economically adapted synergistic systems.

Romania, the southwestern neighbor of Ukraine, as well as other countries with transition economies, has faced serious problems of entrepreneurship development in the country, leaving the country's economic

33 Україна в системі європейської інтеграції [текст]: Монографія. Навч. посібник / М. Палінчак, В. Приходько, В. Химинець та ін. - Ужгород: ТОВ «РІК-У», 2016. - С. 240, 241. 
situation for 10 years (1989-1999) quite complicated and fragile. During this period, seven different governments have changed in Romania. Each change of the Cabinet caused not only changes at its level, but also led to the shuffling and rebuilding of the entire leading level in the ministries and state agencies. All this caused considerable delays and even the cancellation of individual National Programs. The new government, elected in 2000, drew attention to the development of the SME sector. At that time, for the first time, not only in Romania but also in Europe, the Ministry of Small and Medium-Sized Enterprises was established, and in July 2000 the National Agency for Regional Development (NARD) was set up to develop a variety of local initiatives. However, significant changes have taken place at the new NARD agency, which has been actively involved in the process of privatization and restructuring and overcoming bureaucratic barriers on the path of foreign direct investment. In particular, at the end of 2001, more than 100 BAC (Business Activity Centers) were established across the country, providing a wide range of services, at the initiative of the NARD. BAC provide business plans, entrepreneurship training, grants and loans to SMEs. In accordance with the objectives set, a National Regional Development Plan was established and approved in Romania, which has the following components ${ }^{34}$ :

- clarification of property rights;

- introducing corrections to ensure consistency of economic legislation;

- establishing the necessary institutions, ensuring financial discipline;

- a stable tax system and elimination of bureaucratic obstacles;

- control of the budget deficit;

- Strengthening of operating expenses and increase of efficiency of budgetary expenses;

- fighting inflation;

- support for products made with the "made in Romania" brand to succeed in world markets;

- Increasing competitiveness in various industries;

- agricultural development;

- infrastructure development and environmental protection;

- more efficient use of tourism potential;

- consolidation of the SME sector;

- maximum use of manpower;

- territorial planning and regional development.

${ }^{34}$ Соколенко C.I. Зазначена праця. - С. 338-340. 


\section{CONCLUSIONS}

Thus, according to Sokolenko in his monograph "Clusters in the Global Economy", the National Regional Development Plan reflected the country's main strategic priorities: standards;

- legislative and institutional harmonization with EU regulatory

- practical tools for structural regulation, enhancement of regional and national competitiveness and many other relevant areas for the regions;

- raising the economy of less developed regions to the level of the most developed western regions of Romania. The Ministry of Development and Forecasting of Romania is responsible for controlling and monitoring the National Regional Development Plan;

- in order to accelerate the development, the Romanian side, together with neighboring countries, Hungary and Bulgaria, provides for the implementation of joint border cooperation initiatives. There are also similar types of cooperation between Romanian and Ukrainian border areas in the Tisza river basin.

The clustering of the Romanian economy is slow because of the significant difficulties in the formation and development of SMEs, as former governments have traditionally focused on the problems of "white elephants" large unprofitable state-owned enterprises. Of great importance in the development of network structures was the project "Alliance for entrepreneurial development in rural zones", carried out in Alba Julia, in mountain Transylvania, which was joined by the previously established Italian cluster in Calabria. Italian-Romanian cooperation at the regional level demonstrates the perspective and effectiveness of sharing experience and transferring knowledge on business development and overcoming the crisis in the most depressed areas (in 2001, the Ukrainian Podillya, Hrytsiv used this experience, creating the first ecological cluster in Ukraine) ${ }^{35}$. Such experience is valuable for the regions of Ukraine, in particular for the regions of the Ukrainian Carpathians, as well as the Transcarpathian region.

\section{SUMMARY}

The article analyzes the concept of "cluster". The role of clusters in economic development. Features of clustering of the world economy. Features of cluster development in the period of the world economic crisis. Experience of clustering the economies of different countries. And the possibility of its use for the economy of Ukraine. The article examines cluster statistics for individual EU countries. Gross Domestic Product Growth (Decrease) Rate for

\footnotetext{
${ }^{35}$ Соколенко C.I. Зазначена праця. - С. 344.
} 
the analyzed group of countries from 2008 to 2017. Cluster development achievements in Poland, Slovakia and Romania.

\section{REFERENCES}

1. Соколенко С.I. Кластери в глобальній економіці / С.I. Соколенко. - К.: Логос, 2004. - С. 181.

3. Зазначена праця. - С. 184, 185.

4. Чужиков B.I. Кластерна політика Свропейського Союзу / В.І. Чужиков, С.Д. Лук'яненко // Економіка України. - 2013. - № 2 (615). C. 81-91.

5. Чужиков B.I. Кластерна політика Європейського Союзу / В.І. Чужиков, С.Д. Лук'яненко // Економіка України. - 2013. - № 2 (615). C. 83; Портер М. Международная конкуренция / М Портер. - М.: Международные отношения, 1993. - 896 с.

6. Чужиков B.I. Кластерна політика Свропейського Союзу / В.І. Чужиков, С.Д. Лук'яненко // Економіка України. - 2013. - № 2 (615). C. 86 .

7. Марчук О.И. Кластерная стратегия инновационного развития экономик Беларуси и Украины / О.И. Марчук, Т.А. Яшева, Н.Т. Рудь / Проблеми інноваційного розвитку економіки України: Збірник наукових праць 3 актуальних проблем економічних наук // Наукова організація «Перспектива». У 2-х частинах. - Дніпропетровськ: Видавничий дім «Гельветика», 2014. - Ч.2. - 312 с.

8. Соколенко С.І. Кластери в глобальній економіці / С.І. Соколенко. - К.: Логос, 2004. - С. 207, 209.

9. Соколенко С.І. Кластери в глобальній економіці / С.І. Соколенко. - К.: Логос, 2004. - С. 470-472.

10. WEF Knowhenge Nawigator-Germany, 2003 // http:// www.wevorum.org.de

11. Гамор Федір. Всесвітнє визнання букових пралісів Карпат: історія та менеджмент / Матеріали 3 нагоди десятиріччя утворення об'єкта Всесвітньої спадщини ЮНЕСКО «Букові праліси Карпат та давні букові ліси Німеччини». - м. Ужгород, Вид-во «ФОП «Сабов А.М.». 2017. -248 c.

12. Гамор Федір. Всесвітнє визнання букових пралісів Карпат: історія та менеджмент / Матеріали 3 нагоди десятиріччя утворення об’єкта Всесвітньої спадщини ЮНЕСКО «Букові праліси Карпат та давні букові ліси Німеччини». - м. Ужгород, Вид-во «ФОП «Сабов А.М.». 2017. - C. 87.

13. Гамор Федір. Зазначена праця. - С. 105.

14. Гамор Федір. Зазначена праця. - С. 107. 
15. Гамор Федір. Зазначена праця. - С. 131-134.

16. Гамор Федір. Зазначена праця. - С. 131-132.

17. Екологія і закон. Екологічне законодавство України. У двох книгах. Книга 2; Відп. ред. акад. УЕАН В. І. Андрейцев. - К. : Юрінком Інтер. - 1997. $-574 \mathrm{c}$.

18. Гамор Федір. Зазначена праця. - С. 38.

19. Економічна енциклопедія: [у 3 т.]. - Київ: Видавничий центр «Академія», 2002. / Голова редакційної ради: Гаврилишин Б. Д. (голова) [та ін.]. Т. 1 / [відп. редактор Мочерний С. В. та ін.]. - 2002. - 864 с.

20. Екологічна енциклопедія: У 3 т. / Головн. ред. А. В. Толстоухов та ін. - К.: ТОВ «Центр екологічної освіти та інформації», 2007. - Т. 2: €-H. -416 c.

21. Соколенко С.I. Кластери в глобальній економіці / С.I. Соколенко. - К.: Логос, 2004. - С. 2.

22. Гамор Федір. Всесвітне визнання букових пралісів Карпат: історія та менеджмент / Матеріали 3 нагоди десятиріччя утворення об’єкта Всесвітньої спадщини ЮНЕСКО «Букові праліси Карпат та давні букові ліси Німеччини». - м. Ужгород, Вид-во «ФОП «Сабов А.М.». 2017. - C. 87.

23. Гамор Федір. Зазначена праця. - С. 41.

24. Гамор Федір. Зазначена праця. - С. 72, 73.

25. Гамор Федір. Зазначена праця. - С. 78.

26. Розміщення продуктивних сил: Підручник / В.В. Ковалевський, О.Л. Михалик, В.Ф. Семенова. - 3-тє вид., випр. і доп. - К.: ТОВ «Знання», КОО, 2001. - 353 с. - (Вища освіта XXI ст. ).

27. Статистичний щорічник України за 2012 рік / Державна служба статистики України. - Київ: ТОВ «Август-Трейд». - 2013. - С. 535, 536. Статистичний щорічник України за 2017 рік / Державна служба статистики України. - Київ: Державне підприємство «Інформаційноаналітичне агентство». - 2018. - С. 525, 526.

28. Соколенко С.І. Кластери в глобальній економіці / С.І. Соколенко. - К.: Логос, 2004. - С. 315.

29. Соколенко С.I. Зазначена праця. - С. 318, 319.

30. Соколенко С.I. Зазначена праця. - С. 322.

31. Соколенко С.I. Зазначена праця. - С. 318-319.

32. Соколенко С.I. Зазначена праця. - С. 302, 304, 308.

33. Україна в системі європейської інтеграції [текст]: Монографія. Навч. посібник / М. Палінчак, В. Приходько, В. Химинець та ін. Ужгород: ТОВ «РІК-У», 2016. - 344 с. 
34. Україна в системі європейської інтеграції [текст]: Монографія. Навч. посібник / М. Палінчак, В. Приходько, В. Химинець та ін. Ужгород: ТОВ «РІК-У», 2016. - С. 240, 241.

35. Соколенко С.І. Зазначена праця. - С. 338-340.

36. Соколенко С.I. Зазначена праця. - С. 344.

Information about the author:

Palinchak M. M.,

Doctor of Political Science, Professor,

Dean of the Faculty of International Economic Relations,

Uzhhorod National University

14, Universytetska str, Uzhhorod, 88000, Ukraine 


\section{ACTUAL DIRECTIONS OF STATE-OWNED ENTERPRISES COMPETITIVENESS ENSURING}

\section{Tsalan M. I.}

\section{INTRODUCTION}

Entrepreneurship and its development are at the heart of the economic system of countries, regardless of their development level, except the households that are in the early stages of economic development. Nowadays the entrepreneurship in Ukraine is developing, but its functioning is influenced by negative economic and political factors, which on the one hand significantly impedes its development, while overcoming this influence is a stimulating tool for improving the entrepreneurial environment.

\section{The role of state support in the development of Ukrainian entrepreneurship}

Primarily economic and political factors are the main factors that directly affect entrepreneurship in the country. Economic ones include inflationary fluctuations in the national economy, ineffective tax policies, long-lasting general economic instability in the country as a result of the global financial crisis, the Revolution of Dignity, hostilities in the East, corruption, etc. Political factors include political lobbying, the imperfection and often contradictions of the legislative framework, instability of the government and inefficiency of state policy. The problems that impede entrepreneurship are not only at the level of the country, region, or simply the environment in which business entities operate. Problems also occur at the enterprise level, namely: outdated material and technical base, low level of innovation, lack of skills, inconsistency in the position etc. In order to overcome them and successfully develop entrepreneurial activity in the state and regions, it is necessary to ensure an adequate level of state support, which according to G.M. Skudar should be shown in creating the necessary prerequisites for effective work of enterprises ${ }^{1}$. Relevant actions by the state are urgent: from financial to consulting assistance. In Ukraine, public enterprise policy should be oriented towards raising its role and place in the country's economic system. $\mathrm{N}$. Ignatovych and O. Vetchynov point out that the task of the state is to define

1 Скудар Г.М. Організаційно-економічний механізм управління конкурентоспроможністю підприємства: автореф. дис. ... д.е.н. : 08.02.03. Донецьк, 2000. 40 с. 
the institutional and legal framework of entrepreneurship, to create new regulatory mechanisms that complement the competitive market mechanism, preserving freedom of business activity with focus on satisfying public interests, while preserving the nature environment, aligning it with state priorities $^{2}$.

Within the framework of promoting entrepreneurial development, special attention should be paid to the field of state entrepreneurship. The stateowned entrepreneurship is often seen as the economic activity of state-owned enterprises that create tangible goods and provide the services necessary for the development of the national economy. L.Ye. Furdychko notes that providing the public with public goods is among the goals of state entrepreneurship. Unlike individual goods, the production of which is essentially the prerogative of private business, public goods are of the public interest ${ }^{3}$. State entrepreneurship is an instrument of the state economic policy realization, aimed at the development of the economic potential and the public goals achievement. According to G.Ya. Anilovskaya, social equilibrium achieving is an important factor in the development of state-owned entrepreneurship ${ }^{4}$ (Anilovskaya, 2007).

There are discussions in the scientific community about the feasibility of keeping state-owned enterprises in the future, but at the same time appropriate areas remain where they cannot be fully privatized because of the major state resource in the centre of the industry.

The dynamism of the processes that take place in the modern economy necessitates a rethinking of the different ownership enterprises activities basis. The principles of modern companies work are changing, new socio-economic and organizational-economic relations are emerging at the horizontal level ${ }^{5}$. New trends in the national and international economic environments place new requirements before enterprises of different ownership types, including stateowned ones, for reorientation of activities and a system of measures for timely adaptation to these changes. While private enterprises carry out these activities faster, focusing on their own vision, market research and their own capabilities,

${ }^{2}$ Ігнатович Н., Ветчинов О. Державне регулювання як фактор сучасного розвитку підприємництва: світовий досвід. Вісник Киїського національного університету. 2011. № 124. -125 . С. 52-54.

3 Фурдичко Л. Є. Державне підприємництво та його фінансування в Україні. Репозитарій Національного університету «Львівська політехніка». 2011. URL: http://ena.lp.edu.ua:8080/bitstream/ntb/16713/1/382-656-657.pdf

4 Аніловська Г. Я. Місце та роль державного підприємництва в ринковій трансформації. Науковий вісник Національного лісотехнічного університету України. 2007. URL: http://nltu.edu.ua/nv/Archive/2007/17_1/173_Anilowska_17_1.pdf.

${ }_{5}^{5}$ Кочубей Р.В. Содержание понятия «предпринимательская структура». Маркетинг $i$ менеджмент інноваиій. 2012. № 1. С. 64-68. 
state-owned enterprises are often forced to obey government regulation and expect state support.

State-owned enterprises are run by the public authorities, it creates a foundation for them to protect themselves against particular competitive threats and challenges, but at the same time, the lack of an adequate level of financial security does not reduce the risks and challenges of their operating conditions. It is necessary to note that individual steps have been taken in Ukraine, in particular the Strategy for Improving the Public Sector Economic Entities Activities Efficiency was adopted by the Cabinet of Ministers of Ukraine decree No. 662-r of May 27, 2015. This Strategy provides equal conditions in the market for state and private enterprises activity in order to create competitive conditions for them and to stimulate transparent and efficient work for a positive impact on the national and regional economy and the business environment as a whole.

Forestry is one of the important economic activity areas for Ukraine, namely:

- an important component of national and regional wealth;

- favorable ecological environment for human health and source of raw materials for economic development;

- by-products are valuable both for consumers and for production processes;

Forestry belongs to the primary sector of the economy, but at the same time it is closely linked to the secondary, tertiary and quaternary sectors. Forestry is closely interconnected with:

- industry (manufacture of furniture, medicines, perfumes, equipment etc.);

- construction (construction of buildings);

- wholesale and retail trade (sale of timber and by-products);

- agriculture (beekeeping, grazing);

- provision of services (financial, insurance, transport, educational etc.);

- information technologies (application of innovations in the field of forestry).

The foregoing linkages of forestry with the industries imply the interaction of the economic agents working there. At the same time, forestry is a supplier of raw materials for some industries and a consumer of goods and services produced by others. Forestry activities are mainly carried out by forestry enterprises, which, by virtue of their state ownership and history of development in Ukraine, are characterized by:- low level of development and state support;

- activity in the conditions of economic crisis;

- lack of effective organizational and economic support for their development; 
- outdated principles of conducting business activities that do not take into account the factors of competition and their full participation in market relations.

To ensure the competitive development of forestry in the future, E.M. Libanova's view is important. She believes the forestry sector of Ukraine needs immediate organizational and economic transformations in order to ensure the self-sustainability of the industry, taking into account the interests of territorial communities in the context of modern development of the country ${ }^{6}$.

Forestry activity improvement in the regions of Ukraine should be carried out in a comprehensive and simultaneous way with the reform of the entrepreneurial environment in general, the state enterprise sector in particular, otherwise all measures will be ineffective. It is difficult for forestry to overcome the challenges they face in their activities, only with the help of micro- or mezzanine level tools. Being state-owned, without state funding, they are forced to carry out economic activities in the sphere of risk and to manage the results to ensure forestry activities.

For the future development of forestry activity in the conditions of competition, it is important to coordinate the interaction of components of the organizational and economic mechanism, namely the subjects of implementation and regulation of forestry activity in the region, using the appropriate set of tools and levers.

We believe that the aim of the organizational and economic mechanism of forestry activity development in the region should be - to ensure its competitive development in the region, and the mechanism should be based on a system of principles, which must include:

- continuity of development - work on improving forest management must be continuous;

- systematic - the development of forestry activities is an integral part of the ecological, economic and social system and therefore all steps of development must take into account environmental, economic, social interests and tasks;

- principle of continuous monitoring - provides timely analysis of current forestry activities and taking appropriate measures to correct the situation as needed;

- purposefulness - the application of the mechanism is oriented towards the achievement of the main goal of the regional forestry activity;

${ }^{6}$ Соціально-економічний потенціал сталого розвитку України та ії регіонів / за ред. Е.М. Лібанової, М.А. Хвесик. Київ : ДУ ІЕПСР НАН України, 2014. 775 с. 
- controllability - the use of appropriate levers and tools makes it possible to control the current state of the forest industry in the region, to control the process of its development;

- adaptability - the mechanism should facilitate the development of forestry activities in the conditions of rapid change of their functioning environment;

- constructiveness - organizational and economic mechanism provides strategic orientations for perspective development of forestry activities, means of their achievement to ensure the stability of the system.

\section{Foreign experience of competitive development models}

In order to ensure competitive development, forest managers often seek appropriate solutions in managing the enterprise and take into account the conditions of the region and the state development. For qualitative changes in forestry, the positive experience of foreign experience should be taken into account. Considering the need to increase the attention of forestry enterprises to competitiveness issues, it is first of all advisable to study foreign experience of improving the enterprises competitiveness and to borrow acceptable elements. As B.M. Kurganska rightly points out, in the current conditions enterprises seek ways to survive in a difficult market environment. Due to this, the problem of enterprises competitiveness ensuring and the use of foreign experience on this issue becomes even more important and relevant ${ }^{7}$.

As the problems in the area of forestry personnel in the regions and the fluidity of employees exist, it is advisable to consider the Japanese experience of the competitive position of the enterprise enhancing, based on human factors, diligence of employees of the enterprise and Japanese philosophy. The advantages of the Japanese approach (according to Dr. Furuya Noriya) include a strong sense of belonging to the organization (life-long hiring), a high level of cooperation between employees, a high adaptive potential to a high level of customer requirements, a high level of involvement in work, flexible attitude to work, continuous improvement ${ }^{8}$. In order to implement such an approach in Ukraine and in the regions, there should be motivation (including financial one) for people to work diligently at state-owned enterprises for a long time.

Kaizen's philosophy is important at Japanese enterprises, which envisages continuous improvement for both executives and ordinary employees. Kaizen is a Japanese term meaning "continuous improvement", or "change for

${ }^{7}$ Курганська Б. М. Організаційно-економічні механізми забезпечення конкурентоздатності підприємства (на прикладі швейної промисловості) : дис. ... канд. екон. наук : 08.06.01. Львів, 2002.

${ }^{8}$ Празян М. Фактори підвищення конкурентоспроможності в управлінні виробництвом. Японський досвід. Вісник Київського національного університету. 2011. № 124- 125. С. 46 - 49. 
the better". It is a Japanese philosophy based on the continuous improvement of processes in production, management and business as a whole. Its main components are cost reduction, continuous improvement of work efficiency, rational organization of workplaces, quality control, standardization. This philosophy is based on the principles of teamwork, particularly in small groups, motivation of employees to participate in the development of new ideas, stimulation of creative interest, education of personal discipline.

Kaizen's advantage and difference from western concepts is that it supports continuous improvement of processes, often in small steps, without the need for financial costs, while western countries base the competitive development of the enterprise on the introduction of innovations, i.e. technological improvements, which are more difficult to implement in modern times. The Japanese view is convincing that money infusion into a business will not give effect, if business processes are not optimal ${ }^{8}$.

In the regions of Ukraine, especially at state-owned enterprises, including forestry ones, almost no attention is paid to optimizing activities by constantly improving the organization of staff work, including through motivation for professional growth. In Ukraine, the basis of legal entrepreneurship, effective management, which takes into account the trends, needs and requirements of the modern market, should come to the realization. It is important to remember that in the globalized world, in a context of powerful information support and European integration, it is more profitable to build a business system transparently.

The US model of competitive enterprise development is based on the creation and use of a number of specialized strategic programs to improve the competitiveness of the final product. They are based on the understanding of the importance of the such a program implementation, the development of motivational factors for the production of competitive products and quality control system, minimizing defects in work, cost estimation for improving competitiveness. The control system is important. The main criterion for the effectiveness of the product competitiveness management system in the United States is the degree of satisfaction of customer requests ${ }^{9}$.

Drawing parallels with doing business in Ukrainian realities, it should be noted that in Ukraine insufficient attention is paid to the development of an effective system of incentives for workers and the organization of defect-free work, especially at state-owned enterprises. It is important to keep in mind that the professionalism of the internal work organization at the enterprise should

${ }^{9}$ Дахно, I.І., Бабіч, Г.В., Барановська В.М. та ін. Зовнішньоекономічний менеджмент: Київ: Центр учбової літератури. 2012 URL: http://shron.chtyvo.org.ua/Dakhno_Ivan/ Zovnishnoekonomichnyi_menedzhment.pdf 
increase, especially if the success of the enterprise depends on it, under any circumstances.

The Western European experience of competitiveness ensuring envisages its provision and enhancement at the design stage of activity. The possibility of errors and deviations is minimized when designing a product. This principle in Europe is called "defining errors, causes and remedies analyzing". The cost of eliminating the error is greater when it is determined later. Western European corporations grant the consumer the right to make their claims regarding the competitive parameters of the products used. This encourages firms to improve their production ${ }^{9}$. In European business practice, the concept of multi-sector is widely used to enhance the competitive position of the enterprise, enhance its activity, increase profits through the related services production, and therefore the formation of additional areas minimize risks in the event of the main activity failure.

Based on the analysis of the enterprises competitiveness ensuring experience, it should be noted that its elements are common and therefore can also be applied in the field of forestry at the regional level. Today, the lack of competition in the traditional sense between state forestry enterprises is often one of the reasons for the lack of motivation of the managers to improve their competitive position constantly. The demand for development actualises this issue. The aim to become better, to compete for the improvement of its competitive positions should be at the heart of the economic activity of forestry enterprises and therefore it is best to apply a mixed approach that combines elements of different enterprise competitiveness achieving approaches.

Measures that should be kept in mind by managers in forest industry in order to ensure the competitive enterprise development are the following:

- permanent improvement of activity;

- program approach to development;

- pre-project analysis;

- orientation of development to market needs;

- motivational mechanisms;- defect minimization and control.

Managers in forest industry and in other spheres, should become managers with a new type of thinking about enterprise management and profit, change outdated inefficient management approaches, and actively apply an incentive mechanism to maximize results.

Experience should be gained not only in the organization of internal work of the enterprise, but also in the field of efficient forestry activities. This process has already been partially implemented, in particular the experience of Switzerland, a country where forestry is at a high level. Although the system of ownership and history of the Carpathian and Swiss forests are significantly different, but the natural conditions are close, which allows the Swiss forestry 
methods introduction into the Ukrainian forests, in particular the forests of Transcarpathia. Within the framework of the Agency for Sustainable Development of the Carpathian region "Forza", projects of cooperation between Switzerland and Ukraine are being implemented in the area of close to nature forestry. In Switzerland, it is used in $90 \%$ of the forest area. According to this approach stable, multi-breed, stands are being grown, using selective rather than continuous felling. This approach saves financial resources on reforestation and felling through the use of nature-friendly logging technologies.

In Switzerland's forestry practice, community involvement in forest management is worth of consideration. Most forests are community-owned and forest managers only help to manage them. their activities are largely dependent on community taxes, so they have to prove the effectiveness of their actions in forestry ${ }^{10}$.

The issue of forest ownership changes in Ukraine and the regions is debatable. On the one hand, researchers point out that private ownership can stimulate more efficient forest management, while others consider it as a challenge to transfer forests in Transcarpathia and Ukraine as a whole to other forms of ownership. The distribution of economic and controlling functions may be threatened and the State Forestry Agency will lose control over the activities of forestry enterprises. It may happen that the state will perform economic functions for forest protection and reforestation, and private structures - logging, which is attractive from a commercial point of view. Of course, this issue needs in-depth analysis, but first the economy needs to go through a stage of cleaning up corruption schemes, get out of the shadows and change the mentality of people and their attitude to the forest, changing it from a grueling exploitative to a weakly lean one. In the regions of Ukraine, the territorial community often stands aside from forestry, not always having the will and right to intervene, with the exception of individual civic activists. The tools of their influence are the possibility of appeals to check the legality of actions in the forest area and fixation of forest disturbances. For the development of forestry in the region, a harmonious coexistence of forest areas and people should be ensured, without uncontrolled deforestation, which is immediately reflected in their living conditions. Within the framework of the project of introducing nature-friendly forestry, methods of involving communities in forest management planning were tested. But experts from the Forza project noted that neither the authorities nor the communities themselves are fully prepared for active cooperation in forest management. Indeed, in Ukraine, the population is mostly inert to the problems of the forest, people are

${ }^{10}$ Представники міжурядового проекту FORZA вважають, що Закарпаття не готове до залучення сільських громад до ведення лісового господарства. URL: http://zik.ua/ua/ news/2005/09/16/19312. 
busy solving their own more urgent problems. This issue should be addressed through the educational component - the person first must protect the environment in which he/she lives and be interested in using resources effectively. In foreign countries, young people are widely involved in the conservation of the forest fund and in the awareness of its environmental and economic importance. In particular, in Hungary there is a forest information center, where you can get information about the forest.

Analyzing the experience of Sweden, we can identify the following key points that should be addressed in the forestry of Ukraine, namely:

- the law on forestry adopted in Sweden in 1903 has for a long time been at the heart of the Swedish model of forest management, based on the cultivation of one-year stands and the predominance of logging. Due to the fact that this law ceased to be in line with the new vision of future forestry development, in 1993 a new law on forestry was adopted, which took into account changes in the country's forestry policy, namely the emphasis on biodiversity and forest legislation. The priorities were the integration of an approach to environmental protection and the production of quality wood (ecological and economic function) with a predominant selective type of felling. In other words, forest policy, if inconsistent with the realities of the present, can and should be changed, but at the same time should be thoughtful, consistent, and take into account the requirements of the present;

- there is an active cooperation of various branches of government with forestry institutions in Sweden;

- the use of modern equipment in the work of forestry enterprises. Wood is cut according to its quality and plans for further processing using computer technology. X-ray scanners and tomographs are widely used to determine the quality of wood. Much has to be done in Ukraine. The innovation and technological update, as already mentioned, is at a low level, which hinders the development of forestry activities on the basis of competitiveness. An important step forward would be the widespread adoption of drones in the work of foresters for inspection of large areas, monitoring of damaged timber, which would save time and costs for forest area research;

- effectively established cooperative links between forestry and logging enterprises. Much of the physical labor is freed and refocused on controlling and managerial functions. In Sweden, the work of robots has been used in the forestry process for a long time;

- optimized processes of use of wood and waste after its processing. To heat the living quarters, the bark is burned after the process of frying;

- forest policy in Sweden is based on freedom and responsibility, the value of forests is increasing in the long run, and a long-term forest management plan (approximately 20 years) is being developed accordingly; 
- forest ownership in Sweden is divided between individuals (50\%) and companies $(25 \%)$, the state and the church $(25 \%)$, but this does not affect the efficiency of forestry management, as forest law is one for all;

- balance between rational forest management (timber harvesting and processing as an economic function) and conservation of forest resources (in terms of environmental function) ${ }^{11}$.

Having analyzed the experience of Poland, we believe that some elements may be useful for application in Ukraine, in particular, the burden of taxation. The basis of taxation is the area of forest in use, which is an incentive to improve the efficiency of forestry and harvest the maximum volume of timber. In this case, the sense of concealing the results of entrepreneurial activity is lost. As the forest tax in Poland is local, the state thus supports the forest community and promotes efficient forest management.

The experience of Germany is interesting in terms of forestry management. Forest and timber play an important role in the structure of the German economy, with 1.2 million jobs and an annual turnover of 170 billion euros. In Germany, the concept of "efficient and economical" forestry has justified itself. Nowadays, forest in Germany is used as a source of timber, with particular attention being paid to its origin from ecological territory. In Germany, a high-level certification system is developed. The presence of the certificate is a proof of the environmental conditions of the wood origin. Germany states that all timber used by state-owned enterprises must come from eco-friendly territories, from forests that have PEFC (The Programme for the Endorsement of Forest Certification) or FSC (Forest Stewartship Council) certification. An element of German forestry experience is the use of GPS satellite navigation, which enables quick orientation and accurate finding of harvested timber in the forest. With the help of modern computer software, it is possible to monitor the state of forest resources. In their work, forestry workers make extensive use of mobile stations to store information about the species composition of a particular forest area, the volumes and types of logging, and so on.

Summarizing the foreign experience of forestry management, the subjects of forestry activity in Ukraine should take into account:

- orientation towards nature-close forestry;

- compliance of forest management measures with modern tendencies of forestry development in terms of balance of ecological-economic function and social progress;- strengthening of interaction between foresters, authorities and community, involvement of young people in improving forestry, strengthening information, communication and educational functions of management;

11 Швецька модель лісоуправління. URL: https://www.youtube.com/watch?v= 
- long-term planning of forestry activities and efficiency of its organization in terms of innovative technical and technological support.

Considering the potential use of wood (as raw material) in national energy, medicine, production of construction materials, toys, etc., some efforts should be directed to the development of forestry with by-products, which requires its processing in the region, has economic and social impact. The processing of by-products in the region can be carried out independently by individual enterprises, in another way the creation of cluster structures is possible, which combine wood and by-products processing.

An important component of improving the organizational and economic mechanism for the development of forestry in the region is the approximation of the local population to the issues of forestry development.

In this case, it should be ensured:

- regularly informing the local population about the results of forestry management through online resources. Residents of the region should see the results of efficient management, the volume of harvesting and reforestation work, the amount of payments to the budget, the profits and investments in forestry, as well as the problems in the region in this area, measures taken to solve them. This will increase public confidence in the industry and the effectiveness of their management practices;

- joint activities of local people, representatives of forestry and regional authorities on clearing individual forest areas;

- participation of competent citizens in decision-making in the forestry sector, which will facilitate the transparency of the process and make it impossible to approve inefficient decisions;

- to implement on a proper basis public control over forest management;

- to step up youth education and awareness-raising activities regarding the caring of the forest as a place for recreation and leisure. To this end, we support the initiative to promote school forestry, joint actions of forestry workers with schoolchildren to plant forests.

For competitively oriented forestry enterprises, an appropriate infrastructure should exist in the regions, i.e a system of state and nongovernmental structures that will facilitate the rapid adaptation of forestry entities to competitive market conditions. Such infrastructure should address the lack of relevant knowledge, skills and experience of competitiveness. These can be support funds, information and consulting centers, consulting firms. Lack of information on new developments in the field of forestry can be solved by stimulating the exchange of experience between business leaders, lower-level employees, publishing articles, round tables holding, thematic seminars etc.

In order to achieve forestry enterprises competitiveness, state aid is needed as one of the tools for stimulating economic activity in order to achieve 
economic, social and political goals in the domestic and foreign markets ${ }^{12}$. State aid should motivate business entities to work effectively for profit. State aid can be manifested in the form of tax benefits, compensation from state aid providers, which may be central and local executive authorities, local governments.

It is important to introduce a market-based forestry management system in accordance with the declared decentralization trends. The issue of a clear division of forest management is discussed. Today, it is advisable to expand the powers of regional authorities in regulating and facilitating forestry in the region, particularly in the forestry enterprises financing. But, in addition to the positive effects of the reallocation of powers, decentralization reform contains challenges at the initial stage of its implementation, namely:

- the need for legislative consolidation of the powers of the united territorial communities for decision-making in the field of forestry;

- gaining relevant experience;

- search for ways of financial and material support of forestry needs;

- mechanisms for exercising this kind of authority.

The focus of management shifting to the regional level in combination with other measures to improve forestry would increase interest in its effectiveness. In order to intensify the cooperation of forestry entities with local executive authorities, local self-government bodies, it is necessary to hold frequent meetings to discuss urgent problems and issues of further development.

The creation of a forestry cluster and expansion of program approaches to development that take into account regional peculiarities and needs is particularly important direction of activation of the forestry activity development mechanism in the region.

\section{CONCLUSIONS}

In Ukraine, the development of forestry activities should be carried out in the context of effective reforms of the business sector as a whole and of stateowned enterprises in particular, since only in a stable and economic environment created by the state the effectiveness of the implemented measures can be expected.

In order to ensure the development of forestry activities with the aim to achieve a higher level of competitiveness, forestry activities should be undertaken both at the enterprise level and at the regional level. To achieve the same goal, it is advisable to borrow elements of foreign experience. To ensure

${ }^{12}$ Концепція реформування системи державної допомоги суб'єктам господарювання. Схвалено розпорядженням Кабінету Міністрів України від 13 січня 2010 р. № 81-p. URL: http://zakon.nau.ua/doc/?uid=1095.5925.0 
the competitiveness of forestry enterprises, it is necessary to consolidate the focus on continuous improvement of their activities, program development approach, application of pre-project analysis and consideration of market requirements, apply motivational mechanisms in work, focus on minimization of defects and activation of control measures. Considering the foreign experience in forest management, it is necessary to take into account the compliance of forest management measures with the modern requirements of forestry development, taking into account ecological and economic equilibrium and social development goals, orientation to nature-friendly forestry, mutual approximation of forest authorities, community authorities, orientation on innovation and technological renewal of forestry.

\section{SUMMARY}

The role of state support in the development of entrepreneurship in Ukraine has been analyzed by the author. The state-owned entrepreneurship is a tool for the implementation of state economic policy, strengthens its economic potential and contributes to the fulfillment of social goals and their achievement. The individual state-owned enterprises are strategically important for the future development of the state and their transformation into private property can pose a threat to the economic security of the country. The need to implement the foundations of competitive development in such enterprises has also been considered by the author. The foreign experience of enterprises competitiveness improving and the possibility of its use in Ukraine have been considered. Applying the elements of foreign experience can be successful along with activities undertaken by businesses, authorities, relevant management institutions and the local community. The creation of cluster structures is one of the promising directions of increasing the competitiveness of state-owned enterprises.

\section{REFERENCES}

1. Скудар Г.М. Організаційно-економічний механізм управління конкурентоспроможністю підприємства: автореф. дис. ... д.е.н. : 08.02.03. Донецьк, 2000. 40 с.

2. Ігнатович Н., Ветчинов О. Державне регулювання як фактор сучасного розвитку підприємництва: світовий досвід. Вісник Київського національного університету. 2011. № 124. -125. С. 52 - 54.

3. Фурдичко Л. Є. Державне підприємництво та його фінансування в Україні. Репозитарій Національного університету «Львівська політехніка». 2011. URL: http://ena.lp.edu.ua:8080/bitstream/ntb/16713/1/ 382-656-657.pdf. 
4. Аніловська Г. Я. Місце та роль державного підприємництва в ринковій трансформації. Науковий вісник Національного лісотехнічного університету України. 2007. URL: http://nltu.edu.ua/nv/Archive/2007/17_1/ 173_Anilowska_17_1.pdf.

5. Кочубей Р.В. Содержание понятия «предпринимательская структура». Маркетинг і менеджмент інноващій. 2012. № 1. С. 64-68.

6. Соціально-економічний потенціал сталого розвитку України та їі регіонів / за ред. Е.М. Лібанової, М.А. Хвесик. Київ : ДУ ІЕПСР НАН України, 2014. $775 \mathrm{c.}$

7. Курганська Б. М. Організаційно-економічні механізми забезпечення конкурентоздатності підприємства (на прикладі швейної промисловості) : дис. ... канд. екон. наук : 08.06.01. Львів, 2002.

8. Празян М. Фактори підвищення конкурентоспроможності в управлінні виробництвом. Японський досвід. Вісник Київського нащіонального університету. 2011. № 124-125. С. 46-49.

9. Дахно, I.I., Бабіч, Г.В., Барановська В.М. та ін. Зовнішньоекономічний менеджмент: Київ: Центр учбової літератури. 2012 URL: http://shron.chtyvo.org.ua/Dakhno_Ivan/Zovnishnoekonomichnyi_menedzhment.pdf

10. Представники міжурядового проекту FORZA вважають, що Закарпаття не готове до залучення сільських громад до ведення лісового господарства. URL: http://zik.ua/ua/news/2005/09/16/19312.

11. Швецька модель лісоуправління. URL: https://www.youtube.com/ watch? $\mathrm{v}=\mathrm{d} 0 \mathrm{HwOAcjcQE}$.

12. Концепція реформування системи державної допомоги суб'єктам господарювання. Схвалено розпорядженням Кабінету Міністрів України від 13 січня 2010 р. № 81-p. URL: http://zakon.nau.ua/doc/ ?uid=1095.5925.0

\section{Information about the author:} Tsalan M. I., Candidate of Economic Sciences, Associate Professor, Uzhhorod National University 14, Universytetska str, Uzhhorod, 88000, Ukraine 


\title{
POLITICAL DISCOURSE IN A TRANSITIONAL SOCIETY: BETWEEN THE SCYLLA OF ANARCHY AND THE CHARYBDIS OF TYRANNY
}

\author{
Yakovlev D. V., Yeremenko O. M.
}

Politicians in our times feed their clichés to television, where even those who wish to disagree repeat them... Everything happens fast, but nothing actually happens. Each story on televised news is "breaking" until it is displaced by the next one.

So we are hit by wave upon wave but never see the ocean

Timothy Snyder "On Tyranny: Twenty Lessons from the Twentieth Century"

\section{INTRODUCTION}

The role of discourse grows during major political changes. It is becoming one of the most important political resources used in the struggle for power in a transitional society. Discourse is at the same time an effective tool for protecting interests (whatever or whomever they may be) and the ground of the collision of information messages of different genres and orientation in the process of competition for domination in the public opinion.

Discourse presents current political and social practices (Fairclough, N. $(2000)^{1}$, Wodak, R., \& Meyer, M. $\left.(2001)^{2}\right)$, expresses social identities, political ideology, and culture. Even the very definition of the political culture in the modern world contains an inclusion in the discourse: “... we can define political culture as the aggregate of political ideas, knowledge, traditions and values ... which defines the political process and which is expressed through political discourse" (Ordukhanyan E. (2019)) .

Discourse is an important element in the analysis and construction of the relations of power: "Discourse forms and represents public opinion, mass representations, stereotypes, beliefs and prejudices. The anthropological

${ }^{1}$ Fairclough, N. (2000). Discourse, social theory, and social research: The discourse of welfare reform. Journal of Sociolinguistics, 4, pp.163-195. Doi: 10.1111 / 1467-9481.00110

${ }^{2}$ Wodak, R., \& Meyer, M. (2001). Critical discourse analysis: History, agenda, theory and methodology, In R. Wodak \& M. Meyer (Eds.), CDA Methods). London: Sage. pp. 2-21.

${ }^{3}$ Ordukhanyan, E. (2019). A comparative analysis of theoretical and methodological foundations of political culture. Wisdom, (1 (12)), 38-48. 
dimension of politics allows us to imagine the space of power struggles as a network of different discourses, visions of the past, present and future of man, power and society. After all, discourse always places particular importance on those political practices that take place at the level of an individual politician or social group. The discourse reflects and at the same time limits the social, epistemological and rhetorical practices of the group" (Eremenko A., Yakovlev D. (2019) $)^{4}$.

Discourse means that “... social properties or relations of, e.g, class, gender or ethnicity, are thus systematically associated with the structural units, levels, or strategies of talk and text embedded in their social, political and cultural contexts. The same is true of relations between social organizations, institutions, groups, roles, situations, power, or political decision making, on the one hand, and discourse structures, on the other hand ... In relationships of dominance, such ideological discourse may thus Serving to sustain or challenge social positions" (Van Dijk, T.A. (2006) $)^{5}$.

The latter is a crucial feature of the political discourse of a transitional society. The use of Critical Discourse Analysis allows revealing “... authentic everyday communication in institutional, media, political or other locations rather than sample sentences or sample texts constructed in linguists' minds" (it is noteworthy that it concerns the minds of political scientists and sociologists - D.Y., O.Y.) (Wodak, R., \& De Cillia, (2009)) ${ }^{6}$.

Researching the political discourse as a form of social practice allows noticing "...a dialectical relationship between particular discursive acts and the situations, institutions and social structures in which they are embedded: the situational, institutional and social contexts shape and affect discourse, and, in turn, discourses influence social and political reality. In other words, discourse constitutes social practice and is at the same time constituted by it. Through discourses, social actors constitute objects of knowledge, situations and social roles as well as identities and interpersonal relations between different social groups and those who interact with them. Furthermore, discursive acts are socially constitutive in a variety of ways. Firstly, they are largely responsible for the genesis, production and construction of particular social conditions.

${ }^{4}$ Eremenko A., Yakovlev D. (2019). "My dialektiku uchili ne po Gegelyu". Filosofiya v zerkale politicheskoy propagandy: popytka antropologicheskogo podkhoda ["We studied dialectics not according to Hegel". The philosophy in the mirror of political propaganda: an attempt to the anthropological approach] Current problems of philosophy and sociology, no. 24, pp. 10-23. https://doi.org/10.32837/apfs.v0i24.885

${ }^{5}$ Van Dijk, T.A. (2006). Ideological discourse analysis. Journal of Political Ideologies, 11(2), pp.115-140. DOI: 10.1080/13569310600687908

${ }^{6}$ Wodak, R., De Cillia, R., Reisigl, M., Liebhart, K., Hirsch, A., Mitten, R., \& Unger, J. (2009). The Discursive Construction of National Identity (2nd ed.). Edinburgh: Edinburgh University, $288 \mathrm{p}$. 
Secondly, they can contribute to the restoration, legitimation or relativisation of a social status quo (ante). Thirdly, discursive acts are employed to maintain and reproduce the status quo. Fourthly, the discursive practice may be effective in transforming, dismantling or even destroying the status quo (Wodak, R., \& De Cillia, (2009)) $)^{7}$.

The political discourse of a transitional society includes the use of the language of another one (in this case, the discourse of democratic countries) to describe and analyse its reality. The political discourse of a transitional society is often unable to "see" its own political reality without borrowing names, cliches, symbolic markers from other discourses. Because of this, it accepts the challenges of 1) anarchy and 2) returning to authoritarianism. In addition, the political discourse of the transitional society, most importantly for us, becomes the source of information about the desired social order. It becomes the practice of constructing the future.

This article offers an understanding of the political discourse in a transitional society. In Ukraine, the political discourse is being constructed as a clash of different "pictures of the world", remnants of Soviet clichés, linguistic and rhetorical borrowings from the discourse of democratic and capitalist countries. The political discourse is said to be uncivil. It is dominated by the influence of oligarchic groups that own media in Ukraine. Instead, civil society discourse is poorly represented. For a successful transition from authoritarianism to democracy and overcoming the challenges of anarchy in a "divided" Ukrainian society, it is necessary to demonstrate deep interaction between civil society discourse and political discourse, and to limit the influence of propaganda discourse.

\section{Uncivil Discourse in Ukraine. Limited Influence of Civil Society on Political Discourse}

In the age of transformations, discourse is a practical construction of visions of proper social order and political order that have yet to be built. The dialectical connection between discourse as a means of reflecting political and economic practices (Soviet, post-Soviet, etc.) and discourse as a reflection of the proper (in a sense true and desirable) is most clearly manifested in transitional societies. This is the essence of political transition. Discourse is not only a tool with the help of which they fight for the "right" picture of the world, the domination of public opinion by creating an attractive image of the future. It is the subject of political struggle, manipulation, and illusion in the era of "post-truth".

${ }^{7}$ Wodak, R., De Cillia, R., Reisigl, M., Liebhart, K., Hirsch, A., Mitten, R., \& Unger, J. (2009). The Discursive Construction of National Identity (2nd ed.). Edinburgh: Edinburgh University, $288 \mathrm{p}$. 
Ukrainian society is constantly discussing examples of political and economic practices, law and social behaviour in democratic societies that are broadcast by media discourse. Discourse not only reflects existing political practices. In a transitional society, the need to choose the purpose of the country's development ("democracy", "rule of law", "capitalism", "liberalism", "e-democracy", "resilience", "sustainability" etc.) is publicly declared and substantiated. Discourse becomes a "field of battle" of ideologies that are not represented in political activity. It promotes their legitimation, recognition by public opinion. This applies not only to ex-communist countries but also to EU countries that accept the challenges of integration and disintegration... study focuses on how European integration is debated in mass media, and how this affects democratic inclusiveness. Advancing integration implies a shift in power between governments, parliaments, and civil society. Behind debates over Europe's 'democratic deficit' is a deeper concern: whether democratic politics can perform effectively under conditions of Europeanization and globalization. It is... study on the Europeanization of media discourse and political contention to date, and a must-read for anyone interested in how European integration changes democratic politics and why European integration has become increasingly contested" (Koopmans, R., \& Statham, P. (2010)) ${ }^{8}$.

For over thirty years, transitional societies in Eastern Europe have been moving from Soviet socialism and authoritarian politics to capitalism and consolidated democracy. At the same time, they are included in global transformations related to the information society.

To a full extent, this applies to Ukraine, which, having fixed the regime of electoral democracy, occasionally experiences authoritarian spasms and overcomes them in the wake of the revolutionary waves of 2004 and 2013 2014. During the revolutions, the "eternal" question of political science "Who governs?" (Dahl, R. A. $(2005)^{9}$, Holland, H. M. (1963) $)^{10}$, and the winner of the presidential elections is trying to restore the authoritarian regime, even if it is called competitive authoritarianism (Way L. A. (2004)) ${ }^{11}$.

${ }^{8}$ Koopmans, R., \& Statham, P. (Eds.) (2010). The Making of a European Public Sphere. Media Discourse and Political Contention. Communication, Society and Politics. Cambridge: Cambridge University Press, 335 p. doi:10.1017/CBO9780511761010

${ }^{9}$ Dahl, R. A. (2005). Who Governs? Democracy and Power in an American City (2nd ed.). New Haven and London: Yale University Press, 355 p.

${ }^{10}$ Holland, H. M. (1963) Who governs? democracy and power in an american city By Robert A. Dahl 355 pp. New Haven and London: Yale University Press, 1961. Social Forces, vol. 41, pp. 322-323. Retrieved from: https://doi.org/10.2307/2573188

${ }_{11}$ Way, L. A. (2004). The Sources and Dynamics of Competitive Authoritarianism in Ukraine. Journal of Communist Studies and Transition Politics, 20:1, pp. 143-161. DOI:10.1080/ 13523270410001687145 
One of the major problems associated with researching the political discourse of a transitional society is determining the nature of transition, its ultimate purpose and intermediate stages. The situation is complicated by the presence of many competing visions of transition, from both internal and external players (actors). Even civil society, which is one of the main agents of transition, does not have a unified vision. "When civil society makes a 'transition' its label, it cannot be assumed that different civil society actors share compatible varieties of localist or radical transformationists discourses" (Feola, G., Jaworska, S. (2019)) $)^{12}$. The political discourse of a transitional society "... also contribute to shaping social imagination, motivations, and the debate around development, sustainability and society's future..." (Feola, G., Jaworska, S. (2019)) $)^{13}$.

In a transitional society, in the process of a struggle for power, organizational and institutional entities use a wide variety of resources. There are no restrictions here in the form of the institutions of consolidated democracy and the rule of law. In the political discourse of a transitional society, "archaic" meanings and symbols, myths of traditional societies, modern political ideologies, media technologies and postmodern practices intersect. This applies not only to discursive practices. The use of violence and economic pressure are becoming strategies of power. The political discourse is widely used to manipulate culture and religion, language and history. At the same time, one cannot underestimate the role of rationality in the construction of political discourse. Rationality in decision making and public policy, which peaked in the age of modernization, is a powerful accelerator of democratic transition. Even in ancient polises, the benefits of smart policy were realised, "Pericles of Athens was called not only "the first citizen", but also "a rational person" (Yakovlev, D.V. (2012)) $)^{14}$, "rationality is one of the fundamental foundations of the Modern Era, a democratic political institution. Without rationalization, it is impossible to imagine the processes of secularization (according to M. Weber "dissipation" of the political field), liberalization of economic, political, media spaces, pluralization, formation and development of the rule of law and civil

${ }^{12}$ Feola, G., Jaworska, S. (2019) One transition, many transitions? A corpus-based study of societal sustainability transition discourses in four civil society's proposals. Sustainability Science, 14, pp. 1643-1656. DOI https://doi.org/10.1007/s11625-018-0631-9

${ }^{13}$ Feola, G., Jaworska, S. (2019) One transition, many transitions? A corpus-based study of societal sustainability transition discourses in four civil society's proposals. Sustainability Science, 14, pp. 1643-1656. DOI https://doi.org/10.1007/s11625-018-0631-9

${ }^{14}$ Yakovlev, D.V. (2012) Mystectvo polityky z tochky zoru teoriji racionaljnogho vyboru [Art of politics in terms of the theory of rational choice] Proceedings of the Legal life of modern Ukraine: Mater., International Scientific Conf. Prof. Off-staff (Ukraine, Odesa, April 20-21, 2012) (ed. V.M. Dremin), Odessa: Phoenix, Vol. 1, pp. 211-213. 
society, professional management (bureaucracy), public policy, science and education, technological progress" (Yakovlev, D.V. (2014)) ${ }^{15}$.

The political discourse in a transitional society plays a very important role: "discourse is not just a referential tool that describes the social world; it is a symbolic means that constructs social realities through processes of naming, describing, informing, in short, through giving meaning to objects, situations and people. Language is the building block of discourse and the choice of language acts as a lens through which people, objects and situations are constructed. This lens will foreground certain features while marginalising others" (Feola, G., Jaworska, S. (2019)) ${ }^{16}$.

It must be free, rational and open to ensure the success of the transition. In order to build democracy in society, firstly, it must be constructed in the discourse. Does the political discourse in Ukraine meet these criteria? Obviously, it is more manipulative, reflecting the conflict of the owners of the media, oligarchs and bureaucracy (nomenclature) rather than the interests of large social groups. The former ones have a monopoly on the right to vote, forming the discourse by following selfish and narrow-minded interests. Oligarchic groups use symbolic capital to control the construction of discourse for the sake of domination in economics and politics.

The period of transition has become so long that it is suggested to abandon the term "transition": "The post-Cold War world has been marked by the proliferation of hybrid political regimes. In different ways, and to varying degrees, polities across much of Africa (Ghana, Kenya, Mozambique, Zambia, Zimbabwe), postcommunist Eurasia (Albania, Croatia, Russia, Serbia, Ukraine), Asia (Malaysia, Taiwan), and Latin America (Haiti, Mexico, Paraguay, Peru) combined democratic rules with authoritarian governance during the 1990s. Scholars often treated these regimes as incomplete or transitional forms of democracy. Yet in many cases these expectations (or hopes) proved overly optimistic. Particularly in Africa and the former Soviet Union, many regimes have either remained hybrid or moved in an authoritarian direction. It may therefore be time to stop thinking of these cases in terms of transitions to democracy and to begin thinking about the specific types of regimes they actually are" (Way, L. A. (2004)) ${ }^{17}$. Instead, "transition" remains a

15 Yakovlev, D.V. (2014) Pidkhid racionaljnogho vyboru v doslidzhenni mizhnarodnykh vidnosyn [Rational choice approach in the study of international relations].Scientific works. Politology, Vol 228, № 216. Retrieved from: http://politics.chdu.edu.ua/article/view/27684/24799

${ }^{16}$ Feola, G., Jaworska, S. (2019) One transition, many transitions? A corpus-based study of societal sustainability transition discourses in four civil society's proposals. Sustainability Science, 14, pp. 1643-1656. DOI https://doi.org/10.1007/s11625-018-0631-9

${ }^{17}$ Way, L. A. (2004). The Sources and Dynamics of Competitive Authoritarianism in Ukraine. Journal of Communist Studies and Transition Politics, 20:1, pp. 143-161. DOI:10.1080/13523270410001687145 
popular term in political, media, and scientific discourse. The idea of transition as a difficult and long-running process of achieving capitalism and consolidated democracy remains attractive to political elites and experts. The impact of civil society on transition will be limited as long as civil society is not actively involved in forming the political discourse. Nowadays, the political discourse in Ukraine can be called "oligarchic", because it is formed mainly by mass media belonging to oligarchic groups ${ }^{18}$. The political discourse is anti-civil (political discourse is actually uncivil), which means that it does not facilitate the transition from authoritarianism to democracy.

The country's political regime is facing difficult challenges, taking on the challenges of both anarchy and authoritarianism. These threats are easily identified in the conditions of occupation of Crimea, armed conflict and the presence of temporarily uncontrolled territories ${ }^{19}$.

The main danger of the political discourse of a transitional society is expressed in the title of this article. It lies in the squeeze of political discourse between two utopias. It is difficult to move to a real democracy from the utopias of anarchy and authoritarianism. The promise of rapid and understandable human happiness makes them utopias. In the case of authoritarianism, it is because of the dissolution of individuality in the group and the grandeur of the state, and in the case of anarchy, the rejection of any moral norms, social additions and collective interests. "Utopia and anarchy are not irreconcilable ideas, but are consistent only when "utopia points to an ideal life without becoming a plan, that is, a lifeless machine applied to living matter". As a nonplanned ideal, utopia "truly becomes the realisation of progress"... And the reason is that anarchists viewed 'the world of anarchy' as 'a spontaneous creation of the free, untrammelled spirit of the men ... not fettered to any previously formulated plans or dogmas'. A blueprint of anarchy, they continue, 'would be self-contradictory, internally inconsistent, and anathema to anarchists" (Kinna, R. (2005)) $)^{20}$.

In the political discourse of a transitional society, Stalinist totalitarianism and Brezhnev's authoritarianism are identified as starting points of transition. These are political regimes that have been abandoned and repelled in search of Brave New World (Huxley, A.(1969)) ${ }^{21}$. Instead, the purpose of transition has

${ }^{18}$ Komu nalezhatj najbiljshi ZMI v Ukrajini: opublikovano cikavu infoghrafiku [Who to find the most serious ZMI in Ukraine: a published infographi]. Apostrophe Retrieved from: https://apostrophe.ua/ua/news/society/2019-04-03/komu-prinadlejat-krupneyshie-smi-v-ukraineopublikovana-interesnaya-infografika/159113

19 Analytical report on the results of the research carried out among the population of temporarily uncontrolled territories. Ukrainian Institute of the Future. Retrieved from: https://www.uifuture.org/en/publications/reports/24339dumky/ta/nastroi/jyteliv/okupovanych/terytoriy

${ }^{20}$ Kinna, R. (2005). Anarchism: A Beginner's Guide, Oxford,180 p.

${ }^{21}$ Huxley, A.(1969). Brave New World. New York: Harper Brothers. 
become debatable. It is formulated as a choice between two utopias: authoritarian and anarchist. The role of political discourse is to justify the transit from the authoritarian system to the western forms of democratic governance, from Soviet socialism to capitalism. Discourse becomes one of the key elements in the transitional process, the construction of its purpose, stages, objects and subjects. The history of transition in Ukraine proves that discourse is initially formed, which, thanks to the borrowings from the discourse of Western democracies, substantiates the need for the introduction of certain institutions. In the process of implementation in the specific circumstances of post-Soviet society, these ideas are distorted and expressed in the creation of simulative, imperfect, but quite realistic bodies, structures and organizations. Their activities have little in common with the patterns of democratic discourse, but effectively protect the selfish interests of individual players (oligarchs and bureaucrats).

The changes in political practices affect institutional interaction and the combinations of elements of discourse in practices: "Social change in countries, organisations etc is often initiated with new discourses. This operates through a dissemination across structural and scalar boundaries which 'recontextualizes' new discourses. These may be enacted as new ways of (inter)acting including genres, inculcated as new ways of being including styles, as well as materialized in eg new ways of structuring space. Thus liberal and neoliberal discourses have been recontextualized in 'transitional' countries in CEE, and to varying degrees enacted in new ways of (inter)acting (eg in government, including government addressing and interacting with citizens as consumers), inculcated in new ways of being (eg people adopting the lifestyles and identities of consumers), and materialized in such new constructions of space as the "shopping mall" (Fairclough, N. (2005)) ${ }^{22}$.

Contemporary political discourse in Ukraine is being formed in the conditions of political mediatization. Under the influence of mediatization, political discourse is changing, and debate is turning into a television show. It is about the emergence of a new ruling class of media owners, editors, and authors -mediacracy: "The technological capabilities of the media and its outreach make it possible to speak of the emergence of a new actor in politics - a mediacracy that promotes the politicization of politics through the subordination of the political agenda to the criteria of format and rating of the media" (Yakovlev, D.V. (2014) ${ }^{23}$. And this, according to T. Snyder, is a threat

${ }^{22}$ Fairclough, N. (2005). Discourse in processes of social change: "Transition" in central and eastern Europe. British and American Studies, № 11, pp. 9-34.

${ }^{23}$ Yakovlev, D.V. (2014). Oponenty demokratiji: rolj "partiji vlady" ta mediakratiji u postradjansjkij polityci [Opponents of Democracy: The Role of the "Party of Power" and the Mediaocracy in Post-Soviet Politics]. Young scientist, vol. 9, pp. 198-201. Retrieved from: http://molodyvcheny.in.ua/files/journal/2014/9/49.pdf 
that promotes authoritarianism: "The effort to define the shape and significance of events requires words and concepts that elude us when we are entranced by visual stimuli. Watching televised news is sometimes little more than looking at someone who is also looking at a picture. We take this collective trance to be normal. We have slowly fallen into in" (Snyder T. (2017)) $)^{24}$. For transitional societies, the dynamic expansion of such a relatively new phenomenon as media policy poses particular threats. The Soviet "... individual who emerged from the vestige of "real communism" with censorship, an"iron veil", a black-and-white screen and the only candidate from the bloc of "communists and non-party" enters the dynamic global information world, where the biggest challenge for a choice is not the lack of information, but its redundancy. The role of the media, which, apart from the traditional functions, virtualize the political space, create "hyper-reality", and turn politics into a media process, is changing" (Yakovlev, D.V. (2014)) ${ }^{25}$.

An appropriate discourse order is created, which differs from both the Soviet and the democratic ones in styles and genres. It in characterized by new relationships between politics and the media, the creation of information networks, etc. However, it is not the voice of civil society. This is evident in the following.

Firstly, this is evident in the restoration of a particular type of political discourse in the post-Soviet countries - the discourse of propaganda in the media. It most clearly shows the trace of Soviet authoritarian discourse. In the mirror of political propaganda, the trend of the mediatization of politics is combined with manipulation, distortion of facts, outright lies. The discourse of propaganda may be rating, but it is uncivil. It spoils everything it touches: "In political discourse and especially in the discourse of propaganda the profanation of philosophical teachings is generally carried out, which inevitably leads to their distortion. In order to deconstruct this profanation, it is necessary to analyse the worldview bases of consciousness of the subjects of contemporary political and propaganda struggle (Eremenko A., Yakovlev D. (2019)) ${ }^{26}$.

${ }^{24}$ Snyder T. (2017). On Tyranny: Twenty Lessons from the Twentieth Century. New York: Tim Duggan Books, $126 \mathrm{p}$.

${ }^{25}$ Yakovlev, D.V. (2014). Oponenty demokratiji: rolj "partiji vlady" ta mediakratiji u postradjansjkij polityci [Opponents of Democracy: The Role of the "Party of Power" and the Mediaocracy in Post-Soviet Politics]. Young scientist, vol. 9, pp. 198-201. Retrieved from: http://molodyvcheny.in.ua/files/journal/2014/9/49.pdf

${ }^{26}$ Eremenko A., Yakovlev D. (2019). "My dialektiku uchili ne po Gegelyu". Filosofiya v zerkale politicheskoy propagandy: popytka antropologicheskogo podkhoda ["We studied dialectics not according to Hegel". The philosophy in the mirror of political propaganda: an attempt to the anthropological approach] Current problems of philosophy and sociology, no. 24, pp. 10-23. https://doi.org/10.32837/apfs.v0i24.885 
Secondly, political analytics is presented in the genre of an interview, complex economic and political ones are presented in a simplified way in order to promote content and increase the rating of programmes. Politicians and civil servants adopt the style of clothing and behaviour of show stars, actors and turn themselves into celebrities.

Thirdly, this is evident in the focus of political discourse on the process of transition (the imperfections of existing political institutions, the need to "improve", media scandals surrounding individual politicians) and the use of certain topics and cliches borrowed from the discourse of democratic countries for manipulation. The interaction of political discourse with other discourses, as well as with non-discursive aspects of the process of "transition", requires rethinking from the standpoint of the interdisciplinary approach of the phenomenon of "transition" and "a transitional society" to determine the specificity of Ukrainian transition, its perception of the community. Identifying the elements of discourse that represent the continuity of particular discursive practices or indicate that there are some political changes requires additional research.

In the contemporary agenda setting, a new research programme is being formed. It is aimed at exploring the discourse of transitional societies. Regardless of political discourse, the essence of transition cannot be covered. Political discourse shapes public opinion about the purpose of transition and its necessity. Furthermore, it offers alternatives to a political choice and creates new images, identities, and patterns of behaviour. The role of political discourse is extremely important not only in the post-communist context but also in the global one: "Discourse is central in generating new and alternative imaginaries of the future and in making previously unthinkable alternatives plausible and conceivable... A language of connection and regeneration has become prominent in a range of transition discourses that have emerged from the civil society worldwide... Discourses also matter in framing and identity making and have been shown to influence the level of engagement in collective mobilization for sustainability, household or individual proenvironmental action, as well as the establishment of coalitions for or against change. Along the same lines, Loorbach et al. (2016) highlight the importance of discursive framing as social construction of sustainability transitions in that it "can give rise to the potential for (seemingly) short-term pressures to become game changers", and for combinations of specific events to "help to orient, legitimize, guide, and accelerate deep changes in society" (Feola, G., Jaworska, S. (2019)) $)^{27}$.

${ }^{27}$ Feola, G., Jaworska, S. (2019) One transition, many transitions? A corpus-based study of societal sustainability transition discourses in four civil society's proposals. Sustainability Science, 14, pp. 1643-1656. DOI https://doi.org/10.1007/s11625-018-0631-9 


\section{Peculiarities of Ukrainian Transition in Mass Media Materials}

For Ukraine, which has been going through a stage of political transformation for over thirty years, the problem of determining the nature of transition and its peculiarities is of utmost importance. We are fully concerned with the question: "What is a transition?' This question is pertinent in understanding the motivation amongst scientists, policy makers, practitioners, business actors and community groups in transitioning society towards sustainability" (Silva, A., Stocker, L. (2018)) $)^{28}$.

After the collapse of the Soviet Union, the political discourse changed beyond recognition: the obsessions of Marxism-Leninism and the Soviet political "newspeak" disappeared almost entirely, and Gorbachev's "perestroika", "glasnost" and "new thinking" opened the floodgates (often uncritical and sometimes just meaningless) from Western discourse (Eremenko A., Yakovlev D. $(2019))^{29}$.

In the discourse of political science, modern Ukrainian society is called “divided" (Walker E. W. (2014) ${ }^{30}$; Riabchuk M. (2015) $)^{31}$ and the political regime is "hybrid" (Yakovlev D. (2015)) ${ }^{32}$.

The discourse of transition is presented in Ukraine in the mass media, scientific research, government documents, legal acts, speeches by politicians, political party programs, etc. In the Ukrainian media, considerable attention is paid to the nature of the political regime and the problem of transition. In the genres of analytical articles, commentaries, blogs and interviews, the issues of transition are regularly covered in the newspapers "Dzerkalo Tyzhna" (https://dt.ua/), and "Den" (https://day.kyiv.ua/en), the online edition of "Ukrainska Pravda" (https://www.pravda.com.ua/). Among the Englishlanguage sources, there is "KyivPost", the only English-language newspaper in

${ }^{28}$ Silva, A., Stocker, L. (2018). What is a transition? Exploring visual and textual definitions among sustainability transition networks. Global Environmental Change, vol. 50, pp. 60-74. Retrieved from: https://doi.org/10.1016/j.gloenvcha.2018.02.003

${ }^{29}$ Eremenko A., Yakovlev D. (2019). "My dialektiku uchili ne po Gegelyu". Filosofiya v zerkale politicheskoy propagandy: popytka antropologicheskogo podkhoda ["We studied dialectics not according to Hegel". The philosophy in the mirror of political propaganda: an attempt to the anthropological approach] Current problems of philosophy and sociology, no. 24, pp. 10-23. https://doi.org/10.32837/apfs.v0i24.885

${ }^{30}$ Walker, E. W. (2014). Ukraine: Divided Nation, Divided State. Eurasian Geopolitics. Retrieved from: http://eurasiangeopolitics.com/2014/03/14/ukraine-divided-nation-divided-state

31 Riabchuk M. (2015) "Two Ukraine's' Reconsidered" The End of Ukrainian Ambivalence? Studies in Ethnicity and Nationalism, vol. 15, no. 1, pp. 138-156.

${ }^{32}$ Yakovlev D. (2015) Political choice of Ukraine: alternatives to the Grand Duke and restriction of the last secretary general. Proceedings of the Social and political configurations of Modernity: Political Power in Ukraine and in the World: Materials of the 4th International Scientific and Practical Conference (Ukraine Kyiv, June 3-4, 2015) (eds G. Derlugyan, A.A. Melnichenko, P. V. Kutuev, A. A. Migalush), Kyiv: Talcom, pp. 39-41. 
Ukraine (https://www.kyivpost.com/), and reviews and analytics of the journal "Krytyka" (https://krytyka.com/en) where special attention is paid to understanding the essence of the post-Soviet transition, and all articles are offered on the website in both Ukrainian and English. This study will provide some examples and quotations that represent the distinctive themes and features of contemporary political discourse.

One of the main features of political discourse is its prevalence (it is most widely broadcast by the mass media) and the focus of information on the mass audience. In political discourse, there is a dialectical connection between the individual and the collective. Owing to the speed of information transmission, the mass character and the prevalence, individual opinions become collective ones and influence public opinions through thought leaders. Through the prism of the statements of individual politicians, journalists and experts, one can trace the general trends in the development of the political discourse of a transitional society. Such trends include overcoming the Soviet ambiguity of false bottom when one thing is publicly stated, and another is meant: "until recently ... the war is called "anti-terrorist operation", the political crisis is called "decentralization", and the capitulation is called "special status" (Pokaljchuk, O. (2015) $)^{33}$. The current political discourse in Ukraine O. Pokalchuk calls "authoritarian pluralism" in the article "Ynakodeistvye" (Pokaljchuk, O. (2015) $)^{34}$. This correlates with M. Minakov's definition of the state of Ukrainian transitional society as "competitive authoritarianism" (Minakov, M. (2016) $)^{35}$. In agreement with this, it should be noted that in the context of pluralism and the constant fierce struggle for limited resources in the transitional society, there is a growing risk of populism, from which there is one step both to authoritarianism and, taking into an account the division of the Ukrainian society, to anarchy. One of the leading Ukrainian intellectuals I. Dziuba sends an appeal which is aimed at the criticism of populist rhetoric, which simplifies all problems of a transitional society: “... a naive or even primitive view explains all troubles with incompetence (options - with unscrupulousness, irresponsibility and corruption) of ministers. Ministers are changing, however, troubles remain. The incompetent ones (corruptive ones, etc.) are replaced by those who reproached them for incompetence (corruption, etc.), and then the latter ones are accused of having a complete list of the same

${ }^{33}$ Pokaljchuk, O. (2015) Inakodija [Inakodiya]. Dzerkalo tyzhnja, № 43. Retrieved from: https://dt.ua/socium/inakodiya-_.html

${ }^{34}$ Pokaljchuk, O. (2015) Inakodija [Inakodiya]. Dzerkalo tyzhnja, № 43. Retrieved from: https://dt.ua/socium/inakodiya-_.html

${ }^{35}$ Minakov, M. (2016). A Decisive Turn? Risks for Ukrainian Democracy After the Euromaidan, In: Carnegie Regional Insight, Carnegie Endowment for International Peace, February 3. 
sins. And there is no end to this carousel" (Savenko, O. (2015)) $)^{36}$. Attention is repeatedly paid to overcoming manipulations and limiting the discourse of propaganda. To this end, the need to appeal to scientific knowledge, scientists, and intellectuals is reasonably stated. The role of science, scholars, and intellectuals are rarely mentioned in the discourse of a transitional society. Science is not identified as a source of knowledge and information to help find a way out of the crisis. This also applies to the materials of research, where the emphasis is placed on the need to restore authority to scholars and intellectuals. The following quotations are illustrating these principles:

1. Emphasis on the problem of a new social contract and the “... creation of an educational system for the discovery and development of human talents... the formation, support, propaganda and strengthening of the state ideology based on universal human values through the development of philosophy, culture, education and civil public media" (Stavnijchuk, M. $(2016))^{37}$;

2. "There are many intellectuals in Ukraine, but the national intellectual society has not been formed. Squabbling, politicking, narcissism, petty local selfishness and "it is neither my headache nor my piece of cake". The Internet crowd of the blogosphere has proven to be stronger and more influential than the most advanced and educated authority whether it is a scholar, a teacher, a doctor or a social activist." (Jermolajev A. (2017)) $)^{38}$;

3 . In the context of "hybrid war", it is very important to create "... a kind of "scientific hub", a certain point of application of efforts and knowledge to unite the efforts of scholars, representatives of state structures and bodies of the security and defence sector, civil society to provide the country's militarypolitical leaders with a strategic way out of the crisis" (Ghorbulin V. (2017)) ; $^{39}$;

4. The role of university historians as representatives of the class of "public intellectuals" in the transitional society is as follows: "As far as

${ }^{36}$ Savenko, O. (2015). Ivan Dzjuba: 'Mozhe, same teper formujetjsja politychna ukrajinsjka nacija, pro jaku vesj chas ghovorylosja': interv'ju [Ivan Dzuba: 'Maybe this is the moment the political Ukrainian nation is being formed, which has been talked about all the time': interview]. Dzerkalo tyzhnja. № 18. Retrieved from: https://dt.ua/personalities/ivan-dzyuba-mozhesame-teper-formuyetsya-politichnaukrayinska-naciya-pro-yaku-ves-chas-govorilosya-.html

${ }^{37}$ Stavnijchuk, M. (2016). Dvi Ukrajiny. Pole boju - Konstytucija [Two Ukraine. The battlefield is the Constitution]. Dzerkalo tyzhnja, № 23. Retrieved from: https:/dt.ua/article/ print/internal/dviukrayini-pole-boyu-konstituciya-ukrayini-sogodni-potribni-principovo-nova-

konstituciyanovi-gorizonti-suspilnogo-rozvitku-i-pravovih-oriyentiriv

${ }^{38}$ Jermolajev A. (2017). Majbutnje minlyve. Bo - zminjuvane [The future is changeable. Because it is changeable]. Dzerkalo tyzhnja, № 3. Retrieved from: https://dt.ua/article/print/ internal/maybutnye-minlive-bo-zminyuvane-_.htm

${ }^{39}$ Ghorbulin V. (2017). '2017-j: dali bude...'Je ['2017: will be ...'] Dzerkalo tyzhnja, № 24. Retrieved from: https://dt.ua/article/print/internal/2017-y-dali-bude-cinnisni-resursi-viyniimiru-ukrayinskiy-format-_.html 
academic historians are concerned, their role might be the following. Because many of the problems and challenges faced by societies have important historical and comparative dimensions, many of them unknown to politicians and ordinary citizens, historians might focus on demonstrating these broader contexts. From this perspective, the main task of historians is not to make correct predictions about future developments or to find ready-made solutions for current problems, but to formulate new, more appropriate questions that enable the public to expand their horizons and discover other, possibly more productive, ways of discussing problems" (Sklokin V. (2015)) ${ }^{40}$;

5. It is pointless to fight with a lie by using a "counter-lie" (an "alternative" lie). The only alternative to lying is reliable information. Unfortunately, we often neither see nor hear it ... And do we have an adequate idea of the social composition of the supporters of "separatism", their ideology and argumentation? There are not only bandits and alcoholics and the $\mathrm{H}$ do not use only Russian weapons. And the polemic with them should be conducted not only by weapons. You need to know them better and their motivation. Then it will be possible to respond to false propaganda with a word of truth. Up to now, we do not always succeed" (Savenko, O. (2015)) ${ }^{41}$.

Controversial topics for the political discourse of the transitional society have become the problem of changes to the Constitution ${ }^{42}$, language policy ${ }^{43}$, overcoming Corruption (Ordukhanyan, E. (2019)) $)^{44}$.

It should also be noted the process of "decommunization", which started with the adoption of the Law of Ukraine "On condemning the communist and national-socialist (Nazi) totalitarian regimes in Ukraine and prohibiting the propaganda of their symbolism" of April 9, 2015 ${ }^{45}$. The discussion on "decommunization" was started by the magazine "Krytyka" 46 .

${ }^{40}$ Sklokin V. (2015). Turning Public: Historians and Public Intellectual Activity in PostSoviet Ukraine, Krytyka. Retrieved from: https://krytyka.com/en/articles/turning-public-historiansand-public-intellectual-activity-post-soviet-ukraine?domain_switch=full

${ }^{41}$ Savenko, O. (2015). Ivan Dzjuba: 'Mozhe, same teper formujetjsja politychna ukrajinsjka nacija, pro jaku vesj chas ghovorylosja': interv'ju [Ivan Dzuba: 'Maybe this is the moment the political Ukrainian nation is being formed, which has been talked about all the time': interview]. Dzerkalo tyzhnja. № 18. Retrieved from: https://dt.ua/personalities/ivan-dzyuba-mozhesame-teper-formuyetsya-politichnaukrayinska-naciya-pro-yaku-ves-chas-govorilosya-.html

${ }^{42}$ Experts: Constitutional changes do not threaten national sovereignty). Retrieved from: https://www.kyivpost.com/article/content/ukraine-politics/experts-constitutional-changes-dontthreaten-national-sovereignty-397201.html, Published Sept. 4, 2015 at 5:35 pm)

43 Ukraine says new law does not restrict minority language rights By Veronika Melkozerova 29, 2017, Retrieved from: https://www.kyivpost.com/ukraine-politics/ukraineclarifies-new-education-bill-language-norm-enraged-hungary-romania-russia.html

${ }^{44}$ Ordukhanyan, E. (2019). A comparative analysis of theoretical and methodological foundations of political culture. Wisdom, (1 (12)), 38-48.

45 Pro zasudzhennja komunistychnogho ta nacional-socialistychnogho (nacystsjkogho) totalitarnykh rezhymiv $\mathrm{v}$ Ukrajini ta zaboronu propaghandy jikhnjoji symvoliky [On condemning 
A separate line of political discourse is devoted to the problem of occupation of Crimea, the armed conflict in Eastern Ukraine, its causes and consequences $^{47}$, conceptualization (Carroll J. (2015)) ${ }^{48}$, finding the ways out of the crisis ${ }^{49}$.

In the context of the problems of the transit society, political discourse emphasizes the interaction and correlation of democratization processes, ensuring the rule of law and fundamental freedoms of citizens and enhancing the country's defence capacity. To some extent, these tasks are contradictory to each other, but the rights and freedoms of citizens should be restricted, and the level of civil society's activity should not be reduced to increase its defence capacity. On the contrary, in an armed conflict, it is important to promote the voice of civil society in political discourse. The task of civil society in political discourse is to become the antithesis of propaganda.

\section{CONCLUSIONS}

This article has offered a comprehensive review of the examples of the contemporary political discourse of a transitional society. Two threats to a transitional society that relate to the status and the prospects of political discourse have been identified. The following challenges for the political discourse of a transitional society have been studied: 1) anarchy; 2) authoritarianism. They have been identified as the utopias that appeal to a mass consumer and hinder the formation of democratic political discourse, and therefore the transition to a consolidated democracy. The focus on the mass audience, manipulation by the oligarchic mass media, ambiguity are also the features of modern political discourse. The danger of ignoring scientific arguments and reducing attention to the views of scientists and intellectuals have been noted, the examples to illustrate this danger have been provided.

The main controversial topics of the current political discourse of the transitional society in Ukraine are 1) democratization; 2) armed conflict in

the communist and national-socialist (Nazi) totalitarian regimes in Ukraine and banning the propaganda of their symbolism] Law of Ukraine on April 9, 2015 № 317-VIII Retrieved from: https://zakon.rada.gov.ua/laws/show/317-19?lang=en

${ }^{46}$ Submit your opinion piece on 'decommunization' in Ukraine Krytyka, April, 2015. Retrieved from: https://krytyka.com/en/articles/submit-your-opinion-piece-decommunization-ukraine

${ }^{47}$ Geopolitics Against Democracy: Ukraine's Democratization and Russian Great Power Aspirations. Krytyka, June, 2018. Retrieved from: https://krytyka.com/en/ukraine-and-donbas-canwe-be-together-again/articles/geopolitics-against-democracy-ukraines

${ }^{48}$ Carroll J. (2015). Conceptualizing the War in Donbas Krytyka, October, 2015 Retrieved from: https://krytyka.com/en/community/blogs/conceptualizing-war-donbas

${ }^{49}$ Why the Fight for the Hearts and Minds of People in Donbas Remains Urgent Today. Krytyka, November, 2019. Retrieved from: https://krytyka.com / en / ukraine-and-donbas-can-webe-together-again / articles / why-fight-hearts-and-minds-people-donbas 
Eastern Ukraine and occupation of Crimea; 3) constitutional process; 4) language policy; 5) counteracting political corruption; 6) decommunization.

The emphasis has been placed on the uncivil status of contemporary political discourse. This means that it is formed by the influence of the oligarchic masses of the media. The voice of civil society is not heard. The threat of mediatization of politics and the effective counteraction to it (rationalization of political argumentation) have been described. The main point is that the lack of activity of civil society leads to the manipulation and the distortion of political discourse by the oligarchic mass media. As a result, the discourse of propaganda is formed. It is aimed at dividing society, creating the "image of an enemy", hate speech instead of political dialogue.

This is especially dangerous in the context of armed conflict, when the offensive on freedom of speech, the diminishing influence of civil society, in particular, in the formation of political discourse, explains the need to increase defence capabilities.

\section{SUMMARY}

The current political discourse in Ukraine is defined as "uncivil". It is determined that civil society does not sufficiently influence the formation of political discourse. Utopias are a major threat to the political discourse of a transitional society. They have a strong influence on public opinion and are therefore used to gain power. Utopias are expressed in the form of anarchy and authoritarianism. Utopias are exacerbated by political propaganda which is broadcast by the oligarchic mass media. The armed conflict in the East of Ukraine and the occupation of Crimea, constitutional process, language policy, counteraction to political corruption, etc. are among the main topics of political discourse that require the greater activity of civil society as an alternative to the "utopia" of the discourse of the oligarchic mass media.

\section{REFERENCES}

1. Analytical report on the results of the research carried out among the population of temporarily uncontrolled territories. Ukrainian Institute of the Future. Retrieved from: https://www.uifuture.org/en/publications/ reports/24339dumky/ta/nastroi/jyteliv/okupovanych/terytoriy (accessed 11 February 2020)

2. Carroll J. (2015) Conceptualizing the War in Donbas Krytyka, October, 2015 Retrieved from: https://krytyka.com/en/community/blogs/ conceptualizing-war-donbas (accessed 11 February 2020)

3. Dahl, R. A. (2005). Who Governs? Democracy and Power in an American City (2nd ed.). New Haven and London: Yale University Press, $355 \mathrm{p}$. 
4. Eremenko A., Yakovlev D. (2019). "My dialektiku uchili ne po Gegelyu". Filosofiya v zerkale politicheskoy propagandy: popytka antropologicheskogo podkhoda ["We studied dialectics not according to Hegel". The philosophy in the mirror of political propaganda: an attempt to the anthropological approach] Current problems of philosophy and sociology, no. 24, pp. 10-23. https://doi.org/10.32837/apfs.v0i24.885 (accessed 11 February 2020)

5. Experts: Constitutional changes do not threaten national sovereignty). Retrieved from: https://www.kyivpost.com/article/content/ ukraine-politics/experts-constitutional-changes-dont-threaten-nationalsovereignty-397201.html, Published Sept. 4, 2015 at 5:35 pm) (accessed 11 February 2020)

6. Fairclough, N. (2000). Discourse, social theory, and social research: The discourse of welfare reform. Journal of Sociolinguistics, 4, pp. 163-195. Doi: 10.1111/1467-9481.00110

7. Fairclough, N. (2005). Discourse in processes of social change: "Transition" in central and eastern Europe. British and American Studies, № 11, pp. 9-34.

8. Feola, G., Jaworska, S. (2019) One transition, many transitions? A corpus-based study of societal sustainability transition discourses in four civil society's proposals. Sustainability Science, 14, pp. 1643-1656. DOI https://doi.org/10.1007/s11625-018-0631-9

9. Geopolitics Against Democracy: Ukraine's Democratization and Russian Great Power Aspirations. Krytyka, June, 2018. Retrieved from: https://krytyka.com/en/ukraine-and-donbas-can-we-be-together-again/articles/ geopolitics-against-democracy-ukraines (accessed 11 February 2020)

10. Ghorbulin V. (2017). '2017-j: dali bude...'Je ['2017: will be ...'] Dzerkalo tyzhnja, № 24. Retrieved from: https://dt.ua/article/print/internal/ 2017-y-dali-bude-cinnisni-resursi-viyni-imiru-ukrayinskiy-format-_.html (accessed 11 February 2020)

11. Holland, H. M. (1963). Who governs? democracy and power in an american city By Robert A. Dahl 355 pp. New Haven and London: Yale University Press, 1961. Social Forces, vol. 41, pp. 322-323. Retrieved from: https://doi.org/10.2307/2573188 (accessed 11 February 2020)

12. Huxley, A. (1969). Brave New World. New York: Harper Brothers.

13. Jermolajev A. (2017) Majbutnje minlyve. Bo - zminjuvane [The future is changeable. Because it is changeable]. Dzerkalo tyzhnja, № 3. Retrieved from: https://dt.ua/article/print/internal/maybutnye-minlive-bozminyuvane-_.htm (accessed 11 February 2020) 
14. Kinna, R. (2009)Anarchism and the Politics of Utopia, In Davis, L., Kinna, R. Anarchism and Utopianism, Manchester: Manchester University Press, pp. 221-40.

15. Kinna, R. (2005). Anarchism: A Beginner's Guide, Oxford, 180 p.

16. Komu nalezhatj najbiljshi ZMI v Ukrajini: opublikovano cikavu infoghrafiku [Who to find the most serious ZMI in Ukraine: a published infographi]. Apostrophe Retrieved from: https://apostrophe.ua/ua/news/ society/2019-04-03/komu-prinadlejat-krupneyshie-smi-v-ukraineopublikovana-interesnaya-infografika/159113 (accessed 11 February 2020)

17. Koopmans, R., \& Statham, P. (Eds.) (2010). The Making of a European Public Sphere. Media Discourse and Political Contention. Communication, Society and Politics. Cambridge: Cambridge University Press, 335 p. doi:10.1017/CBO9780511761010 (accessed 11 February 2020)

18. Minakov, M. (2016). A Decisive Turn? Risks for Ukrainian Democracy After the Euromaidan, In: Carnegie Regional Insight, Carnegie Endowment for International Peace, February 3.

19. Oberkovych, S.( 2017) As 2017 wraps up, Ukraine remains a 'land of opportunity' By Brian Bonner. Retrieved from: https://www.kyivpost.com/ business/sergiy-oberkovych-2017-wraps-ukraine-remains-land-opportunities.htm (accessed 11 February 2020)

20. Ordukhanyan, E. (2019). A comparative analysis of theoretical and methodological foundations of political culture. Wisdom, (1 (12)), 38-48.

21. Pokaljchuk, O. (2015) Inakodija [Inakodiya]. Dzerkalo tyzhnja, № 43. Retrieved from: https://dt.ua/socium/inakodiya-_.html (accessed 11 February 2020)

22. Pro zasudzhennja komunistychnogho ta nacional-socialistychnogho (nacystsjkogho) totalitarnykh rezhymiv $\mathrm{v}$ Ukrajini ta zaboronu propaghandy jikhnjoji symvoliky [On condemning the communist and national-socialist (Nazi) totalitarian regimes in Ukraine and banning the propaganda of their symbolism] Law of Ukraine on April 9, 2015 № 317-VIII Retrieved from: https://zakon.rada.gov.ua/laws/show/317-19?lang=en (accessed 11 February 2020)

23. Riabchuk M. (2015) “Two Ukraine's' Reconsidered” The End of Ukrainian Ambivalence? Studies in Ethnicity and Nationalism, vol. 15, no. 1, pp. 138-156.

24. Savenko, O. (2015) Ivan Dzjuba: 'Mozhe, same teper formujetjsja politychna ukrajinsjka nacija, pro jaku vesj chas ghovorylosja': interv'ju [Ivan Dzuba: 'Maybe this is the moment the political Ukrainian nation is being formed, which has been talked about all the time': interview]. Dzerkalo tyzhnja. № 18. Retrieved from: https://dt.ua/personalities/ivan-dzyuba-mozhe-same- 
teper-formuyetsya-politichnaukrayinska-naciya-pro-yaku-ves-chas-govorilosya.html (accessed 11 February 2020)

25. Silva, A., Stocker, L. (2018). What is a transition? Exploring visual and textual definitions among sustainability transition networks. Global Environmental Change, vol. 50, pp. 60-74. Retrieved from: https://doi.org/ 10.1016/j.gloenvcha.2018.02.003(accessed 11 February 2020)

26. Sklokin V. (2015). Turning Public: Historians and Public Intellectual Activity in Post-Soviet Ukraine, Krytyka. Retrieved from: https://krytyka.com/ en/articles/turning-public-historians-and-public-intellectual-activity-post-sovietukraine?domain_switch=full (accessed 11 February 2020)

27. Snyder T. (2017) On Tyranny: Twenty Lessons from the Twentieth Century. New York: Tim Duggan Books, 126 p.

28. Stavnijchuk, M. (2016) Dvi Ukrajiny. Pole boju - Konstytucija [Two Ukraine. The battlefield is the Constitution]. Dzerkalo tyzhnja, № 23. Retrieved from: https://dt.ua/article/print/internal/dviukrayini-pole-boyu-konstituciyaukrayini-sogodni-potribni-principovo-nova-konstituciyanovi-gorizontisuspilnogo-rozvitku-i-pravovih-oriyentiriv (accessed 11 February 2020)

29. Submit your opinion piece on 'decommunization' in Ukraine Krytyka, April, 2015. Retrieved from: https://krytyka.com/en/articles/submityour-opinion-piece-decommunization-ukraine (accessed 11 February 2020)

30. Ukraine says new law does not restrict minority language rights By Veronika Melkozerova 29, 2017., Retrieved from: https://www.kyivpost.com/ ukraine-politics/ukraine-clarifies-new-education-bill-language-norm-enragedhungary-romania-russia.html (accessed 11 February 2020)

31. Van Dijk, T.A. (2006). Ideological discourse analysis. Journal of Political Ideologies, 11(2), pp.115-140. DOI: 10.1080/13569310600687908

32. Walker, E. W. (2014). Ukraine: Divided Nation, Divided State. Eurasian Geopolitics. Retrieved from: http://eurasiangeopolitics.com/2014/ 03/14/ukraine-divided-nation-divided-state (accessed 11 February 2020)

33. Way, L. A. (2004). The Sources and Dynamics of Competitive Authoritarianism in Ukraine. Journal of Communist Studies and Transition Politics, 20:1, pp.143-161. DOI:10.1080/13523270410001687145

34. Why the Fight for the Hearts and Minds of People in Donbas Remains Urgent Today. Krytyka, November, 2019. Retrieved from: https://krytyka.com/en/ukraine-and-donbas-can-we-be-together-again/articles/ why-fight-hearts-and-minds-people-donbas (accessed 11 February 2020)

35. Wodak, R., De Cillia, R., Reisigl, M., Liebhart, K., Hirsch, A., Mitten, R., \& Unger, J. (2009). The Discursive Construction of National Identity (2nd ed.). Edinburgh: Edinburgh University, 288 p. 
36. Wodak, R., \& Meyer, M. (2001). Critical discourse analysis: History, agenda, theory and methodology, In R. Wodak \& M. Meyer (Eds.), CDA Methods (pp. 2-21). London: Sage.

37. Yakovlev D. (2015) Political choice of Ukraine: alternatives to the Grand Duke and restriction of the last secretary general. Proceedings of the Social and political configurations of Modernity: Political Power in Ukraine and in the World: Materials of the 4th International Scientific and Practical Conference (Ukraine Kyiv, June 3-4, 2015) (eds G. Derlugyan, A.A. Melnichenko, P. V. Kutuev, A. A. Migalush), Kyiv: Talcom, pp. 39-41.

38. Yakovlev, D.V. (2012) Mystectvo polityky z tochky zoru teoriji racionaljnogho vyboru [Art of politics in terms of the theory of rational choice] Proceedings of the Legal life of modern Ukraine: Mater., International Scientific Conf. Prof. Off-staff (Ukraine, Odesa, April 20-21, 2012) (ed. V.M. Dremin), Odessa: Phoenix, Vol. 1, pp. 211-213.

39. Yakovlev, D.V. (2014) Oponenty demokratiji: rolj "partiji vlady" ta mediakratiji u postradjansjkij polityci [Opponents of Democracy: The Role of the "Party of Power" and the Mediaocracy in Post-Soviet Politics]. Young scientist, vol. 9, pp. 198-201. Retrieved from: http://molodyvcheny.in.ua/ files/journal/2014/9/49.pdf (accessed 11 February 2020)

40. Yakovlev, D.V. (2014) Pidkhid racionaljnogho vyboru v doslidzhenni mizhnarodnykh vidnosyn [Rational choice approach in the study of international relations]. Scientific works. Politology, Vol 228, № 216. Retrieved from: http://politics.chdu.edu.ua/article/view/27684/24799 (accessed 11 February 2020)

\section{Information about the authors:} Yakovlev D. V., Prof. dr hab.,

Dean of the Faculty of Psychology, Political Science and Sociology, National University Odessa Law Academy 23, Fontanska str., Odessa, 65009, Ukraine ORCID ID: orcid.org/0000-0003-2828-4669

Yeremenko O. M., Prof. dr hab., Head of the Department of Philosophy, National University Odessa Law Academy 23, Fontanska str., Odessa, 65009, Ukraine ORCID ID: orcid.org/0000-0002-2922-0643 
NOTES 
NOTES 
Publishing house "Liha-Pres"

9 Kastelivka str., Lviv, 79012, Ukraine

44 Lubicka str., Torun, 87-100, Poland

Printed by the publishing house "Liha-Pres"

Passed for printing: August 31, 2020.

A run of 150 copies. 